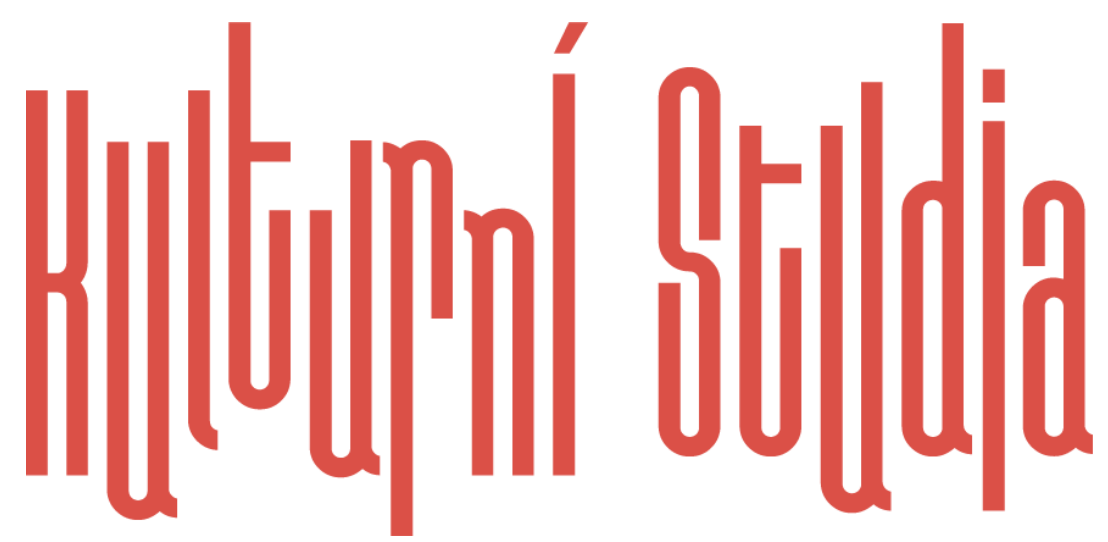

Šestnácté číslo časopisu Kulturní studia, vychází 1. května 2021

Vydává z. s. Kulturní studia, při oboru Hospodářská a kulturní studia, PEF ČZU 




\title{
Evropský národ vs. globalizovaný nacionalismus
}

\author{
European nation vs. globalized nationalism \\ Miroslav Hroch \\ Institut politologických studií Fakulty humanitních studií Univerzity Karlovy v Praze \\ Pekařská 16, 15800 Praha 5 \\ Email: hrochmir@seznam.cz
}

DOI: https://dx.doi.org/10.7160/KS.2021.150101

Prof. PhDr. Miroslav Hroch, DrSc., dr. h. c. je český historik a pedagog působící na Karlově univerzitě v Praze, nejprve na Filosofické fakultě, od roku 2000 na Fakultě humanitních studií. Zabývá se dějinami novověku, zejména srovnávacími dějinami národních hnutí v Evropě.

\begin{abstract}
The author recommends that any consideration of the issue of nation and nationalism should be preceded by a careful analysis of the terminology used. He points out that the key term 'nation' itself should be used in the knowledge that it refers, on the one hand, to a specific large group of citizens - members of a nation, but also to an abstract value community of culture. He critically rejects the thoughtless use of the term 'nationalism', which forgets that it is derived from the term 'nation'. This is a dangerous distortion, especially when applied to non-European realities. A nation is originally a specifically European phenomenon, that is to say, a community that grows out of the old cultural and ideological resources of European countries. If the globalised term nationalism is used retrospectively to analyse the history or present of European nations, there is a danger of distortion and misunderstanding. Just as distorting, however, can be the analysis of non-European 'nations' in the coordinates of the European nation. In conclusion, the author points out that the humanistic and motivational values of the European nation from the time of its formation are largely an empty phrase for contemporary nations. The reason for this, however, lies not only in terminological confusion, but also in the great transformation of value norms as a result of the neoliberal questioning of national values and identities that is being promoted in the context of advancing globalisation.
\end{abstract}

\section{Keywords}

nation, national movement, nationalism, globalised nationalism

\section{Klíčová slova}

národ, národní hnutí, nacionalismus, globalizovaný nacionalismus 


\section{Úvod}

Termín nacionalismus patří k těm, které dnes žijí svým vlastním životem bez ohledu na to, jakou vlastně realitu označují (nebo mají označovat), podobně je na tom třeba komunismus, humanita, lidská práva. Navíc se dnes s ním setkáváme jako s globálním fenoménem - jako termín se objevuje všude na světě. Při tom jde o termín mírně řečeno mlhavý, mnohoznačný, většinou užívaný jako diskvalifikující nálepka či dokonce nadávka, někdy jako neutrální nástroj analýzy, ale v některých jazycích (španělština) původně jako pozitivní hodnota. Jak v určení obsahu, tak i v hodnotící perspektivě pozorujeme tedy diametrální rozdíly. V tomto př́spěvku bych rád upozornil na několik souvislostí, které je třeba brát v úvahu, chceme-li zmatkům kolem nacionalismu porozumět a kriticky je posoudit.

Především bych rád připomněl skutečnost, že termín nacionalismus je odvozen od termínu (a reality) národ a měl by být uživán právě jen v kontextu s národem. Proto bude třeba předložit základní údaje o tom, jak se chápal a chápe fenomén národ, při čemž hned úvodem nutno upozornit, že národ je v původním smyslu specificky evropský fenomén, a to nejen $\mathrm{v}$ rovině pojmoslovné. A to zase nelze vysvětlit bez výkladu o tom, jak se moderní (evropský) národ formoval. V té souvislosti hodlám upozornit na zanedbávanou okolnost, že termínem národ neoznačujeme jen konkrétní soubor lidí v našem okolí, ale že jde zároveň o abstraktum označující konstrukci - hodnotovou kulturní pospolitost.

\section{Dvojí poloha národní existence}

Není samoúčelem princip, že na začátku každé analýzy nutno začít termíny, které mají být jejím nástrojem. Zde tedy termínem „národ“, který tvoří základ všeho - a především je to historicky mnohem starší termín. I když dnes při označování všeho, co souvisí s národem, dominuje termín nacionalismus, je to pouze novotvar odvozený ve většině evropských jazyků od latinského „natio“, „natus sum“ Čeština jako jeden z mála jazyků si termín přeložila. Nechám stranou více než století trvající diskuze o definici národa. Pro hrubou orientaci jen uvedu, že v těchto diskuzích se chápání národa a jeho zrodu pohybovalo mezi dvěma krajními polohami. Na jedné straně to je představa, že národ je určován objektivními, tj. na vůli jedince nezávislými faktory a okolnostmi, na druhé straně názor, že národ je určen především, ba výlučně tím, že se určitá množina lidí za národ považuje. Zjednodušeně pak se v různých přehledech užívá označení, jako je třeba na jedné straně „konstruktivismus“ a na druhé „primordialismus“ (resp. „esencialismus“). Nemusí to však být protiklady neslučitelné. 
Neexistuje konsenzuální definice národa, a proto je vhodné, aby každý autor, který tohoto termínu užívá, hned na začátku sdělil, co pod tímto pojmem chápe. Což zde musím učinit i já, ve snaze být srozumitelný.

Vycházím z toho, že každý z nás si spontánně, bez reflexe, vybavuje termín národ ve dvojí poloze, ve dvojím kontextu, a užívá ho podle okolností, živelně v jedné či druhé z těchto poloh, což často vede k nedorozuměním. Běžnější polohou je národ jako každému srozumitelné označení konkrétní, objektivně existující množiny lidí, velké sociální skupiny, jejíž př́íslušníci si uvědomují, že patří k této skupině a přijímají tuto příslušnost jako pozitivní složku svého života. Komunikují spolu v koloběhu každodenního života, dostávají se do konfliktů, nebo se naopak sdružují za dílčím zájmem - v tom je jim národ rámcem, kterého v případě potřeby využívají. Vazby, vztahy mezi příslušníky této skupiny mají velmi často (ale ne vždy) své kořeny hluboko v minulosti, ve středověku, ale konstituovaly se teprve v průběhu modernizace - tj. zhruba v průběhu 19. století. Nelze určit stabilní, všeobecně platnou kombinaci těchto vztahů (teritoriálních, jazykových, kulturních, politických hospodářských, náboženských aj.), každý mohl být modifikován, mohl i absentovat a být substituován vztahem jiným. Vždy však bylo nenahraditelnou charakteristikou národní existence trojí:

- jeho př́slušníci si jsou vědomi toho, že patří k sobě a že jsou spojeni společnou minulostí,

- za druhé, komunikují spolu navzájem intenzivněji, než s okolními skupinami (odtud mimořádný význam jazyka),

- za třetí, tvoří pospolitost občanů, kteří jsou si rovní, i když jsou sociálně a profesně stratifikováni.

Je zde však také druhá poloha, kterou si ne vždy zřetelně uvědomujeme. Je to termín „národ“ jako označení abstraktní kulturní pospolitosti, jako idea či přesněji možná konstrukce, která se zrodila $v$ hlavách vzdělanců (či politiků) a má pro ně pozitivní hodnotovou konotaci. Zde se uvažuje o národu jako celku, bez ohledu na sociální stratifikaci. Pokud se berou $\mathrm{v}$ úvahu zájmově rozdíly dílčích složek národa, pak s ohledem na harmonizující funkci národa - jeho elementární hodnotou je sama takováto jeho existence. Idea národa jako abstraktní hodnoty se rodila $\mathrm{v}$ období utváření novodobého národa, ale měla u mnohých evropských národů mnohem starší kořeny.

Masové prrijetí identity spojené s národem v poloze sociální skupiny ovšem nemusilo automaticky znamenat také uvědomělé přijetí této ideje národa jako abstraktní hodnotové 
pospolitosti každým z příslušníků této skupiny. Naopak, v procesu formování národa, resp. národního hnutí národní předáci chápali „národ“ jako hotový uzavřený konstrukt a hodnotu, přičemž pro ně nebylo důležité, zda jeho potenciální př́slušníci již s nimi sdílejí národní identitu či nikoli.

Obojí rovina - konkrétně sociální a abstraktně kulturní - se ovšem prolíná. Součástí nové národní identity se v období formování moderních národů stala představa o národu jako hodnotové abstraktní pospolitosti a naopak ,idea národa“ byla v myslích jeho prríslušníků modifikována podle toho, jaké měli vzdělání a jaké místo zaujímali v sociální struktuře národní společnosti.

\section{Potíž s termíny: od národa k nacionalismu}

At’ už diferencovaně či nikoli, dnes je termín „národ“ - nation celosvětovým fenoménem společností národů počínaje a desítkami indiánských národů v Latinské i Severní Americe a kmenových či jiných pospolitostí v Africe konče.

Proč takový úspěch? Neodvažuji si odpovědět komplexně, upozorním jen na některé nesporné souvislosti. Být národem dnes téměř vždy a všude na světě je cosi prestižního a hlavně to implikuje určitá práva a tato práva se zakládají jednak na respektu ke kulturní specifice, ale také, ba především, to zahrnuje jisté politické, resp. mocenské ambice: „konečně si vládneme sami“. To sice zní jednoznačně, ale ponechme zatím stranou výhrady, jako otázku „kdo si to vlastně vládne a komu?“. Očima těch, kdo světu vládnou i očima politologů a sociologů je současný globalizující se svět světem nejrůzněji definovatelných pospolitostí, které označují jako národy. Vzhledem k tomu, že angličtina je lingua franca globální politiky i vědy, míní se těmi pospolitostmi „nations“v onom smyslu, jak tento termín chápe již od 17. století angličtina tedy ve smyslu svébytných politických celků - států. United Nations sice překládáme do češtiny jako národy, ale dobře víme, že to nejsou národy v onom smyslu, jak jim rozumí evropská kulturní tradice.

Svět žurnalistiky a bohužel také svět soudobé vědy - at' již politologie či sociologie s tímto terminologickým zauzlením nemá problém, protože tu pestrou směs různorodých politických celků zastřešuje jiným, mnohem frekventovanějším termínem - „nationalism“, který jako produkt terminologické globalizace se bezmyšlenkovitě aplikuje na světové, evropské či české procesy, a to nejen současné, ale i minulé. Pod takový terminologický deštník se vejde Dalimil, Luther, Masaryk i Mussolini. Z toho důvodu dávám přednost anglickému „nationalism“, když hovořím o tom, co se děje mimo Evropu a v současnosti, 
abych naznačil, že jde o procesy odlišné od toho, co označujeme českým ekvivalentem tohoto termínu při analýze evropských záležitostí - at' již v současnosti nebo v minulosti.

Pokoušíme-li se definovat „,nationalism“, platí zde v ještě větší míře než v případě termínu „nation“, že neexistuje konsenzuální definice. Dokonce dnes neplatí ona vágní představa, která platila ještě před několika desetiletími, že totiž „,nationalism“ označuje vše, co se nějak vztahuje k národu, resp. „nation“. Dnes už vanglosaských textech najdeme termíny jako „white nationalism“ „Trumpian nationalism“, „Hong-kong nationalism“ „Latin American nationalism“ „white nationalism“ atd. Tak se ad absurdum dovedla kdysi jako bonmot míněná věta Ernesta Gellnera, že to je nacionalismus, co utváří národy. Národ je nakonec prezentován jako virtuální realita, která existuje pro nás jen díky tomu, že jsme schopni pro nějaký proces, jev, sociální segment aplikovat označení „,nationalism“ ve smyslu pocitu pospolitosti, společného zájmu, resp. pouhé verbální oddanosti, přináležitosti. Činí se tak bez ohledu na to, jaká realita se tím označuje.

Př́íslušníci nultietnických státních celků, jako Indonésie a Indie, nemluvě již o většině afrických států, jsou „nations“, protože u jejich politických a někdy i akademických elit lze vystopovat pocit identifikace s takto nazvaným celkem - a tedy „nationalism“. Při tom je obtížné jednoznačně určit, ke které ze dvou poloh národa, jak jsem je charakterizoval v úvodu, se termín váže. Odvažuji se zde formulovat jen jako hypotézu, že to je primérně poloha sociální reality - tedy jako postoje konkrétních „nacionalistů“. Teprve odvozeně se hledají hodnoty, k nimž by se „nationalism“ hlásil, resp. jimiž by argumentoval ve snaze posílit soudržnost celku zvaného ,nation“.

Zatímco žurnalistům (a ostatně ani většině politiků) tato terminologická zamlženost nevadí, mnozí politologové a další sociální vědci si uvědomují, že mnohoznačnost termínu „nationalism“ snižuje jeho vypovídací schopnost až k nule. Proto se už před polovinou 20. století objevily (a pak stále častěji se objevují) pokusy specifikovat rozdíly pomocí adjektiv státní, imperiální, ale také humanistický, liberální, integrální a podobně. Zvlášt' citlivý je Evropan citlivý na užívání termínu „nationalism“ jako označení identity s národem, který je definován mimo jiné společným vlastním jazykem, jak to je běžné u většiny národů evropských, ale jen zřídka na ostatních kontinentech. Ve snaze o specifikaci užívají někteří autoři termínu „ethnonationalism“, obvykle ovšem s pejorativním odstínem. Nebot' v soudobém evropském mainstreamu, který už národ nepovažuje za evropskou hodnotu, se „ethnos“ označuje za protiklad občanského principu, a tedy jako označení něčeho, co se pro 
správného Evropana nesluší. Tuto představu považuji nejen za mylnou, ale dokonce za nebezpečnou.

Tím se dostávám k dalšímu chronickému sporu kolem nacionalismu. Je to spor o jeho hodnocení. Jestliže nějaký postoj označíme za nacionalistický, nějakého politika za nacionalistu, míníme to obvykle jako kritiku. V české jazykové tradici tomu tak je od samého počátku, protože tento termín většinou užíváme pro označení jevů a postojů, které hodnotíme záporně. V německé jazykové tradici tomu bylo obdobně, ovšem jen zhruba do poloviny minulého století. Pak se objevuje snaha o neutralizaci pojmu tak, jak se o to snažil už ve třicátých letech americký historik Carlton J. Hayes. Adjektivem měl pak být diferencován pozitivní či negativní odstín. Ve střední Evropě se jako prvý pokusil tuto neutralizaci aplikovat německý historik, rodák z Liberce, Eugen Lemberg. Nepodařilo se mu však tuto koncepci prosadit. Dodnes se někteří němečtí autoři kloní ke spíše negativní konotaci, ale častější jsou autoři, kteří označují nacionalismus za hodnotově ambivalentní: podle situace někdy pozitivní, jindy negativní. Navzdory tomuto deklarovanému pohledu však považují nacionalismus za něco nepatřičného.

Angličtí a zejména američtí autoři sice často zdůrazňují, že to je pro ně terminus technicus, ale podíváme-li se blíže, máme dojem jistého pokrytectví. Zejména o amerických autorech platí, že většinou neužijí tohoto termínu když jde o USA. Je to pro ně termín negativní, který rádi a běžně uživají, když píšou o neamerické realitě, tedy o jiných národech, nebo kritizují nějaké stránky amerického života. Pro označení pozitivního vztahu k národu však užívají téměř výlučně „American patriotism“. Mnozí anglosaští autoři však si jsou vědomi nízké výpovědní hodnoty termínu „nationalism“ a hledají nějaké další termíny, především právě „,patriotism“. Významný antropolog Cliffort Geerts hovoří o „,bezvýhradné loajalitě“. Je příznačné, že Lemberg definuje nacionalismus jako hodnotově neutrální tak, že jej nevztahuje k národu ve vlastním slova smyslu. Definuje jej totiž jako „bezvýhradnou oddanost nadosobnímu celku“.

V evropském i americkém mainstreamu dominuje „nationalism“ jako označení všech postojů a aktivit, které se odvolávají na entitu, kterou nazývají v podstatě voluntaristicky národem (nation). Jde tedy o převážně kritické nebo alespoň distancující se označení postoje, který vyrůstá ze vztahu ke skupině, pospolitosti, která je podle názoru těchto kritiků vlastně uměle vytvořená či v horším prŕípadě dokonce manipulativně konstruovaná „,nacionalisty“, kteří usilují dostat se k moci či dosáhnout jiných egoistických cílů. Takováto představa možná platí pro utváření „nations“ na území mimoevropských kontinentů, zejména někdejších 
kolonií, ale je v př́padě evropských národů v rozporu s empirickými daty, která známe nejen o Evropě jako celku, ale i o jednotlivých národech. Především zdůrazňuji, že termínu „nationalism“ nelze užívat při analýze procesu utváření národů a jeho historických kořenů v Evropě, že jej tedy nelze transponovat do dějin kontinentu, který je kolébkou moderního národa.

Dříve, než přistoupím $\mathrm{k}$ další složce našeho tématu - $\mathrm{k}$ historické analýze formování národů - bude třeba shrnout úvahy o terminologii spjatou s národní existencí a Evropou. Tato analýza pracuje se třemi termíny, které se zrodily v Evropě jako označení na tomto kontinentě začínajících procesů a postojů - národ, patriotismus, nacionalismus. následně byly aplikovány také na obdobné (ale nikoli totožné) mimoevropské procesy a vrátily se jaksi nepozorovaně zpět do Evropy jako nástroj vědecké analýzy oněch procesů, z nichž původně byly odvozeny. Ale tyto termíny - poté, co prošly globalizací různého druhu - již neoznačují to, co znamenaly původně.

Při tom nejde jen o kritiku užívání samotného termínu „nationalism“ - tomu užívání se nakonec můžeme vyhnout - ale především o to, zamyslet se nad Evropou, nad jejím místem ve světě, přičemž takové zamyšlení nemůže být zakotveno jinak než historicky.

\section{Národ se v Evropě utvářel jako kulturní hodnota}

Jednou ze základních skutečností, kterou chci v této stati zdůraznit a zdůvodnit, je evropské zakotvení národa. Moderní národ a identita s tímto národem - vznikal a utvářel se v podmínkách evropské modernizace na základě specificky evropských historických, resp. kulturních tradic. Jde tedy o termín označující specificky evropský útvar a tomu odpovídající termín, který byl postupně exportován mimo Evropu do zemí se zcela odlišnou kulturní a náboženskou tradicí i odlišnou sociálně-ekonomickou strukturou.

Pokusím-li se tedy o historický výklad této skutečnosti, musím brát v úvahu vzájemné propojení proměňující se společenské reality na jedné straně a termínů, jichž doba užívala pro tyto transformace na straně druhé. Touto realitou míníme Evropu devatenáctého století, kdy pospolitost označovaná termínem národ byla považována za přirozenou pospolitostí a za hodnotu a kdy vztah k ní, v češtině označovaný jako vlastenectví, byl chápán jako závazek. Nacionalismus byl označením jistého typu postoje k národu a - jak již bylo řečeno - objevil se jako termín se teprve na přelomu 19. a 20. století, tedy v době, kdy většina evropských národů byla již plně formována. Jednalo se tedy na rozdíl od termínu „,národ“, „natio“ jenž má 
své kořeny již ve středověku, o odvozený novotvar. Jak již jsem naznačil, současný výčet evropských hodnot nezmiňuje národ ani vlastenectví.

Stojíme tedy před otázkou, jak to začalo? Odkud vyrůstaly základy? Nicméně základy čeho? - národa jako „ideje“ nebo jako sociální skupiny? Zde bude třeba se vrátit k rozlišení dvou rovin existence národa, které jsem charakterizoval v úvodní části. Uvedl jsem již, že se obvykle nerozlišuje, zda je míněn národ jako abstraktní koncept, idea nebo národ jako konkrétní sociální útvar. Spíše byl rozdíl v akcentech: někdo více zdůrazňoval ideu a zahrnoval pod ní automaticky i pospolitost, jiní - k nim patřím také já - spíše analyzovali sociální skupinu, která - pokud přijala ideu národní pospolitosti - byla rozhodující vlastně také pro úspěšné formování moderního národa.

Hledání počátků začnu abstraktním konceptem národa, jeho ideou, nebot' s ní byl neodlučně spjat i termín sám. Obecně řečeno, středověký latinský termín „natio“ dostal nové významy utvářejících se v národních jazycích (nation, národ atd.), a s tím se transformoval postupně jeho obsah. Původně označoval jistou skupinu, vrstvu lidí, rozhodně nikoli všechnu pospolitost na jistém území. Známý je příklad univerzitních „nationes“, což bylo označení pro studenty přicházející z jistého regionu či státu, jistou obdobu najdeme i na církevních koncilech. Sociálně exkluzivní bylo uherské „Natio Hungarica“, zahrnující pouze uherskou šlechtu, obdobně jako „Natio Polonica“ zahrnovalo šlechtu polské Rzeczy Pospolité. Stejně sociálně výlučné bylo 16. století německé „Deutsche Nation“. Naproti tomu zahrnovalo v 16. století anglické „nation“ také města - samozrrejmě spolu se šlechtou. U Komenského patřila k národu (v latině „gens“) celá pospolitost lidí hovořících jedním jazykem a žijící na jednom území. Jeho definici bychom mohli považovat za paralelu k tehdejšímu chápání národa $\mathrm{v}$ Anglii.

Nutno dodat, že v humanismu a později také v osvícenství byl konotován termín národ ve všech jazykových variantách převážně pozitivně či alespoň neutrálně. Snad díky tomu nebylo obtížné dát tomuto termínu a konceptu během poslední třetiny osmnáctého století, resp. na prahu století devatenáctého nový obsah: národ začal být považován za hodnotu sám o sobě, za př́nos ke kulturní mnohotvárnosti lidstva. Národ dostává novou hodnotu jako přirozený samozřejmý domov všech svých příslušníků - občanů, stává se útočištěm ale také, třeba u francouzských jakobínů, závazkem solidarity a prospěšnosti jedince vůči celku. To vše ovšem v poloze ideálu, podobně jako představa o propojení s představou civilizačního, resp. kultivujícího poslání národa. Jakkoli to zní paradoxně, v pohledu na národ - stále hovořím o 
abstraktní hodnotové poloze - zde byla zřejmá konvergence herderovské a revoluční „jakobínské“" a pozdější romantické koncepce národa, jakkoli bývaly dávány do protikladu.

Pozitivní konotace termínu národ nespadla z nebe: můžeme hledat kořeny pradávné, k nimž patři na prvém místě starozákonní představa o „vyvoleném národu“ vůči němuž mají všichni jeho př́ślušníci závazek. Musíme připomenout, že zřejmě odtud vyrůstal reformační ethos rovných si členů obce. Sekulární kořeny měl zřejmě osvícenský regionální patriotismus, jenž zavazoval vzdělaného jedince k zodpovědnosti za životní styl prostých obyvatel jeho země, jeho regionu. Obvykle byla s národem jako ideou spojena i představa o národu jako odvěké pospolitosti. Takový „národ o sobě“ nepočítá s tím, kolik lidí se k němu uvědoměle hlásí, rozhodující je, že žije jako idea, jako „národ v srdcích“.

Osvícenství učinilo z termínu národ jeden z běžných nástrojů rozboru společenských a politických problémů. Známe úvahy o národní hrdosti, o národní povaze, známe chvály národních jazyků. Přijetí termínu národ $\mathrm{s}$ pozitivní konotací šlo jaksi ruku $\mathrm{v}$ ruce $\mathrm{s}$ osvíceneckým regionálním patriotismem vzdělanců (nezaměňovat se zemským patriotismem šlechticů, jimž šlo o zachování šlechtických privilegií). Tento patriotismus byl etickým požadavkem, jenž zavazoval vzdělance k činorodé práci ve prospěch vlasti pro povznesení jejích obyvatel. S osvíceneckým patriotismem byla spojena představa, že stát (jeho panovník, jeho elity) jako světská instituce má zajistit každému jedinci základní vzdělání a občanskou výchovu. V Nizozemí označoval termín patrioti ve druhé polovině 18. století účastníky politického, občanského hnutí. At’ již se $\mathrm{v}$ oné době termín národ vyskytl $\mathrm{v}$ jakémkoli kontextu, byl označením jakési hodnoty, termínem, který v sobě nesl pozitivní náboj.

V kontrastu vůči světskému patriotismu vystoupil ve stejné době J. G. Herder, pro kterého byl národ (definovaný společným jazykem a kulturou) stvořen Bohem a povolán k tomu, aby se stal základním nástrojem humanity, ukazatelem a průkopníkem cesty k zušlecht'ování lidstva. Pravděpodobně u Herdera můžeme pozorovat kořeny jakéhosi „dualismu“ v chápání národa: spočívá v tom, že na jedné straně si představuje národ jako dílo boží, jako abstrakci, která je mravní a kulturní hodnotou o sobě (ta je u Herdera dominantní), na druhé straně stojí představa národa (pro Herdera jaksi doprovodná) jako velké skupiny, pospolitosti konkrétních jedinců, které je třeba přesvědčit o tom, že od věků náležejí k oné hodnotové abstrakci.

To vše se datuje do několika desetiletí před Francouzskou revolucí, s níž běžný povrchní stereotyp spojuje počátek glorifikace národa jako abstraktní konstrukce, která se odtud po revoluci měla šířit Evropou. Ve skutečnosti revoluční Francie jen 
institucionalizovala a glorifikovala abstraktní ideál národa, který se rodil z osvíceneckého patriotismu, resp. herderovského preromantismu předchozích dob. Skutečnou revoluční inovaci tohoto termínu vidím jinde - v tom, že mu revoluce dala nový sociální obsah: deklarovala jej jako pospolitost rovnoprávných a solidárně jednajících občanů bez ohledu na majetek a vzdělanost. Všichni občané (nejen osvícení vzdělanci) byli zavázáni k práci pro vlast, což znamenalo práci pro pokrok a svobodu. To byl zajisté základ pro aplikaci principu občanství. Zároveň si však občané, př́ślušníci národa, měli osvojit spisovnou formu své mateřštiny a získat tak prŕstup $\mathrm{k}$ historicky vzniklým, mnohdy zapomenutým hodnotám národní kultury. Tuto dlouhou předehru, historické zakotvení, které zakládalo mýtus národa jako pozitivní hodnoty, najdeme pouze v Evropě.

\section{Národ jako sociální realita a občanská společnost}

Teprve když si uvědomíme tuto intelektuální předehru, můžeme porozumět procesu utváření národa $\mathrm{v}$ oné druhé rovině - národa jako konkrétní pospolitosti, resp. sociální skupiny. Tento národ jako pospolitost rovných občanů sdílející nejen vědomí sounáležitosti jako hodnoty, ale také vzájemně komunikující, s jistým stupněm organizovanosti se rodil z krize identit, kterou přinášel postupný rozklad starých hodnot a vazeb feudální společnosti.

Není rozhodující, zda označíme systém, který byl v krizi, za systém feudální či předmoderní. Právě tak není důležité, zda systém, který na místo starého nastupoval, opatříme adjektivem moderní, kapitalistický, industriální. Krize a z ní plynoucí proměny probíhaly v některých zemích a v některých sférách života pozvolna, jinde naopak prudce a revolučně. Není zde dostatek místa na charakteristiku této krizové situace, která otřásla sférou poddanských vztahů, zpochybňovala autoritu církve i vrchností, nastolovala, byt' zatím jen formální, rovnost lidí před zákonem atd. Pro lepší porozumění uvádím ve stručném shrnutí nejdůležitější př́klady těchto proměn.

1) Tradiční sociální vazby a závislosti, založené na privilegiích a feudální pozemkové držbě, at' již měly povahu nevolnictví či poddanství, začaly být zpochybňovány a odstraňovány.

2) Uzavřený svět patrimoniálního či seigneuriálního systému se uvolňoval, stával se méně restriktivním, stavovské bariéry se zdály být prostupnější pro tok informací i pro pohyb lidí ve stále výrazněji se prosazujícím a modernizujícím státě. 
3) Stále větší část (byt' nadále menšina) lidí mohla př̌kročit hranice stanovené panstvím, doménou, někdy bylo možné i trvale opustit omezený svět, v němž žily generace jejich předků: dílem na cestě za obživou, dílem ve snaze získat vyšší vzdělání.

4) Cechovně reglementované řemeslné výrobě ve městech začala konkurovat velkovýroba, nejprve $\mathrm{v}$ podobě manufaktur, později $\mathrm{v}$ podobě továren, a nutila masu řemeslníků hledat nové cesty a nová řešení.

5) Postupně se prosazovala náboženská tolerance a sekularizace, a s tím ustupovala církevní kontrola intelektuálního a kulturního dění: pro rostoucí část obyvatel přestávalo být náboženství základním pilířem jejich identifikace.

6) Náboženská legitimizace nerovnosti lidí a privilegovaných autorit z období feudalismu byla stále častěji zpochybňována a s ní byl zpochybňován i tradiční systém hodnot.

7) Pozvolna se prosazovala - nejprve mezi vzdělanci - myšlenka, že lidé jsou si rovni před zákonem, a tedy také před státními institucemi, a odtud se rodila představa, že všichni jedinci mají stejnou hodnotu bez ohledu na to, zda mají šlechtický, měštanský či poddanský původ.

Všechny tyto (a mnohé další) proměny probíhaly na evropském území nerovnoměrně, tedy $\mathrm{v}$ různém čase, $\mathrm{v}$ různé kombinaci a s různým trváním. Všude však podnítily, nejprve především v řadách vzdělanců, znejistění a krizi identit, utváření nových vazeb, hledání nové pospolitosti. Právě teprve na jisté vzdělanostní úrovni se vytvářel další předpoklad formování nové pospolitosti - schopnost imaginace - schopnost představit si, že k té pospolitosti, k níž se hlásím, s níž bych se měl ztotožnit, patř́i lidé, které neznám a nikdy nepotkám, a kteří žijí na teritoriu, které nikdy neprocestuji, a které se přesto označuje jako moje vlast.

Vznikání nových vazeb, komunikačních propojení, nový typ skupiny - při tom není centrálně důležité, jak ji nazvat - nicméně termín vhodný pro označení nové entity už tu byl „prefabrikován“ z minulosti a aplikován v podmínkách některých států v Evropě. Byl to termín národ. Nebylo při tom důležité, zda státně organizovány, či nikoli - rozhodující bylo určení společným jazykem, minulosti, kulturou. Tak se v Evropě zrodily s nástupem občanské společnosti nové velké pospolitosti, - a ty dostaly označení starým termínem národ, který původně neoznačoval společnost občanskou.

Takovéto utváření národa probíhalo v Evropě, zjednodušeně řečeno, dvojí cestou a jeho výsledkem byly dodnes existující dva typy národa (s několika přechodnými prŕpady). Rozlišuji tyto dva typy podle toho, z jaké výchozí situace formování národa probíhalo. 
Výchozí situací prvého typy byl stát, který měl svoji kontinuitu od středověku, vyspělou „národní“ kulturu ve vlastním jazyce, a elity, konkrétně řečeno, působila tam se šlechta a měšt’anstvo, které tuto kulturu sdílely a rozvíjely. Na půdě tohoto státu probíhala od jisté krizové doby vnitřní (tj. vnitrostátní) transformace stavovské společnosti nerovných ve společnost občanskou, která se deklaruje jako národ rovných občanů - tento stát-národ zajišt'uje občanovi ochranu, a prŕpadně také prestiž navenek, avšak zároveň požaduje od svého př́slušníka solidaritu s „,národem“ jako abstraktní pospolitostí. K tomuto typu formování národa patřila Francie, Nizozemí, Portugalsko, Dánsko Švédsko, Anglie, Španělsko, tedy menšina ze soudobých evropských národů. Pro lepší porozumění pro ně volím název „státní národy“.

Výchozí situace druhého typu byla složitější. Byla to situace etnické pospolitosti, která žila na území multietnické říše. Byla to tedy situace pospolitosti s neplnou sociální strukturou, tedy bez ekonomických a akademických elit, bez vlastního státu a s porušenou nebo absentující kontinuitou kultury a literárního jazyka. Cestou $\mathrm{k}$ formování národa byla cílevědomá snaha předáků této skupiny, vlastenců, získat všechny atributy plnohodnotné národní existence, kterou označujeme jako národní hnutí, kdy se teprve př́slušníci etnické skupiny, nejprve ti, kdo získali vyšší vzdělání, rozhodují pro příslušnost k národu. Také zde byl prvým stimulem výše popsaný prožitek krize staré společnosti, krize starých legitimit, starých hodnotových systémů. Svůj význam měly na jedné straně myšlenky rovnosti lidí, na druhé straně také tržní vazby, stejně jako sociální emancipace, jejíž nejdůležitější složkou bylo obvykle tzv. osvobozování rolníků. Po sociální emancipaci nebo zároveň s ní probíhala také emancipace politická, otevírající cestu k politické participaci.

Národní hnutí probíhala v Evropě asynchronně a také skladba jejich programu, jejich cílů se lišila. Vždy však v tomto programu byly zastoupeny - byt' s rozdílnými akcenty a rozlišnou datací - požadavky kulturně-jazykové, sociálně emancipační a politické. Také jejich průběh se odvíjel podle stejné trajektorie. Na prahu stálo období, které označuji jako fázi A, která se vyznačovala převážně učeneckým zájmem o jazyk, kulturu, minulost, zvyklosti etnické skupiny, která je stále častěji, byt' ne vždy označována termínem národ. Na půdě tohoto vzdělaneckého zájmu dozrála dříve či později myšlenka, že příslušníci etnické pospolitosti - národa by si svoji př́islušnost k národu měli uvědomit jako cosi hodnotného, jako hodnotový celek, pro který je třeba se angažovat. Tak začala agitační fáze B, která většinou, ale nikoli vždy dosáhla úspěchu v podobě získání podpory v širokých vrstvách obyvatelstva, takže národní hnutí vstoupilo do své masové fáze, kterou označuji jako fázi C. 
Obvykle se teprve v průběhu této fáze s národem začaly identifikovat nejen akademické, ale také střední vrstvy a podnikatelské elity, resp. jejich část, takže můžeme hovořit o plně zformovaném národě, a to bez ohledu na to, zda dosáhl státnosti či nikoli.

At’ už se to někomu líbí či nikoli, naprostá většina evropských národních hnutí byla úspěšná a vyústila v ustavení národního státu. Byl to však stát jiného typu ne onen, jenž se zrodil modernizací státního národa. Jeho obyvatelé sdíleli odlišné stereotypy a odlišný hodnotový pohled na svět. Proto je označuji za „malé národy“, při čemž však adjektivum „malý“ není charakteristikou kvantitativní (počet obyvatel), ale typologickou. Proto neřadím k malým národům Dány, ale naopak k nim řadím šestinásobně početné Ukrajince. K charakteristice malého národa např́klad patří stereotypní představa nesamozřejmosti národní existence, pocit vnějšího ohrožení, snaha prokázat právo na obecné uznání, pochyby o tom, zda svébytná existence jako národa má smysl. Jsou zde však také objektivní okolnosti, z nichž uvádím alespoň jednu: Malé národy se nepodílely na evropské koloniální expanzi a jejich př́slušníci proto mají odlišný vztah k rasovým problémům, stejně jako k obyvatelům jiných kontinentů, což se zřetelně projevilo v imigrantské krizi.

Dvě cesty formování národa se odrazily také v dualismu sémantickém: je to rozdíl mezi výše zmíněným anglickým a středoevropským (zjednodušeně řečeno) pojetím spočívající v tom, že anglické „nation“ je velmi blízké státu, v podstatě implikuje existenci národního státu, či alespoň nárok na vlastní národní stát. Naproti tomu v české i německé terminologii je národ definován společnou kulturou, jazykem a př́ípadně i historií. Národ v naší jazykové tradici tedy označuje pospolitost, která může existovat bez státu.

Pro přesnost nutno dodat, že mezi právě zmíněnými dvěma základními typy formování evropského národa známe ještě typ třetí, jaksi přechodný, k němuž patří Němci, Italové a Poláci. V těchto třech případech stála $\mathrm{v} 19$. století na počátku formování národa společenství s plnou sociální strukturou, s vyspělou kulturou v národním jazyce, ale bez vlastního národního státu. Také zde se tedy hovoří o národním hnutí, ale jeho základním cílem bylo vytvořit jednotný stát. Proto se tato hnutí často označují jako sjednocovací.

Pro označení vztahu jedince k národu pak se v období formativním obvykle užívalo termínu patriotismus - s ekvivalenty v jednotlivých jazycích (v češtině vlastenectví). Teprve později, na prahu 20. století, se pro ztotožnění jedince s národem začalo, jak víme, stále častěji uživat označení mnohoznačným termínem nacionalismus. 


\section{Národ a nacionalismus ve víru globalizace}

Termíny národ a nacionalismus, které se historicky zrodily na evropské půdě, se pak během 20. století, poté, co zformovaly moderní národy, staly exportním zbožím. Nebudu sledovat, jak se to stalo, ale důležitý je výsledek: všudypřítomný termín „nation“ jako státně-národní celek byl zastíněn stále frekventovanějším (a ještě mlhavějším) „nationalism“. Ten export ovšem nesměřoval zdaleka do prostředí, které bylo všude stejné či obdobné. Naopak, mezi kontinenty i uvnitř kontinentů šlo o teritoria na rozdílném stupni vývoje a s rozdílnou kulturní tradicí, při čemž ty obrovské rozdíly, měly být právě tímto importem termínu „nation“a a hlavně termín „nationalism“ jaksi překryty. Bylo to př̌krytí úspěšné, což nic nemění na skutečnosti, že neodpovídalo realitě. Tím chci říci, že celky, které se na různých místech světa označují jako „nation“, zdaleka nelze považovat za shodné s těmi, které se v Evropě většinou již od 19. století zformovaly jako moderní národy. Někdy mají společné právě jen to označení - a samozřejmě nárok na to, aby se s ním všichni obyvatelé státu ztotožnili.

Proto bude možná užitečné ve stručnosti připomenout, o jaké typy společností se před nástupem této z Evropy importované „nacionalizace“ jednalo. Byly to, za prvé, velké státní útvary, centralizované monarchie s jednou odedávna dominující kulturou a jazykem, byt' s etnickými menšinami, jako byla Čína, Japonsko, Persie či Osmanská říše. V těchto př́padech známe jisté paralely k evropské cestě státních národů. Dále to byla ona část kolonií, které byly nuceny zčásti nebo zcela převzít jazyk a kulturu své koloniální mocnosti, ale jejichž elity úspěšně usilovaly emancipovat se politicky od „mateřské země“. Sem paří na jedné straně státy Latinské Ameriky, na druhé straně multietnická Indie. Některé kolonie, jako Indonésie či Vietnam, si však udržely svoji kulturní a jazykovou svébytnost. Ve většině Afriky se nezávislými státy (označující se jako nations) stávaly osvobozující se kolonie, jejichž území bylo natolik etnicky heterogenní, že jejich emancipující se vzdělané elity si zachovaly jazyk koloniální mocnosti, ale uvnitř těchto osvobodivších se kolonií někdy vznikla hnutí, která argumentují etnickou svébytností a vlastním jazykem. Tato hnutí, která známe i z Asie, jsou typologicky nejblíže k hnutím evropským (např. Tamilové, Ibové, Tchajvanci, Kurdové). Nakonec je třeba zmínit mimoevropské národy, jejichž národní identita a př́padně i kultura se utvářela jako výsledek národnostní politiky v předstalinském období multietnického SSSR, ale které se po jeho rozpadu osamostatnily a budují státně-národní identitu spojenou s kulturní svébytností. Myšlenka etnicky definovaného národa zde prrišla „shora“, ale ujala se. 
Při všech rozdílech je společnou charakteristikou, která platí pro všechny tyto skupiny (s výjimkou amerického kontinentu): všude chyběla a chybí evropská tradice předmoderního národa a další charakteristiky, které činí Evropu Evropou (antické dědictví, křest'anství, reformace, renesance, osvícenství), tedy mravní humanistický odkaz (a obsah) národa. Protagonisté národotvorných procesů v Asii a Africe si prostě přisvojili (možná za vydatného přispění západoevropských teoretiků) evropský termín, který měl pozitivní konotaci, a nijak jim nevadilo, že jim a jejich krajanům chybí evropská historická zkušenost budovaná po generace, ze které realita národa vyrůstala. $\mathrm{S}$ tím bylo následně spjato i vědomí - či chcete-li - mýtus společné minulosti, resp. společného původu.

At’ již tyto nové „,nations“ vznikly díky zápasu proti koloniálnímu útisku či proti útisku despotických monarchů, vždy byly především výsledkem boje o moc, v němž rozhodující roli hrála místní politická a vojenská elita, která se definovala prvotně proti vnějšímu nepříteli. K formování evropských národů cestou národního hnutí samozřejmě také patřil od jistého stádia jejich úspěchu boj o moc. Tento boj však probíhal za práva či zájmy (at' již reálná či fiktivní) již existujícího národa jako kulturní hodnotové pospolitosti, resp. v podmínkách národního hnutí nacházejícího se ve své agitační fázi $\mathrm{B}$. V situacích mimoevropských měl prioritu boj o politickou moc, o vytvoření politické entity „nation“. V tomto boji, kterému vulgarizující zjednodušení bylo uděleno označení „nationalism“, dominovala představa, že stát, který ovládli, resp. budovali, se má prezentovat zároveň jako „nation“.

Shrňme závěrem do několika bodů, v čem je rozdíl mezi národem v Evropě a „nation“ mimo Evropu z hlediska jejich geneze?

- Herderiánsko-romantická představa národa jako hodnoty o sobě

- Etický humanistický postulát obsažený v národní existenci: z identifikace s národem vyplývá závazek práce pro tento národ

- Odtud další postulát: službou národu sloužit lidstvu (společné kořeny těchto dvou etických postulátů někdy spíše v křest’anské tradici, jindy spíše vosvíceném patriotismu)

- Kulturní kvality a kulturní specifika jako jeden ze základů národní existence - opět $\mathrm{s}$ tím, že rozvíjet národní kulturu znamená pomáhat rozvoji kultury celé humanity

- V té souvislosti zbytnost státně-mocenské komponenty národní existence (alespoň ve středoevropské terminologické tradici): je možno si představit národ bez státu, ale nikoli národ bez osobité kultury a bez společného osudu -

- Odtud historický rozměr evropského národa a historismus zdejší národní identity 
- Evropský národ se rodil - až na malé výjimky - v průběhu modernizačního procesu tedy zároveň s úsilím o rovnost lidí, o politické svobody, ale také zároveň s racionalizací, industrializací, urbanizací - v národním sebevědomí se to odrazilo ve stereotypu pokrokovosti národa.

Toto shrnutí by mohlo být pěkným závěrem, ale bohužel by to byl závěr jen dílčí, protože je založen na historické analýze procesu formování národa. Charakterizuje klasický model evropského národa ve 20. století, ale je otázka, zda platí pro dnešek. Globalizace a s ní spojený nástup digitální éry posunuly na novou kvalitativní úroveň nejen cirkulaci a uniformizaci zboží, ale také cirkulaci a glajchšaltaci idejí a stereotypů. Díky této cirkulaci zasáhly globálně deformované termíny „,nation“ a „nationalism“ také Evropu, vrátily se do místa zrodu v devalvované a vyprázdněné podobě. Ponechám stranou problém, který přináší jejich užívání pro rozbor a výklad specificky evropských procesů - to je problém spíše pro jiné odborníky. Zůstanu jen u otázky, jak tento „návrat““ ovlivnil samu evropskou představu o národě a smyslu jeho existence. Co dnes zbylo z oněch vazeb a hodnot, které jsou spjaty s evropským národem 19. století?

- Humanistický imperativ služby své národní pospolitosti dnes už je cizí většině lidí odchovaných neoliberálním individualismem

- Z Zárodního zájmu se stal politický slogan, jehož využívají různé skupiny pro své partikulární zájmy

- Spojení ideje národa s idejí pokroku je zkompromitováno hrůzami, které lidstvu způsobily světové války

- Tradiční historismus jako vědomí společného osudu se rozkládá - byt' u různých národů různě silně

- Jazyk ztratil ve většině zemí postavení hodnoty o sobě, o kterou nutno pečovat, a přestal být symbolem národní svébytnosti

Významnou okolností je, že v době, kdy téměř všechny evropské národy jsou plně formovány, mají plnou sociální strukturu a jejich př́íslušníci považují národní příslušnost za samozřejmou danost, že v této situaci ustupuje do pozadí ona rovina, která pracuje s národem jako abstraktní hodnotovou komunitou, jako s „,ideou“ a národ se častěji, či téměř výlučně sleduje právě v poloze velké sociální skupiny, která je stále více sítí než strukturou. 
Tím vším nemá být řečeno, že identita s národem navždy zkorodovala: pouze ustoupila do pozadí a dostala novou podobu - nejen v souvislosti s globalizací, ale také v neprŕmé závislosti na přechodu k počítačovému věku. Její síla se projevila v některých vypjatých situacích, jako bylo sjednocení Německa nebo rozpad Jugoslávie, projevuje se také jako reakce na ekonomickou krizi v některých zemích, projevuje se v diskuzích o omezování importu spotřebního zboží a podobně - a především žije bouřlivým životem mezi sportovními fanoušky. Společnou charakteristikou většiny těchto projevů přetrvávající identifikace s národem ovšem je, že většina jejích nositelů především očekává a radostně kvitují, když něco výhodného, pro ně př́jemného vyplyne z národního úspěchu, který považují za „svůj““. Národ je zde pro ně, jsou však zde také oni pro národ? Vše nasvědčuje tomu, že jsou ochotni pro svoji národní pospolitost udělat, resp. obětovat mnohem méně než jejich předci. $V$ tomto ohledu se možná již rozdíl mezi evropskou a neevropskou národní pospolitostí vytrácí nebo se dostává do nové polohy. 


\title{
Etnická identita Uruguayců
}

\author{
Ethnic identity of Uruguayans
}

Anna Josková

Universidad de la República, Avenida 18 de Julio 1968, Montevideo, Uruguay

Email: joskovaa@rektorat.czu.cz

DOI: https://dx.doi.org/10.7160/KS.2021.150102

\begin{abstract}
This paper examines Uruguayan society, which, despite its multiethnic origins, has developed a homogeneous culture. The main objective is to define the main cultural elements and describe the attributes of the Uruguayan ethnicity. Based on the analysis of socio-cultural specificities, the thesis provides practical recommendations to facilitate good relations with the Uruguayan nation. These may be particularly useful for business people, potential international students, travelers or other visitors to Uruguay, and others interested in learning about the local people and their culture. The theoretical section explains basic concepts related to identity, ethnicity and nation, and also introduces theoretical concepts and approaches to these ambiguous phenomena. The practical part contains interpreted data from field research conducted by the author in Uruguay in 2018. The research is based on qualitative research methods and consists of two focus group interviews with Uruguayans, four semi-structured interviews with recent immigrants, and long-term observation. The significance of the research is all the more valuable because the findings presented are unique in the field of this previously uncovered topic.
\end{abstract}

\section{Keywords}

Uruguay, ethnicity, identity, culture, nation, qualitative methods, field research, focus group

\section{Klíčová slova}

Uruguay, etnicita, identita, kultura, národ, kvalitativní metody, terénní výzkum, skupinový rozhovor

\section{Úvod}

Práce se věnuje studiu uruguayské společnosti, zkoumá pohledy na skupinu vlastními členy, tedy Uruguayci, a zabývá se i hledisky nedávno příchozích imigrantů, tedy těch, kteří stojí mimo skupinu.

Uruguayci jsou převážně potomci imigrantů, kteří do země v dobách kolonialismu přicházeli z různých důvodů. Právě v této epoše bylo původní obyvatelstvo země z velké části 
vyvražděno a jeho kultura zanikla. ${ }^{1} \mathrm{~V}$ období od první poloviny 19 . století do druhé poloviny 20. století přicházejí v šesti vlnách imigranti převážně afrického, francouzského, španělského, italského, slovanského, arménského, židovského a syrsko-libanonského původu. ${ }^{2}$ Nejen, že se Uruguay krátce po skočení těchto vln stala pokrokovým a ekonomicky stabilním státem v rámci regionu Jižní Ameriky, ale je pozoruhodné, jak si takto různorodá pospolitost národů a etnik během několik desítek let vytvořila jedinečnou a homogenní kulturu a identitu.

V práci jsou představeny hlavní prvky uruguayské kultury, které mají vzhledem $\mathrm{k}$ původu obyvatel kořeny $\mathrm{v}$ mnoha cizích zemích. Tyto různorodé kulturní znaky si $\mathrm{v}$ Uruguayi, i když mnohdy v pozměněné formě, našly své místo. Dále jsou uvedeny atributy uruguayské etnicity, kterými se Uruguayci sebeurčují a identifikují. Na základě analýzy aspektů národního cítění a sociálně-kulturních specifik jsou představena praktická doporučení, která mohou vést k navázání dobrých vztahů s uruguayským národem.

Cílem práce je vymezit etnickou identitu a kulturu Uruguayců, a na základě zjištěných sociálně-kulturních specifik navrhnout doporučení vhodná pro navazování primárně obchodních, ale i dalších vztahů s obyvateli daného národa.

V práci budou popsány prvky a symboly uruguayské kultury, místní zvyklosti, tradice, stereotypy, oblíbená konverzační témata a společenská tabu. Poté budou uvedena kulturněhospodářská specifika, která mohou být prakticky využitelná.

K dosažení uvedeného cíle pomohou odpovědi na tyto výzkumné otázky:

- Jaké jsou atributy uruguayské etnicity?

- Jaké jsou hlavní prvky uruguayské kultury?

- Jaká sociálně-kulturní specifika je dobré znát před př́ijezdem do Uruguaye?

Odpovědi byly zjišt'ovány metodami kvalitativního výzkumu, které umožňují získat hlubší vhled do zkoumaných problematik. Focus group se dvěma skupinami Uruguayců, hloubkové polostrukturované rozhovory se čtyřmi nedávno příchozími imigranty a dlouhodobé zúčastněné pozorování výzkumnice posloužilo k objasnění etnické identity Uruguayců.

\section{Literární rešerše}

Felipe Arocena a Sebastián Aguiar ve své knize Multikulturalismus v Uruguayi uvádí, že Uruguay není tím, co je popisováno $\mathrm{v}$ národní historii, ani tím, co se zobrazuje na

\footnotetext{
${ }^{1}$ ZOUREK, Michal. Uruguay: Stručná historie státu. Praha: Libri, 2015, s. 11.

${ }^{2}$ PI HUGARTE, Renzo a Daniel VIDART. El legado de los inmigrantes - 1. Montevideo: Nuestra Tierra, 1969, s. 16.
} 
mezinárodních prezentačních obrázcích lákajících turisty nebo investory do země, která je europeizovaná, bez indiánů a domorodého dědictví, sekulární, s několika málo černochy a kulturně homogenní. Tato země má podle nich kulturní rozdílnost mnohem větší, než se obecně uvádí. ${ }^{3}$ Autoři předkládají, že přistěhovalci nebyli pouze Španělé a Italové, jak bývá běžně a často uváděno, ale dokazují, že existovaly další důležité kolektivy, které by měly být uznány jako architekti uruguayské národnosti. Švýcaři, kteří se usadili v Nueva Helvecia, zemi odkázali mléčnou kulturu a velkou kapacitu sdružení občanské společnosti, která na úsvitu uruguayské nezávislosti neexistovala; Libanonci začali obchodovat na venkově a neintegrovali se do aktivní politiky; Arméni vybudovali sít' dobře organizovaných institucí, např. škol, církví a rádiových stanic, přinesli lehmeyun ${ }^{4}$ a jména končící na arménské „ian“ jsou často spatřena ve fotbale i politice, tedy dvou „národních vášních“; Rusové ze San Javiera přinesli slunečnicová semínka, a když se objevily první žluté květy na polích, krajané se lekli, že vysázely okrasné květiny; Židé dali život čtvrti Reus v Montevideu, zvané „židovská čtvrt“، a povedlo se jim zbudovat hřbitov La Paz, který jim José Batlle y Ordóñez (prezident Uruguaye v letech 1903-1907 a 1911-1915) dlouhá léta upíral. Jsou komunitou, která s elánem uskutečňuje své rituály a oslavy. Arabové z brazilské hranice Chuy jsou muslimové, kteří mají svou vlastní mešitu, zapojili se do obchodu a pochovávají své mrtvé zabalené do bílých prostěradel přímo do země na svém vlastním hřbitově. Peruánci, kteří dorazili jako poslední a přišli za prací v oblasti rybolovu a domácích služeb, zpochybňují schopnost tolerance, kterou má uruguayská populace před příchodem nových přistěhovalců. ${ }^{5}$

Uruguay, jak analyzovali Cabella a Porzecanski ${ }^{6}$, představuje odlišný historický výchozí bod při tvorbě etnických a rasových kategorií a nastoluje diskusi o tom, co představuje rozmanitost a co diskriminaci. Autoři uvádějí, že Uruguay historicky stavěla na tom, co autoři nazvali národní mýtus o rasové demokracii, homogenitě a rovnosti př́ležitostí. To vše na základě převahy populace evropského původu a úsilí státu o budování vysoce integrované společnosti. Země čelila rostoucím tlakům vyvíjeným afro-uruguayskými organizacemi, což nakonec přispělo k redefinování uruguayské identity. Mýtus rasové homogenity byl v rozporu s řadou sociálních hnutí a etnickými vůdci. Byly publikovány studie, které ukazují empiricky významné socioekonomické mezery mezi afro-potomky a

\footnotetext{
${ }^{3}$ AROCENA, Felipe a Sebastián AGUIAR, ed. Multiculturalismo en Uruguay: Ensayo y entrevistas a once comunidades culturales. Av. Agraciada 3086, Montevideo, Uruguay: Gráfica Don Bosco, 2007, s. 7.

${ }^{4}$ Tradiční arménský pokrm

${ }^{5}$ Ibidem, s. 8.

${ }^{6}$ CABELLA, Wanda; PORZECANSKI, Rafael. The growth of ethnic minorities in Uruguay: Ethnic Renewal or Measurement Problems?. In: Social Statistics and Ethnic Diversity. Springer, Cham, 2015. p. 175-189.
} 
bílými. Statistický růst populace afro-potomků a původního obyvatelstva během posledního desetiletí v Uruguayi podporovalo etnické oživení v důsledku rostoucí legitimity nebílé identity jako prostředku v boji proti diskriminaci. Uruguayský statistický institut zaznamenal mezi lety 1996 a 2006 nárůst afro-potomků z 1,7 \% na 9,1 \% a u domorodého obyvatelstva z $0,8 \%$ na $3,8 \%$ obyvatelstva.

Zourek ve své publikaci Uruguay představuje vedle historie státu hlavní prvky uruguayské kultury. Uvádí, že dlouhá léta udržované zvyky a tradice kreolského obyvatelstva začaly od konce 19. století ustupovat kultuře nově prríchozích imigrantů. I když se zpočátku zdálo, že se venkovský nativismus a městský kosmopolitismus domněle vylučují, první třetina 20. století byla obdobím pozoruhodné symbiózy těchto dvou rozdílných kulturních modelů. Neopomenutelnou úlohu při tom sehrálo usmíření a následná spolupráce dvou tradičních politických stran, které představovaly a zastupovaly zájmy obou skupin. Identita se nicméně nevytváŕí pouze prostřednictvím státní politiky. Podstatná byla vnitřní migrace a kontakt $\mathrm{s}$ přistěhovalci v hlavním městě Montevideu. Příkladem adaptace a ztotožnění přistěhovalců v nové vlasti je rozšíření čajové infuze mate - tradičního nápoje, dále grilování hovězího masa - asado nebo pokrm dulce de leche. Dřívější prostota gaučovského oblečení byla zapomenuta a až jeho nová verze s nádhernými ornamenty se stala „národním krojem“. Zejména na venkově oblíbený tanec z koloniálního období Pericón, se stal národním uměním a neodmyslitelným prvkem školních slavností.

Hudba a tanec candombe, nejvýraznější odkaz černošské populace, se od poloviny 19. století staly nedílnou součástí montevidejského karnevalu. Rytmickou melodii bubnů pocházející z Angoly si Uruguayci rychle oblíbili a záhy si ji zvolili za jeden ze svých kulturních symbolů. Ze zmíněných afrických, italských a španělských rytmů pochází světově proslavené tango. Tento tanec se zrodil koncem 19. století v prostředí nižších sociálních vrstev na předměstí Montevidea a Buenos Aires, přezdívá se mu „tanec smutných slov“ a je typickým příkladem vztahu periferie a města. Nejznámějším skladatelem a také zpěvákem tanga se nepochybně stal Argentinec Carlos Gardel (asi 1887/1890-1935). Přestože nejnovější poznatky ukázaly, že se ve skutečnosti narodil ve francouzském Toulouse, a ne v uruguayském Tacuarembó, Uruguayci se k němu hrdě hlásí. Jinými slovy je tak uruguayský jako mate a tak argentinský jako hovězí biftek. Interpret je známý především svými skladbami Por una cabeza či Volver a jeho popularita trvá i po jeho tragické smrti. Gardel zahynul v roce

\footnotetext{
${ }^{7}$ ZOUREK, Michal. Uruguay: Stručná historie států. Praha: Libri, 2015, s. 49
} 
1935 při leteckém neštěstí v Medellínu, což dalo vzniknout mnohým mýtům, které z něho učinily kult lidové zbožnosti. ${ }^{8}$

U príležitosti stého výročí nezávislosti republiky zaplnily veřejný prostor pomníky. Největší a nevýznamnější je pomník národního hrdiny Artigase na Plaza de Independencia. Navzdory současnému vyzdvihování uruguayské bílé rasy, která v regionu byla prezentována jako jedinečná, v Montevideu vedle bronzové sochy gauča a přistěhovalce nalezneme také černošské nosiče vody či sochu upomínající na poslední indiány Charrúas. Uruguay dala světu řadu významných spisovatelů. Jde např́klad o básníka Julio Herrera y Reisssinga, feministku Delmiru Agustinii, esejistu José Enrique Rodó či spisovatele povídek Horacio Quiroga, jehož některá díla byla přeložena i do češtiny. V Uruguayi bylo a stále je velmi populární divadlo. Právě v Montevideu nalezneme jedno z nejhezčích divadel Latinské Ameriky, Teatro Solís, kde často hostovaly i slavné soubory z Evropy.

Arocena zmiňuje, že jedním z problémů, s nimiž se přistěhovalecké státy potýkají, je spojen s kalendářem svátků a oslav. Data považovaná za posvátná, nebo výročí reprezentující historii národů, jsou základní součástí zachování identit. V každém z těchto jedinečných okamžiků slavnostní rituály aktualizují př́slušnost ke společné historii, a tedy $\mathrm{k}$ etnické skupině nebo národnosti. V Uruguayi nejsou potlačované žádné druhy svátků a oslav kteréhokoli etnika. Avšak stále existují nepř́ímé př̌kážky, které jim v některých případech brání. Např́klad, pokud se ve společenství prokáže posvátný den, kdy se nemůže pracovat, a tento den tak není právně upraven v pracovněprávních předpisech, ten, kdo do zaměstnání nepřijde, může být potrestán, protože jeho odůvodnění nebude uznáno za platné. Proto se židovská komunita snaží o to, aby byl její kalendář prázdnin v Uruguayi uznán za platný. Například v sousední Argentině existuje zákon, který povoluje Židům čtyři nepracovní dny během Velikonoc (Pesach), dva pro Nový rok (Rosh Hashanah) a jeden za Den odpuštění (Yom Kippur). ${ }^{9}$

\section{Etnická identita Uruguayců}

Etnicita je vytvářena prostřednictvím sociálního kontaktu, vzniká vztahem mezi dvěma nebo více skupinami a existuje právě mezi nimi. ${ }^{10} \mathrm{~V}$ praxi není významné, jaké objektivní kulturní rozdíly mezi skupinami existují, ale to, jaké mezi nimi existují vzájemné vztahy. Důležité je

\footnotetext{
${ }^{8}$ ZOUREK, Michal. Uruguay: Stručná historie států. Praha: Libri, 2015, s. 50.

${ }^{9}$ AROCENA, Felipe a Sebastián AGUIAR, ed. Multiculturalismo en Uruguay: Ensayo y entrevistas a once comunidades culturales. Av. Agraciada 3086, Montevideo, Uruguay: Gráfica Don Bosco, 2007, s. 76.

${ }^{10}$ ERIKSEN, Thomas Hylland. Etnicita a nacionalismus: antropologické perspektivy. Praha: Sociologické nakladatelství (SLON), 2012, s. 102.
} 
také to, jak jsou rozdíly chápány těmi, kterých se vztahy bezprostředně týkají. ${ }^{11} \mathrm{Z}$ toho důvodu byla Uruguaycům při skupinových rozhovorech kladena otázka „,Jaké spatřujete rozdíly mezi vámi a Argentinci? “. Porovnání s Argentinci bylo zvoleno kvůli údajně největší podobnosti mezi těmito dvěma národy ${ }^{12}$ a odpovědi na tuto otázku odkryly také vztah mezi nimi. Mnohaleté výzkumy etnických procesů jasně ukazují, že neexistuje žádná př́imá kauzální spojitost mezi kulturní výměnou a rozpadem hranic mezi nejrůznějšími identitami. Často to bývá právě naopak - čím jsou si lidé podobnější, tím více se zabývají tím, jak se odlišit jeden od druhého. A mohlo by se doplnit - čím více se snaží být odlišní, tím více jsou si podobní. ${ }^{13}$

Aby byl zjištěn aspekt etnicity, který zohledňuje pohled na skupinu vlastními členy, tj. jak oni sami sebe vnímají ve vztahu k jiným, byly respondentům položeny otázky „ $V$ čem se citite být jedinečnými? “ a „Na co jste hrdi??“. Aby bylo zjištěno, jak na Uruguayce pohlížejí lidé mimo skupinu, byli dotazováni nedávno př́íchozí imigranti. Jeden z nich žil dříve i v Argentině, proto byl požádán o popsání rozdílu mezi těmito národy. Pro dokreslení celkového obrazu byl písemně osloven rodilý Argentinec, aby i on vysvětlil podobnosti a rozdíly, které vnímá mezi jeho národem a Uruguayci.

\section{Rozdíly mezi Uruguayci a Argentinci}

Uruguayské vnímání odlišností oproti Argentincům je velmi různorodé, přitom se tato škála náhledů opakovala v obou skupinových rozhovorech. Z popisu respondentů vyplývá, že vztah mezi Uruguayci a Argentinci - Porteños (obyvatelé hlavního města Buenos Aires) je napjatý, panuje mezi nimi určitá rivalita, ale přesto jsou si tyto dvě národnosti hodně podobné a velmi blízké. Hned na začátku rozhovorů na toto téma $\mathrm{v}$ obou př́ípadech zaznělo, že je třeba rozlišovat mezi Argentinci - Porteños a obyvateli venkova; ti jsou totiž podle Uruguayců mnohem skromnější a Uruguaycům bližší. Jeden respondent zdůraznil, že Argentina je společnost extrémů - rozdíly mezi chudými a bohatými jsou v zemi velmi výrazné, zatímco v Uruguayi je na tom většina lidí podobně. Dále respondenti popisovali pouze vztah k Porteños, protože s nimi přicházejí do kontaktu nejčastěji. Většina turistů navštěvujících Uruguay je z Argentiny. První názor, na kterém se shodlo několik dotazovaných v obou rozhovorech, byl, že Porteños jsou povýšení, ješitní a přivlastňují si oběma národům společné

\footnotetext{
${ }^{11}$ ERIKSEN, Thomas Hylland. Antropologie multikulturních společností - Rozumět identitě. 1. vydání. Praha: Triton, 2007, s. 68.

${ }^{12}$ ZOUREK, Michal. Uruguay: Stručná historie států. Praha: Libri, 2015, s. 7.

${ }^{13}$ ERIKSEN, Thomas Hylland. Antropologie multikulturních společností - Rozumět identitě. 1. vydání. Praha: Triton, 2007, s. 7.
} 
prvky hmotné i nehmotné kultury, jako je mate, tango, dulce de leche, asado atd. Ale nejen to, také uruguayskou půdu. Uruguay považují za svou 24. provincii (nepočítá-li se jako provincie hlavní město) a chovají se podle toho. Např́íklad podle respondentů Argentinci tvrdí, že turisty nejoblíbenější uruguayské přístavní město Punta Del Este patř́i jim (to zaznělo i v obou skupinových rozhovorech). Porteños o Uruguaycích mluví jako o mladších sourozencích, nazývají je v překladu něčím jako „Uruguayčíky“ s pro ně pozitivní konotací, chovají se k nim povýšeně, a to Uruguayce rozčiluje. Na druhou stranu je podle nich mají rádi, a to víc, než Uruguayci je (toto tvrzení se opět opakovalo). Respondenti uvádějí, že se Porteños povyšují nade všemi národy a jsou tím ve světě proslulí. V obou skupinových rozhovorech zaznělo, že se někomu ze skupiny v zahraničí prrihodila situace, kdy si někdo jiný oddechl, že daná osoba není Argentinec (Porteño), ale Uruguayec. Porteños jsou podle respondentů egocentričtí, hrdí, dokážou se „prodat“ a ze svých slavných osobností dělají bohy. To Uruguayci neumějí, jsou vždy kritičtí i ke svým úspěšným osobnostem (toto tvrzení podporuje tradice kritických Murgas). Podle Uruguayců jsou oni sami mnohem pokornější a skromnější. Zourek ${ }^{14}$ uvádí, že Uruguayci ve snaze rozlišit charakteristiky mezi nimi a Argentinci o sobě v nadsázce prohlašují, že jsou Argentinci bez pocitu nadřazenosti a Argentinci jim oponují, že oni jsou Uruguayci bez pocitu méněcennosti.

V obou rozhovorech několikrát zaznělo, že jsou Uruguayci a Argentinci stejní, ale také naopak, že jsou úplně jiní.

Zajímavě vztah mezi Uruguayci a Argentinci popsala respondentka Lucía: „Vztah mezi Porteños a Uruguayci je typicky sourozenecký. Budeme se nenávidèt, budeme se hádat, ale když se něco stane, podpořime se. Napřiklad v Argentině je problém s potratem (a lidé nosí zelené šátky, aby projevili nesouhlas s jejich zákazem) a tady v Uruguayi vidíš 80 \% lidí se zeleným šátkem. Když se něco stane tam, je to jako kdyby se to stalo tady. Nedávno $v$ Argentině zmizel chlapec, byl to zamlžený př́pad a tady se dělaly demonstrace. Hádáme se, pereme se, ale „když se vaři brambory“ (ustálené slovní spojení v překladu něco jako „když jde do tuhého “) jsme tam, jeden pro druhého, a to platí z obou stran.“

\section{Pohledem Argentince}

Pro Uruguayce a Argentince je stejné všechno související s kulturou Rioplatense. Tím je myšleno: tango (Carlos Gardel), příchod evropských přistěhovalců a afrických otroků, konzumace mate patřící k celému pobřeží a hranici mezi Brazílií, Argentinou, Paraguayí

\footnotetext{
${ }^{14}$ ZOUREK, Michal. Uruguay: Stručná historie států. Praha: Libri, 2015, s. 7.
} 
a Uruguayí, velká spotřeba masa, agroexportní hospodářská politika a Mercosur. Rozdíly jsou v různých nářečích, které národy mají. Podle respondenta má Argentina větší rozmanitost, odlišná nářečí a př́izvuky podle regionů, kterých má mnoho vzhledem ke svému velkému území. To souvisí také s rozdílností podnebí, krajiny a také předhispánské kultury. V Uruguayi je známo pouze etnikum Charrúas, zatímco v Argentině jich je více - Huarpes, Mapuches, Tehuelches atd. Vztah mezi Argentinou a Uruguayí je podle respondenta velmi dobrý. Uruguay a Argentinu popisuje jako sesterské země s velmi podobnou historií, nicméně upozorňuje na jejich odlišné národní hrdiny. Otec vlasti Argentiny je osvoboditel San Martín a otec vlasti Uruguaye je Artigas. Uvádí, že Argentinci jsou velmi vášniví, zejména v politice, náboženství, sportu atd. a mají rádi názor na všechno. Možná jsou Uruguayci diskrétnější a organizovanější. V Argentině je mnoho obyvatel s velmi odlišnými myšlenkami, někdo z Patagonie z jihu je naprosto odlišný od někoho ze severu z Cuyo (Mendoza). To je podle respondenta důvod, proč je Argentince velmi obtížné zorganizovat a proč v zemi došlo k velmi silné občanské válce. Myslí, že v Uruguayi existuje více jednoty.

\section{Pohledem imigranta, který žil v obou zemích}

Na porovnání Uruguayců a Argentinců byl dotázán také respondent Juan - imigrant z Kolumbie, který $\mathrm{v}$ době rozhovoru žil 9 měsíců v Uruguayi a předtím přibližně 9 let v Argentině. Ten popsal metaforicky Uruguay jako malý národ, který trpí pocitem, že je mladší sourozenec Argentiny a nemůže se s tím vyrovnat. „Přijde mi, že Uruguay má pocit, že je mladši sourozenec a tím nechce být. Vždycky ale bude ve stínu gigantické Argentiny.“ Uvedl, že v Uruguayi je společnost homogenní, zatímco v obrovské Argentině je to, co kraj, to jiná kultura. Podle něj právě proto, že má Argentina tolik rozličných krajů, bere Uruguay jako svoji 24. provincii. Vnímal, že Uruguayci trpí tím, že nejsou ve světě rozeznáváni, že lidé nevědí, kde Uruguay leží, přitom o Argentině každý někdy v životě slyšel. Zároveň mu připadá, že jsou Uruguayci hrdí na to, že jsou Uruguayci. „Myslím si, že oni se cití být hrdí na to, že jsou malá země, ale zajímavá. Oni ti to neřeknou, ale přijde mi, že si jsou vědomi a jsou hrdi na to, že mají dobrý fotbalový tým, který na světových pohárech hraje vždy výborně, a že $v$ Latinské Americe mají jednu z nejlepšich ekonomických stabilit. Věř́m, že diky tomuhle se cití dobře." Podle něj Argentinci Uruguayce zbožňují, ale Uruguayci Argentince (Porteňos) pomlouvají a kritizují. Zároveň Argentince nezajímá, co si Uruguayci myslí, protože oni kritizují všechno. „Uruguayci Argentince pomlouvaji, ale to Argentinec Uruguayce nikdy pomlouvat nebude, Argentinci zbožňuji Uruguayce." Nakonec dodal, že Argentince celkově 
nezajímá vůbec, co si kdo myslí, ale Uruguayce ano. Uruguayce vnímá jako velmi klidný lid, s dobrou vibrací, veselejší a optimističtější než Argentince. Argentinci jsou podle něj hodně hluční, přirovnal to ke stereotypu Italů. Přiznal, že ani on se španělštinou jako svým rodným jazykem, Argentincům ze začátku svého pobytu nerozuměl, protože všichni slangově mluví ve stejnou chvíli, jeden přes druhého a nelze pochytit, co kdo ř́ká. V Argentině je podle něj cítit špatná nálada ze současné hospodářské situace, protože na tom země není ekonomicky dobře a už není Paříží Jižní Ameriky. Tvrdí, že v Uruguayi je pití mate rozšiřrenější a grilované hovězí chutnější.

\section{Jedinečnost}

Existuje množství kulturních rysů zcela zjevných nebo skrytých v každodennosti, které bývají pro určité etnikum jedinečné. Bart se vymezuje vůči předpokladu kulturní jedinečnosti etnických skupin. Tvrdí, že užitečnější je na specifickou sdílenou kulturu nahlížet jako na výsledek dlouhodobého sociálního procesu, nikoli jako na primordialistickou vlastnost. Zdůrazňuje důležitost studia etnických hranic, které mají být definované zevnitř, z perspektivy jejich členů. ${ }^{15}$ Mnohé kulturní rysy často přesahují etnické hranice, důležité ale je to, že danou kulturu její nositelé považují za svébytnou. ${ }^{16}$

V následující kapitole budou uvedeny odpovědi respondentů na otázku „V čem se citite být jedinečni", která předpokládala nastínění oněch etnických hranic, toho, v čem se Uruguayci cítí být odlišní ve vztahu k ostatním.

Odpovědí na tuto otázku v rozhovorech nezaznělo mnoho, ale opět se v obou př́padech jedna odpověd’ opakovala, a to „že jsme směsice“. V jednom z rozhovorů to bylo doplněno vysvětlením, že i když jsou Uruguayci směsice (imigrantů, resp. potomků imigrantů) jsou poměrně homogenní, ve smyslu, že základní zvyky a tradice sdílejí všichni napříč celou zemí. Vymezili se tím opět vůči Argentincům tvrzením, že u nich jsou kultura a zvyky na severu země naprosto odlišné od těch na jihu země, zatímco v Uruguayi existuje určitý ,základ“, který sdílejí všichni její obyvatelé. V této souvislosti respondenti přiznali, že stále bojují za to, aby byli rozeznáváni ve světě. Trpí tím, když v zahraničí řeknou, že jsou z Uruguaye, a lidé nevědí, kde to je. V této souvislosti kdosi zmínil, že to je proto, že pocházejí ze zemí třetího světa. Toto neaktuální dělení světa je svým způsobem v jejich prostředí stále přitomné, protože k jeho vyjádření došlo během terénního výzkumu

\footnotetext{
${ }^{15}$ ERIKSEN, Thomas Hylland. Etnicita a nacionalismus: antropologické perspektivy. Praha: Sociologické nakladatelství (SLON), 2012, s. 73.

${ }^{16}$ TESAR̆, Filip. Etnické konflikty. Praha: Portál, 2007, s. 24.
} 
mnohokrát. Informátoři věří, že mate a fotbal jsou jediné atributy, podle kterých je svět identifikuje. Od jednoho respondenta zaznělo, že Uruguayci jsou jedineční hraním na candombe, uměním karetní hry truco a dobrými mravy.

\section{Hrdost}

Podle studie Jessicy Tracyové a Richarda Robinsona je hrdost důležitá emoce, která hraje významnou roli v mnoha oblastech psychického fungování. Pocit hrdosti posiluje prosociální a adaptivní chování, a naopak její ztráta může vyvolávat agresivitu nebo nespolečenskost. Jejich výzkum ukazuje, že vystupování a chování s hrdostí spojené je univerzální ve všech kulturách bez ohledu na etnicitu či zeměpisnou šiřku a délku. Podle nich také postoje vyjadřující sebejistotu a hrdost zajišt'ují jedinci významné postavení na sociálním žebříčku, a to výrazněji než projevy ostatních emocí. ${ }^{17}$ Je možné, aby právě to, na co se cítíme být hrdí, formulovalo naši identitu?

V následující kapitole budou uvedeny konkrétní skutečnosti, na které se respondenti cítí být hrdí, jako potencionální aspekty etnické identity.

Řada respondentů uvedla, že se cítí být hrdá na uruguayskou politiku a sociální zákony. Uruguay je jako jedna z mála zemí Jižní Ameriky sekulární stát a zákony zde nepodléhají náboženské tradici, což jsou skutečnosti, které respondenti také zmiňovali. Prvním př́kladem uvedených sociálních zákonů je zákon o potratu. ${ }^{18}$ Uruguay, Guayna a Francouzská Guayna jsou jediné země Jižní Ameriky, kde je zákonem povolen umělý potrat bez podmínek (napřr. nechtěné těhotenství) v prvních týdnech těhotenství (Aborto en América Latina). Uruguayci si dobře uvědomují svou jedinečnost v rámci regionu a zároveň podporují ostatní země v jejich snahách tento zákon prosadit. Konkrétně, jak již bylo zmíněno, Uruguayci na podporu Argentinců nosí viditelně zelený šátek, což je v Argentině symbol podpory zákonu o potratu (Los pañuelos verdes). Dalším řešeným zákonem je zákon o transosobách, který umožňuje právo na svobodný rozvoj osobnosti podle své vlastní genderové identity, bez ohledu na své biologické, genetické, anatomické, morfologické, hormonální nebo jiné přiřazení. ${ }^{19}$ Zmíněn byl také zákon o legalizaci marihuany. Uruguay se

\footnotetext{
${ }^{17}$ TRACY, Jessica L.; ROBINS, Richard W. The psychological structure of pride: a tale of two facets. Journal of personality and social psychology, 2007, 92.3: 506.

${ }^{18}$ Ley N ${ }^{\circ}$ 18.987: INTERRUPCIÓN VOLUNTARIA DEL EMBARAZO [online], 2012. [cit. 2019-10-14].

Dostupné z: https://parlamento.gub.uy/documentosyleyes/busquedadocumentos? $=\&$ Searchtext $=$ aborto\&Chkleyes $=1$

${ }^{19}$ Ley N ${ }^{\circ}$ 19684: LA LEY INTEGRAL PARA PERSONAS TRANS [online], 2018. [cit. 2019-10-14]. Dostupné z: https://www.impo.com.uy/bases/leyes/19684-2018
} 
stala první zemí na světě, která legalizovala prodej a pěstování marihuany v plném rozsahu. ${ }^{20}$ Byl přijat zákon, který upravuje, výrobu (která bude kontrolována státem), uvádění na trh, držení a rekreační a léčivé použití marihuany, jako i použití pro průmyslové účely. ${ }^{21} \mathrm{~S}$ těmito zákony je spjato jméno uruguayského exprezidenta Josého Mujicy ${ }^{22}$, za jehož vlády byly přijaty. Jeho jméno bylo také zmíněno při debatě o atributech hrdosti, ale z reakcí ostatních bylo patrné, že ne všichni mají na jeho osobu stejný názor. Zmínka o něm padla v obou skupinových rozhovorech, přičemž $\mathrm{v}$ jednom príípadě bylo přímo řečeno, že si respondent nepřeje, aby tímto začal debatu o politice, v druhém případě jméno Mujicy vyvolalo vlnu nesouhlasných poznámek. V souvislosti s ním ještě zaznělo, že během několika málo let (myšleno za období jeho vlády) se politika země velmi rozvinula. Pokud jde o politiku, Uruguayci jsou hrdí na to, že jsou jednou z nejméně zkorumpovaných zemí ve srovnání se sousedy z Jižní Ameriky, a že jsou zemí bez válek. „Nejsme zkorumpovaná země, nějaká korupce tady je, ale ve srovnání s ostatními to není nic. “ (Gonzalo, 25 let)

Dva nedávno příchozí imigranti vnímají Uruguayce jako hrdé na to, že jsou Uruguayci. Podle nich si dobře uvědomují, že přesto, že jsou v regionu Jižní Ameriky malá země, jsou ekonomicky nejstabilnější, mají rádi krajinu své země a vědí, že mají výborný fotbalový tým. Podle španělské imigrantky, která v Uruguayi pracuje jako novinářka, zpívají Uruguayci při všech oficiálních a státních akcích velmi hrdě svou hymnu. Říká, že je vnímána nacionalisticky, i přesto, že sami dobře vědí, že v zemi nefunguje vše, tak jak má. Uvedla také přiklad toho, jak mají Uruguayci rádi svoji zemi: „Mají hodně rádi svou zemi, jsou schopni tě ujištovat, že Punta del Este je to nejkrásnějši místo na světě!! " (Sarah, 31 let)

Další oblast, ve které jsou Uruguayci podle nich samotných jedineční a na co jsou hrdí, je veřejné vzdělávání, a to hlavně vysokoškolské. Prý je to ale ostatními státy Jižní Ameriky zneužívaná výhoda a jejich sousedé přijíždějí do Uruguaye vystudovat a pak zemi zase opouštějí. Jeden informátor to komentuje slovy: „Taky je to špatný, protože přicházi mnoho imigrantů vystudovat a pak odjedou, využijí nás a zmizí. Stát by měl vymyslet nějako dohodu, aby to takhle nebylo." (Juliana, 24 let)

\footnotetext{
${ }^{20}$ Uruguay legalizó la producción de marihuana [online], 10. 12. 2013. [cit. 2019-10-14]. Dostupné z: https://web.archive.org/web/20140108112840/http://www.elpais.com.uy/informacion/marihuana-ley-senadouruguay-parlamento.html

${ }^{21}$ Ley N ${ }^{\circ}$ 19.172: MARIHUANA Y SUS DERIVADOS [online], 2014. [cit. 2019-10-14]. Dostupné z: https://parlamento.gub.uy/documentosyleyes/busqueda-documentos? $=\&$ Searchtext=marihuana\&Chkleyes $=1$

22 José Alberto Mujica Cordano byl uruguayský prezident v letech 2010 - 2015, předtím byl dlouhodobě vězněn za své partyzánské aktivity s revoluční organizací Tupamaro (Murray).
} 
Zmíněna byla také uruguayská kuchyně, hlavně maso a domácí a př́rodní produkty (zavařeniny apod.), které jsou na uruguayském venkově standardem. Významnou záležitostí, na kterou se Uruguayci cítí být hrdí, je fotbal, kterému je věnována celá následující kapitola.

Dále zazněly atributy, které nebyly blíže specifikovány, a to príroda, pláže, vesnice, hudba, vědci, spisovatelé, výzkumníci...

\section{Fotbal}

Fenomén, který se bezesporu výrazně zapsal do formování uruguayské národní identity, představuje fotbal. Tento sport do země pronikl v průběhu 19. století prostřednictvím britských námořníků, kteří se jím na pevnině bavili. Úspěchy domácí fotbalové reprezentace, která má díky světle modrým barvám svých dresů přezdívku selección celeste (nebeský výběr), byly značně ovlivněny politickou a ekonomickou stabilitou země. ${ }^{23}$

Jedna informátorka uvedla že, dívčí jméno Celestina bývá favoritem pro novorozené dívky právě v období úspěchů domácího týmu při světových zápasech.

První mezinárodní úspěch zaznamenal národní tým v roce 1924, když na olympijských hrách v Pařiži získal zlaté medaile. Svůj triumf dokázali Uruguayci následně obhájit o čtyři roky později v Amsterdamu. Tyto dvě sportovní události jsou pokládány za neoficiální světové šampionáty. Uruguay se také stala mnohonásobným šampionem Jižní Ameriky. Důležitý úspěch však znamenalo vítězství na prvním oficiálním mistrovství světa v roce 1930, které hostila právě Uruguay. Uspořádání takové akce byla pro Uruguay př́ležitost prezentovat se světu jako stabilní a perspektivní země, čímž se odlišuje od zbytku regionu. Zároveň se šampionát měl stát vyvrcholením oslav stého výročí nezávislosti země. ${ }^{24}$

Uruguayci přijímali fotbalové úspěchy s nadšením. Sportovní úspěchy znamenaly také velký politický triumf vlády. Nová imaginace se do uruguayské společnosti dostávala prostřednictvím rozsáhlého systému zpráv, symbolů a mýtů, a to hlavně od poloviny druhého desetiletí do počátku třicátých let. ${ }^{25}$

Respondenti popisovali, že když hraje reprezentace, lidé se změní, všichni jsou spolu, všichni to společně prožívají. Scházejí se na náměstích a dívají se na plátna, zavírají se obchody, do kanceláří se kupují televize a zaměstnavatelé nechávají sledovat zápas své zaměstnance - celá země se spojí. Lucía vysvětluje: „V tu dobu všichni slavíme, všichni trpíme, všichni se smějeme, všichni jsme stejni. “

\footnotetext{
${ }^{23}$ ZOUREK, Michal. Uruguay: Stručná historie států. Praha: Libri, 2015, s. 47.

${ }^{24}$ Ibidem.

${ }^{25}$ ACHUGAR, Hugo a Gerardo CAETANO, 1992. Identidad uruguaya: mito, crisis afirmación?. Montevideo, Uruguay: Ediciones Trilce, s. 81.
} 
Fotbalové tituly pomáhaly malému státu získávat potřebné sebevědomí a působily mimořádně pozitivně na vládou podporovanou politiku integrace. Značný význam měl také fakt, že několik hráčů bylo černé pleti. ${ }^{26}$

Zde je na místě zmínit uruguayské fotbalové zvolání nebo pobídku „Garra Charrúa“, která funguje jako jakási hnací síla uruguayských hráčů, aby udělali vše, co je v jejich silách ke kýženému úspěchu. Pochází ze slov garra, což znamená dráp, který by měl podle respondentů symbolizovat výdrž, kuráž nebo vnitřní sílu. Význam výrazu Charrúa, což je název původního domorodého obyvatelstva Uruguaye, není jednoznačný. Informátorka vysvětlila, že Charrúas byli svobodní, temperamentní, neklidní, bojovní domorodí obyvatelé Uruguaye, kteří odolávali mnoha útokům, ostatní se jich velmi obávali a oni vždy bojovali až do posledních sil. Jejich jméno je zahrnuto v této frázi právě proto, aby v hráčích vyvolalo zmíněné charakteristiky.

Náměstek ministra sportu říká, že fotbal je v Uruguayi velmi důležitou součástí identity její populace. První triumfy v Copa América, na olympijských hrách a světových pohárech vedly ke sjednocení společnosti, která byla $\mathrm{v}$ prvních letech dvacátého století plná přistěhovalců $z$ různých částí světa. ${ }^{27}$

K dalšímu velkému úspěchu došlo v roce 1950, kdy selección celeste nečekaně porazila Brazílii. Úspěch se postupně transformoval v národní trauma, nebot' se na něj již nepodařilo navázat. ${ }^{28}$ Přesto, jak uvádí jeden informátor, i když se reprezentace umístí na čtvrtém místě, celá země ji při návratu domů vítá jako vítěze.

\section{Kultura}

V literatuře se kultura často dělí na hmotnou a nehmotnou, což je v některých př́ípadech poněkud zavádějící a následující kapitola ukáže proč. Bude v ní představeno několik materiálních kulturních prvků, které jsou však neodmyslitelně spjaty s nehmotným kulturním vyjádřením, zvyklostí nebo tradicí. Nabízí se otázka, zda vůbec existuje nějaký kulturní předmět, který sebou žádné nehmotné kulturní vyjádření nenese.

V následující kapitole budou popsány hlavní prvky uruguayské kultury, které respondenti považovali za důležité a vyprávěli o nich. Některé jako tango a gaucho byly pouze zmíněny, ale nebyly blíže popsány.

\footnotetext{
${ }^{26}$ Ibidem.

${ }^{27}$ ANFITTI, Federico. Garra charrúa, sello uruguayo de origen deportivo reconocido a nivel mundial [online]. Montevideo, 2018 [cit. 2021-01-16]. Dostupné z: https://www.efe.com/efe/cono-sur/cronicas/garra-charruasello-uruguayo-de-origen-deportivo-reconocido-a-nivel-mundial/50000803-3598294

${ }^{28}$ ZOUREK, Michal. Uruguay: Stručná historie států. Praha: Libri, 2015, s. 47.
} 


\section{Mate}

Mate je nápoj vyrobený louhováním „yerby mate“ (dehydratovaných a rozdrcených listů Cesmíny paraguayské). Tato čajová infuze má díky obsahu kofeinu povzbuzující účinek, což z ní činí obzvláště osvěžující nápoj. Příprava stimulačních a léčivých nápojů vychází z tradice domorodého obyvatelstva Guaraní. ${ }^{29}$

Zatímco v Evropě převládala čajová kultura, mate se rozšiřovalo v Jižní Americe. Původně bylo společníkem osamělých farmářů skotu. Divoký, hořký a zelený čaj byl věrný průvodce $\mathrm{v}$ dobách samoty i časů radosti. Jak plynul čas, mate se dostalo do měst po celé Uruguayi, Argentině, Paraguayi a Brazílii (jih země) a stalo se symbolem každodennosti. ${ }^{30}$

Yerba mate čaj kromě jiného obsahuje i vysokou hladinu vitamínu A, působí močopudně a rozšiřuje cévy. Stejnojmenný název nese i speciální nádoba, která se „yerbou mate“ plní, opakovaně zalévá horkou vodou a tento výluh se poté konzumuje. ${ }^{31}$

Konzumace mate nese různé významy podle času, místa, události nebo osoby, s níž je sdíleno. Důvod jeho pití může být také jen potlačení chuti k jídlu, nebo ukrácení času. Mate doprovází studenty během jejich studia, setkání s rodinou a přáteli nebo spolupracovníky. Je to společenský prvek a symbol vřelého přivítání pro návštěvníky země. Mate je obvykle sdíleno a zvykem je používat stejný hrnek a stejnou bombillu (speciální brčko se sítkem). Předávání mate od jedné osoby ke druhé, je velmi dobře odděluje od jiných infuzí, jako je čaj nebo káva. ${ }^{32}$

Mate je jednou ze symbolických a společenských tradic uruguayské kultury a je neoddělitelným společníkem Uruguayců. Pro Uruguayce je typické, že nosí mate společně s termoskou plnou horké vody u sebe během celého dne. Termoska umožnila této tradici překročit hranice domova, a tak se z tohoto rituálu stal životní styl, který je viditelný všude ve veřejném prostoru. Právě termoska představuje podle respondentů významnou odlišnost od způsobu konzumace mate v Argentině nebo na jihu Brazílie. Tam se sice s konzumací tohoto nápoje lze také setkat, ale většina spotřebitelů jej podle respondentů užívá doma a na ulici Argentince tak často s mate v ruce a termoskou v podpaží nepotkáte. „Ten, kdo s sebou nemá mate přes den, se těši celý den až prijide domu a dá si ho.“ (Lucía, 24 let) Ten, kdo mate

\footnotetext{
${ }^{29}$ DELLACASSA, E., CESIO, V., VÁZQUEZ, A., ECHEVERRY, S., SOULE, S., FERREIRA, F., HEINZEN, H. Yerba mate. Historia, uso y propiedades. Revista de la Asociación de Química y Farmacia del Uruguay, 2007, 51: 16-20.

${ }^{30}$ Mate [online], 2012. Ministerio de Turismo del Uruguay [cit. 2019-09-10]. Dostupné z:

https://turismo.gub.uy/index.php/en/uruguay-is/item/1382-mate

${ }^{31}$ Ibidem.

${ }^{32}$ Ibidem.
} 
připraví, ho také většinou během dne sdílí se svými kolegy, známými nebo spolužáky. Podle rozhovorů je sdílení mate nepsaná povinnost. Horké mate pijí Uruguayci během celého roku bez ohledu na roční období a vozí si ho sebou i na dovolenou.

„Až ti Uruguayec nabídne mate, znamená to, že tě bere.“ (Tamara, 24 let)

\section{Karneval - Carnival}

Uruguayský karneval je nejdelší karneval na světě. Začíná na konci ledna a trvá do poloviny března. Po více než 50 dnů se odehrávají pouliční přehlídky a vystoupení plné barev a radosti. Zahájení karnevalu se odehrává v Montevideu úvodním průvodem na Avenidě 18 de Julio, kterého se účastní všichni aktéři slavností, doprovázeni alegorickými vozy a karnevalovými královnami. $^{33}$

Přehlídka se hýbe, desítky tisíc diváků vibrují silou Candombe, které se vyznačuje dialogem tř́ typů bubnů: chico, repique y piano. Nikde na světě prý nelze slyšet více než 2000 bubnů hrajících najednou. Nechat se unést tímto rytmem prohlášeným za světové kulturní dědictví je pro návštěvníky nevyhnutelné. Přehlídka, která pro svou jedinečnost vzbuzuje největší zájem cizinců je ,prohlídka výzev‘, která evokuje setkávání černošských otroků, kteří se v 18. až 19. století mohli shromažd'ovat pouze mimo město. Další nutností je zažít vystoupení Murga, jedno z nejprestižnějších projevů uruguayské kultury, které je podrobněji je popsáno vkapitole 5.3.2. Murga. Během teplých únorových nocí procházejí tyto karnevalové skupiny sousedstvími a soutěží v oficiální karnevalové soutěži, kde prezentují humor a satirují svou vizi země a světa. Činí tak pomocí několika sborových aranžmá, nápadných kostýmů a kreativního líčení. Parodistas, Magazines, Humoristas a Lubolos, jsou další z malebných výrazů, které si lze vychutnat v soutěži na montevidejských jevištích. Kromě hlavního města Montevideo mají všechna města v zemi svou zahajovací přehlídku, každé s vlastními zvláštnostmi. V pohraničních městech, jako jsou Rivera, Artigas a Melo přehlídky přijímají více prvků brazilského karnevalu. ${ }^{34}$

Respondenti popisovali období karnevalu jako oblíbenou část kalendářního roku. Vyprávěli, že i někteří zaměstnavatelé jsou v tomto období shovívavější k výkonům svých zaměstnanců, protože tuší, že mnoho z nich místo odpočinku tráví večery a noci sledováním karnevalových vystoupení. Ty obvykle začínají až kolem osmé hodiny večer a končí kolem druhé hodiny ranní. Respondenti vyprávěli, že se obvykle dostanou domů až kolem třetí až

\footnotetext{
${ }^{33}$ Carnaval [online] Ministerio de Turismo del Uruguay, 2012 [cit. 2019-09-17]. Dostupné z: https://turismo.gub.uy/index.php/uruguay-es/uruguay-es-carnaval 34 Ibidem.
} 
čtvrté hodiny ráno. „Na tribunách uvidíš lidi v obleku v jednu hodinu ráno, jako kdyby nic. Je to období roku, kdy všichni vědí, že všichni spíme málo, protože si uživáme karneval.“ (Lucía, 24 let) Ten, kdo nesežene lístky na tribunu, poslouchá alespoň hudbu v parcích nebo se dívá na prŕmý přenos doma $\mathrm{v}$ televizi. Kdo nestihne ani to, může se podívat další den na opakování. Místní mají karneval velice rádi a respondenti několikrát zdůraznili, že se jedná o nejdelší karneval na světě. „Náš karneval je ten nejdelši na světě, ne ten brazilský!““

\section{Sociálně-kulturní specifika}

To, zda dialekt, způsob odivání, víra nebo zvyklosti, jimiž se řídí obchodování, utvářejí, stimulují či posilují národní identitu, závisí na politice daného státu přinejmenším stejnou mérou jako na tom, jak lidé mluví, jak se oblékají, nebo i na tom, jak se modli. ${ }^{35}$

Existuje množství kulturních rysů skrytých v každodennosti, které mohou být pro určité etnikum jedinečné. Patři sem např́iklad způsob pozdravu, konverzace, dávání spropitného či seznamování. ${ }^{36}$

Většina lidí v Uruguayi se identifikuje jako Uruguayci, což je silně spjato s kulturou. Součástí této kultury je její inkluzivita (je velmi otevřená a téměř každý občan země je vítán tak, aby byl považován za „Uruguayce“, bez ohledu na jeho etnicitu). Tato identita ve své politické definici v podstatě odděluje obyvatele Uruguaye od sousedů, jako je Argentina a Brazílie. Národní identita umožňuje zahrnout do této definice každého, kdo je občanem, bez ohledu na svou kulturu. Tato identita je založena na životním stylu lidí, přičemž jídlo a socializace mají tendenci diktovat, co to znamená být Uruguaycem a jak se má Uruguayec chovat a jednat. Spolu se stravou přichází socializace a důležitost rodiny a přátel, což je další hlavní faktor přispívající k definování identity. Ten zahrnuje vše od jednoduchého rozhovoru, přes sledování nebo hrání fotbal až po slavení svátkư. ${ }^{37}$

V této kapitole budou popsány prvky každodennosti Uruguayců, které byly zjištěny na základě dlouhodobého terénního výzkumu.

\section{Tradice a zvyky}

Bezpochyby nejvýznamnějšími uruguayskými tradicemi a zvyky jsou sdílení infuze mate a grilování asado. Respondenti uvedli, že tradice sdílení mate je pro ně něco tak běžného, že

\footnotetext{
${ }^{35}$ GREW, Raymond. Konstrukce národní identity. In: HROCH, Miroslav. Pohledy na národ a nacionalismus:

Čitanka texti̊. Praha: Sociologické nakladatelství, 2003.

${ }^{36}$ TESAŘ, Filip. Etnické konflikty. Praha: Portál, 2007, s. 19-24.

${ }^{37}$ Culture \& Identity of Uruguay [online], 2013. [cit. 2019-11-07]. Dostupné z:

http://www.safaritheglobe.com/uruguay/culture/
} 
jim to ani nepřipadá jako zvláštní rituál. Vánoční večeři tráví Uruguayci v rodinném kruhu a pořádají asado, tj. grilují.

Ojedinělou uruguayskou novodobou zvyklostí jsou takzvané „posuvné“ svátky - to v praxi znamená, že když státní svátek vychází na středu, den volna se posune na pondělí nebo pátek, aby vznikl prodloužený víkend. Podle respondentů státních svátků v Uruguayi mnoho není. Naproti tomu mají 20 dnů dovolené, což je podle nich v rámci Latinské Ameriky výjimečně mnoho.

Respondenti zmínili místní zvyk stávek, který byl v dřivějších dobách velmi intenzivní a je v zemi dodnes, i když už ne v takové míře, stále aktuální. Stávky již nejsou tak rozsáhlé a dlouhé jako dříve, stále se ale jednodenní stávky konají.

Karetní hra „truco“ je podle respondentů typickou uruguayskou hrou, i když ne všichni z nich si pamatují její komplikovaná pravidla.

Tradičními jsou také různé sporty na koních, především koňská rodea - jineteada, podle respondentů gauchovská aktivita. Jedním z uruguayských národních symbolů je gaucho - statečný jezdec a venkovský chovatel dobytka, který je do dnešní doby žijící legendou. V hlavním městě Montevideu se každoročně pořádá, na kterou se sjíždějí chovatelé z celé země a vystavují nejrůznější plemena dobytka. Součástí této výstavy jsou právě koňská rodea. Respondenti uvedli, že se na výstavu chodí dívat, i když je dobytek tolik nezajímá.

Další tradice, která již byla zmíněna, jsou Velikonoce - Semana Santa, tak ji nazývají věřící, pro ostatní je to Semana de Turismo - týden turismu, kdy mají studenti prázdniny.

Za další častý zvyk považují scházení se v rodinném kruhu nebo s přáteli a společné sledování fotbalu s picadou - drobné občerstvení (oříšky, chipsy apod.).

Neděle je pro Uruguayce „svatým“ dnem, který tráví s rodinou a nic nedělají.

\section{Stereotypy}

Sociální historik Grew ${ }^{38}$ ř́ká, že ideologie identity nejenom ospravedlňuje zavedený politický a sociální systém (ve skutečnosti mohou představovat také základ požadavku změny), ale také jisté chování se vymezuje pro danou národnost jako charakteristické (at' už je méně nebo více žádoucí). Tyto hodnoty pojetí etikety podávané v literatuře, v obrazech, kázáních atd. schvalují určité veřejné role a ovlivňují chování. Pomáhají formovat národní identitu a vytvářet rozdíly stylu, z nichž čerpají představy národního charakteru.

\footnotetext{
${ }^{38}$ GREW, Raymond. Konstrukce národní identity. In: HROCH, Miroslav. Pohledy na národ a nacionalismus: Čitanka texti̊. Praha: Sociologické nakladatelství, 2003, s. 214.
} 
Britský antropolog Cohen, zabývající se tématem sociálních hranice, říká, že je důležité zkoumat, co konkrétní hranice pro skupinu znamenají a jaký význam jim skupina přisuzuje. ${ }^{39}$ Stejně tak důležitý může být výzkum stereotypů, které sami sobě členové skupiny připisují a ty budou popsány v následující kapitole. Zajímavý je nepochybně i pohled nečlenů skupiny, který bude v kapitole také představen.

\section{Stereotypy o Uruguaycích}

Respondenti sami sobě během rozhovorů připisovali různé charakteristiky a vlastnosti. Konkrétně o sobě říkali, že jsou melancholičtí, nostalgičtí, sympatičtí, plaší, konzervativní, zajímající se a dobře pečující o druhé. Zájem a péče o druhé byl jedním respondentem vysvětlen tím, že mnoho Uruguayců pracuje ve službách, a tak jsou zvyklí starat se o druhé. Respondenti mluvili o rodičích, kteří často vyprávějí, jak když byli mladí, bylo všechno jinak, domy se nemusely zamykat atd. Během toho sami respondenti zavzpomínali na „staré časy“, kdy ještě měli haléřové mince a jak bylo vše levné. V předvečer státního svátku nezávislosti země slaví Uruguayci Nostalgickou noc (Noche de la Nostalgia). Během tohoto večera se hraje na všech radiových stanicích a diskotékách nostalgická hudba - oldies, lidé se oblékají v retro stylu, scházejí se s prááteli a vzpomínají. „Uruguayci jsou hodně nostalgičtí, žijí minulostí, jsou melancholičtí a často ríkají, že dřriv se žilo lépe.“ (Josefina, 26 let)

Typické uruguayské chování je podle respondentů stěžovat si, vzpomínat na staré dobré časy, řešit fotbal. „Uruguayec si bude stěžovat na všechno. Bude si stěžovat, když je rozbitá silnice, pak si bude stěžovat, když ji budou opravovat a až bude opravená, najde na ní něco, co je špatně.“ (Lucía, 24 let)

Jedna z respondentek uvedla, že když se ve společnosti řeší nové rozporuplné, a přitom zdánlivě trvalé téma, Uruguayci se k němu obvykle zprvu staví negativně a nechtějí ho přijmout. To podle výpovědi do chvíle, dokud nepřijde bod zlomu, od kterého je to pro Uruguayce vyřešená záležitost (hotová věc) a už se tím nezabývají. Respondentka vysvětlovala, že si Uruguayci zvykají rychle, i když je to ze začátku stojí úsilí a obvykle je to doprovázeno kritikou.

Uruguayci jsou podle nich samých velmi přizpůsobiví, tvární a mnohostranní a to, jak v dobrém, tak ve špatném slova smyslu. Když něco nefunguje, stěžují si, pak si zvyknou a už jim to ani nepřijde. Jeden respondent uvedl, že jsou pohodlní, chybí jim disciplína a často nemají motivaci a chut' na sobě pracovat a zdokonalovat se. Popisoval jejich průměrnost a

\footnotetext{
${ }^{39}$ COHEN, Anthony P. Symbolic Construction of Community. Routledge, 1985, s. 12.
} 
uspokojení s tím, co mají. Uruguayskou společnost vnímá jako klidnou, ve které si lidé zařídí to základní a pak žijí v klidu.

Podle dalšího respondenta je typickým uruguayským mentálním nastavením touha získat práci ve veřejné správě. Důvodů k tomu mají hned několik: „,(..)pracuje se od pondělí do pátku, vydělávají se dobré penize a člověk má jistotu, že o práci neprijide. To znamená práci na celý život, když chce něco jiného, odejít může, ale je velmi těžké, aby ho vyhodil zaměstnavatel. Lidé si myslí, že kvưli tomu tam zaměstnanci nemusejí nic dělat, a pomlouvají je kvůli tomu.“" (Gonzalo, 25 let) Podle respondenta to není pravda a je tam práce hodně. Podle jiného respondenta pracuje většina Uruguayců pro státní správu.

Podle další respondentky jsou Uruguayci „výhodáři“ a rádi využívají všeho, čeho využít mohou.

Uruguayci se celý den těší, až přijdou domů, svléknou si pracovní oblečení, udělají si pohodlí, dají si mate a pustí si televizní noviny. Několik respondentů potvrdilo, že mnoho Uruguayců od 19,00 h do 21,00 h sleduje televizní zprávy. Všechny televizní noviny běží ve stejný čas a vysílají o stejných tématech. Uruguayci mají na každé téma svůj oblíbený kanál.

Uruguayci žijí v noci. Respondenti informaci doplnili příkladem, že v jiných zemích diskotéky zavírají v jednu hodinu ráno, zatímco v Uruguayi se v jednu ráno diskotéky teprve otevírají a až od dvou hodin ráno se začíná tančit. Stejně tak vystoupení na uruguayském karnevalu začínají až v osm večer a končí kolem druhé ráno.

Uruguayci tráví mnoho času v zaměstnání, několik respondentů mělo více než jeden celý úvazek.

Ve výpovědích nově příchozích imigrantů na téma, jací jsou Uruguayci, se opakovaly odpovědi: skromný, konzervativní, stydlivý, klidný. Jedna respondentka popsala Uruguay jako nostalgickou zemi. Další respondentce se zdají být Uruguayci zprvu uzavření. „Uruguayci my přišli ze začátku dost uzavření, nepustí si tě k sobě. Jakmile tě ale př́ijmou, jsou to věrní přátelé. Když už tě mají na svém seznamu přátel, zvou tě každý týden na asado a večirky.“ (Sarah, 31 let) Jsou to podle ní dobře vychovaní lidé. Podle jiné respondentky jsou Uruguayci lidé, kteří vždy podají pomocnou ruku ,(...) i když si o nich nemyslím, že jsou nějak extra pozitivní, vždycky ti natáhnou pomocnou ruku a snaži se tě podpořit.“ (Katrin, 24 let)

Ve srovnání názorů členů a nečlenů skupiny je na základě výše zmíněných popisů osobních vlastností Uruguayců možné najít shodné charakteristiky. Konkrétně to jsou adjektiva: nostalgický a konzervativní. Vzhledem k tomu, že byla zmiňována během 
rozhovorů několikrát v různých kontextech, mohli bychom na ně nahlížet jako na stereotypní představy o Uruguaycích. V literatuře se uvádí, že slavná věta „como Uruguay no hay“ (není druhé Uruguaye), která až do dnešních dnů asociuje názor, že „tehdy bylo lépe“ pochází z období „zlatého věku“ (nebo také „tlustých krav“) před rokem 1955. ${ }^{40}$

\section{Oblíbená konverzační témata}

Jak již bylo zmíněno, respondenti věří, že uruguayský fotbal je jeden z faktorů, na jehož základě jsou rozeznáváni a uznáváni ve světě. Všichni respondenti se shodli, že fotbal je disciplína, která jim jde, na kterou se cítí být hrdí a rádi o ní diskutují.

Nedávno prŕíchozí imigranti doporučili jako vhodná konverzační témata také fotbal a dále téma uruguayské krajiny, která je dalším z atributů uruguayské hrdosti. Respondenti zmínili konkrétní místa - Cabo de Polonio, Rocha, Punta del Este.

V obou rozhovorech zazněla i politika, což je v rozporu s následující poznámkou o tomto tématu, a to v otázce společenského tabu. Dvě respondentky uvedly, že politika je téma, které se řeší pouze v rodině. Jiná informátorka sdělila, že politiku nemůže řešit ani se svými nejbližšími přáteli, protože se jejich názory neshodují a mohli by se pohádat. Jiná respondentka to prrirovnala k tématu náboženství, kdy každý má svůj názor, za kterým si pevně stojí, a svůj způsob smýšlení, který je pro něj nevyvratitelný, a zároveň odlišný postoj nepřijatelný. Takové diskuse končí podle ní vždy hádkou.

Podle několika respondentek se obvykle ve společnosti mluví o aktuálních tématech a dění. Uvedly př́klady - reportáže televizních novin, nové seriály Netflixu a módu. V období karnevalu se v Uruguayi řeší převážně jeho jednotlivá vystoupení.

\section{Neoblíbená konverzační témata}

V obou skupinových rozhovorech bylo prvním zmíněným tématem vše spojené se sexem a sexualitou. „Uruguayci jsou hodně rezervovaní a neradi mluví o čemkoli sexuálním. Možná jen s někým, komu opravdu di̊věruji. “" (Lucía, 24 let) V návaznosti na to, byla zmíněná témata homosexuality, trans genderu a potratu, avšak zde se respondenti neshodli a bezesporu záleží na otevřenosti konkrétní osoby k těmto tématům.

Téma pro Uruguayce obzvlášst' nepř́ijemné je diktatura. Stále je to poměrně nedávná minulost, která byla velmi delikátní a dodnes zraňuje. Dosud jsou ve společnosti nevyřešené

\footnotetext{
${ }^{40}$ ZOUREK, Michal. Uruguay: Stručná historie států. Praha: Libri, 2015, s. 56.
} 
př́ípady zmizelých osob, matky čekající na návrat svých dětí, lidé, kteří stále nejsou potrestáni a další nevyřešené případy.

Jiným neoblíbeným konverzačním tématem jsou penize. Respondenti vypověděli, že nesdělují, kolik vydělávají ani svým kamarádům. „Je časté že, ti někdo oznámí, že jede na dovolenou až těsně předtím, než odjede. Pro jistotu... “ (Camila, 24 let)

Někteří respondenti rozporovali, že výše zmíněná témata nejsou tak zásadními tabu.

\section{Společenská tabu}

Respondenti uvedli společenská tabu - způsob odivání, sex, promiskuita, politika, náboženství a $d r o g y$. Podle tazatelky respondenti pravděpodobně chápali otázku podobně jako $O$ jakých tématech Uruguayci neradi mluví, protože většina odpovědí se shodovala.

V minulosti podle výpovědí respondentů chodili v Uruguayi všichni oblečeni v černé, tmavě modré nebo šedivé barvě a oblečení jiných barev v zemi nebylo v obchodech $\mathrm{k}$ dispozici. Přesto, že se situace $\mathrm{v}$ posledních letech mění a mladí lidé už cítí větší svobodu nosit barevné nebo extravagantní oblečení, které již lze koupit, stále převládá velmi diskrétní a minimalistický styl odívání. Hlavně ve formálních zaměstnáních se nosí téměř pouze černá a šedivá. Jedna mladá respondentka se svěrila, že se musela dlouho odhodlávat, než si vzala legíny ve fuchsiové barvě na veřejnost. Zatím však nejsou tyto svobodomyslné tendence na ulicích př́liš znatelné a většina obyvatel se obléká do barev tlumených. Ve společnosti existuje podle respondentů ohledně oblečení mnoho předsudků, a když někdo nosí oblečení, na kterém je viditelná určitá značka, je evidentní, že pochází z bohaté rodiny a podobně. Prý je to obecně hodně kritizováno, ale dané osobě to do očí nikdo neřekne. To, že jsou Uruguayci ve stylu oblékání konzervativní, zmínili i dva nedávno příchozí imigranti.

I když je v Uruguayi marihuana legální, podle výpovědí respondentů má její oficiální užívání svá úskalí. Když je někdo zapsán v oficiálním registru uživatelů (na základě kterého si může pravidelně kupovat bylinu v lékárně) a žádá o půjčku v bance, ta na tuto skutečnost pro přiznání půjčky nahlíží jako na nežádoucí fakt. Pro většinu respondentů jsou drogy pro konverzaci s rodiči tabuizovaným tématem.

Politika je podle výpovědí Uruguayců kontroverzním tématem a své postoje a názory lidé nesdílejí veřejně. V rodinném kruhu obvykle ano, ale pro většinu respondentů to není téma, které by se řešilo mezi př́áteli. 


\section{Jazyk}

V oblasti kultury bývá vyzdvihována jedinečnost jazyka, který často hraje roli jejího nosného prvku. Svébytný jazyk však nemusí být podmínkou existence etnika, avšak možnost komunikace rozhodně podporuje pocit vzájemnosti. ${ }^{41}$

Uruguay je z jazykového hlediska velmi homogenní zemí. Španělština, která je oficiálním jazykem země, je také prvním jazykem pro více než 99 procent populace. Uruguayská španělština, stejně jako argentinská španělština, byla poněkud upravena Italy, kteří se stěhovali ve velkém počtu do obou zemí. Obecně je uruguayská španělština měkčí než kastilská a některá slova se liší od jazyka běžně používaného ve Španělsku. Gaučové ovlivnili jazyk, a to zejména slovy, která souvisejí se způsobem jejich života. Kromě španělštiny existuje řada menšinových jazyků, kterými mluví velmi malé skupiny obyvatelstva. Mezi ně patří portugalština, Portuñol, italština, němčina, ruština a Plautdeutsch. Portuñol, který mísí portugalštinu a španělštinu, je z nich nejpopulárnější. ${ }^{42}$

Uruguayský dialekt je v hlavním městě Montevideu velmi silný, a i pro španělsky mluvící návštěvníky může být z počátku náročné mu porozumět. V následujících odstavcích budou zachyceny nejmarkantnější rozdíly oproti kastilské španělštině.

Rioplatenský dialekt charakteristický lingvistickým jevem, který se vyznačuje nahrazováním osobního zájmena kastilského „tu“ (v překladu „ty“), rioplatenským „,vos“ (v překladu také „ty“). Rioplatenské „Vos“ doprovází specifické konjugace ve slovesných časech. Tento zájmenný tvar, ani jeho př́slušné časování, se v kastilské španělštině nepoužívá.

Pokud jde o užívání zájmen, je pro celý region Latinské Ameriky běžné pro vykání užívat zájmeno „ustedes“ (v překladu „oni“) namísto „vosotros“ (v překladu „vy“) ve spojení s náležitým slovesným časováním. Tvar zájmena „vosotros“ a jeho slovesné časování se v Uruguayi vůbec nepoužívá.

Dalším nepřehlédnutelným specifikem dialektu Rioplatense je odlišná výslovnost „1l““ $\mathrm{a}$, ,““, které se obecně vyslovuje jako ,j“, ale v místním dialektu jako ,ک̌‘. Zourek na konci své knihy o Uruguayi ${ }^{43}$ uvádí, že se „11“" vyslovuje jako „こ̌“, s čímž ovšem nelze souhlasit.

\footnotetext{
${ }^{41}$ TESAŘ, Filip. Etnické konflikty. Praha: Portál, 2007, s. 24.

${ }^{42}$ Languages in Uruguay [online], 2019. [cit. 2019-11-15]. Dostupné z: https://www.studycountry.com/guide/UY-language.htm

${ }^{43}$ ZOUREK, Michal. Uruguay: Stručná historie státio. Praha: Libri, 2015.
} 


\section{Pozdrav}

Rituál pozdravu patří mezi nejfrekventovanější formu společenského styku. Tento projev zastává významnou roli ve společenském životě většiny lidí. Pozdrav rozdělujeme na verbální a neverbální, přičemž se jeho způsob liší podle pravidel etikety dané společnosti. Obvykle se jedná o podání ruky, polibek, úklon, smeknutí apod. Každá kultura si vytvořila své vlastní způsoby zdravení a loučení, které se praktikují v závislosti na situaci a postavení.

Podle výpovědí dotazovaných a osobní zkušenosti výzkumnice je forma pozdravu v Uruguayi značně specifická. Součástí verbální části pozdravu je zvolání „Ahoj“ a zdvořilostní otázka „Jak to jde“ nebo „Jak se mášs“. Neverbální část je jeden polibek na pravou tváŕ, konkrétně Uruguayci přiloží tvář na tvář toho druhé a hlasitě mlasknou. Polibek si běžně dávají také muži. Obvykle se ve vyšší společnosti podává ruka bez polibku, ale podle respondentů jsou i př́pady, kdy je i ve vysoké společnosti polibek běžný. Nejlepší je podle dotazovaných počkat na impulz společensky nadřazené osoby a podle toho se zachovat. Odmítnutí polibku by mohlo být nahlíženo jako porušení dobrých mravů. Podle respondentů je důležitá i intenzita stisku ruky a hlasitost mlasknutí. Když někdo nestiskne ruku, svědčí to o jeho nezájmu. V neformální společnosti se polibek dává i při seznámení s cizí osobou. Uruguayci jej vnímají jako přirozenost, hezké gesto, které buduje vztahy a je pro ně projevem přijetí. Polibek je běžný i v nejužším rodinném kruhu jako ranní pozdrav. Zmiňovaná zdvořilostní otázka typu „Jak se mášs“ nebo „Jak to jde“ je úvodem při navazování jakýchkoli konverzací a podle respondentů má různé konotace. Někdo v jejím položení spatřuje povinnost nebo společenskou normu. „Je to slušnost. V̌̌dycky se snažíme ukázat, že se máme dobře, i když tomu tak být nemusí. Není to o tom, abychom se někomu otvírali." (Camila, 27 let) Z toho vyplývá, že jediná možná a očekávaná odpověd’ na otázku „Jak se máś“ je „Bien y vos?“" v překladu „Dobře a $V y$ ?“ a na tu už se odpoví pouze „,bien“ - „dobře“. Z rozhovorů vyplývá, že funkce této otázky není zjistit kdo a jak se má, a nikdo nechce slyšet jinou odpověd’ než „dobřre“. Sama výzkumnice se setkala s lhostejností, když na začátku svého pobytu (než toto pravidlo zjistila), odpovídala všem Uruguaycům na otázku ,jak se mášc podle skutečnosti.

Tato zdvořilostní fráze se použivá také $\mathrm{v}$ písemné korespondenci, a to často i ve formálním prostředí - např. na akademické půdě. Při písemném projevu se ovšem na tuto otázku neodpovídá.

Jeden z respondentů sdělil, že když ho někdo osloví, aniž by se otázal ,jak se máš“, vnímá to jako urážku. Jiná respondentka uvedla, že je to forma uruguayské „,nepřímosti“ 
v komunikaci, kdy opravdu není možné někoho oslovit s naléhavou prosbou o pomoc, aniž by se předtím zeptal ,jak se máte“.

\section{Uruguayská otevřenost vůči imigrantům vs. zkušenosti nově příchozích imigrantů.}

Všichni respondenti jsou v zásadě otevřeni prríchodu nových imigrantů. Někteří z nich jako důvod uvedli demografickou křivku a trend stárnoucí populace, kdy ekonomicky aktivního obyvatelstva ubývá. Dvě respondentky poznamenaly, že dnes je obecným trendem mladých vzdělaných lidí zaměřit se na kariéru a založení rodiny odložit. Jako pozitivní přínos příchodu imigrantů byla ještě zmíněna jazyková a kulturní výměna, jejich pozitivní a skromný prŕístup k životu. Někdo věří, že imigranti přicházejí do země motivováni potřebou sehnat zaměstnání, což může mít na Uruguayce pozitivní vliv. Uvědomí si konkurenci a začnou na sobě více pracovat. Jiní se obávají zaměstnavatelů, kteří zaměstnají imigranty za nižší plat, což může ničit konkurenceschopnost erudovaných adeptů. Zároveň nechtějí, aby imigranti kvůli ekonomické nouzi přijímali zaměstnání za nižší plat, než který odpovídá jejich pracovní činnosti. Někdo je otevřený proto, že by to chtěl mít sám jinde ve světě zrovna tak. Jeden respondent však zpochybňoval, že by vstup do země a přijetí v ní měli Uruguayci někde stejně tak snadné, jako je tomu pro imigranty u nich. Většina respondentů si totiž myslí, že je přijetí imigrantů v zemi rychlý proces. Jsou přesvědčeni, že imigranti si mohou hned zařídit potvrzení o trvalé rezidenci, průkaz identifikace a sehnat zaměstnání i bydlení. Jedna respondentka to rozporovala prŕběhem kamarádky, které z politických důvodů neuznali univerzitní titul, a ona nemohla sehnat zaměstnání v oboru, ve kterém je odbornicí.

Nově přríchozí imigranti potvrdili rychlé vyřízení registračního čísla, se kterým mohou žádat o zaměstnání; doplnili však, že mají zkušenost s tím, že zaměstnavatel požadoval i potvrzení o trvalé rezidenci, jehož vyřízení trvá řádově několik měsíců. Nově př́íchozí imigrantce z Kuby v Uruguayi neuznali dosažené vzdělání, a aby jí ho uznali, bylo třeba vyřídit finančně náročnou srovnávací zkoušku. Respondentce z Venezuely univerzitní titul díky členství v Mercosuru uznávají, ale také je třeba ho revalidovat, to v jejím případě nebylo nutné a práci ve svém oboru získala i bez toho. U druhých dvou imigrantů se jednalo o pracovní migraci a práci měli domluvenou předem.

Když byli respondenti tázáni, zda by se zlobili, kdyby byl ve výběrovém řízení o pracovní místo vybrán imigrant a ne oni, všichni odpověděli, že ne. Někteří doplnili, že by tomu tak mělo být za předpokladu, že byl v oboru erudovanější nebo zkušenější než oni.

V souvislosti s ,uruguayskou otevřeností““ se nedávní imigranti vyjadřovali různě. Jeden respondent sdělil, že se domníval, že bude uruguayská společnost velmi otevřená 
vzhledem k jejich otevřeným zákonům, ale spletl se. Podle něj jsou Uruguayci ve skutečnosti velmi tradiční a konzervativní, a to, i když se jedná o malichernosti. Jako příklad uvedl, že když v určitém formálním prostř̌edí řekne sprosté slovo, ostatní se přes to nedokážou přenést, přestože mimo jednání to slovo také používají. V tomto ohledu je porovnal s Argentinci, kteří jsou podle něj upřímnější a opravdovější. To, že jsou Uruguayci konzervativní, zmínily další dvě imigrantky. Jedna z nich to doplnila slovy, že jsou také introvertní a chvíli trvá, než si někoho připustí k tělu. Jakmile se však tato hranice prolomí a člověk se dostane na seznam jejich přátel, je tam už nastálo. Druhá respondentka doplnila, že od Uruguayců nejednou vyslechla vyjádření, že se jim nelíbí, že stát přijímá tolik imigrantů, a že se bojí o svou kulturu. Přitom ale jí osobně vždy všichni pomohli. Když přijela do země, všichni jí uvítali a popráli štěstí. Kdykoli potřebovala s něčím pomoci, Uruguayci doporučili někoho známého, kdo by jí mohl pomoc poskytnout. Přiznala, že jejich pomocná ruka pro ni byla v těžkých začátcích požehnáním. To, kde spatřuje uruguayskou volnost, je rodinná sféra. Zdá se jí, že v Uruguayi rodiny nedrží tolik pospolu jako v její zemi původu, stejně se vyjádřila i další imigrantka.

\section{Závěr}

Přes svoji velkou kulturní rozmanitost a multietnický původ je Uruguay vzhledem ke sdílení a praktikování stejných kulturních tradic a zvyklostí homogenní společnost. Na základě provedeného výzkumu byly zjištěny atributy uruguayské etnicity a prvky uruguayské kultury, které jsou pro tuto společnost typické a jedinečné. Respondenti se na konkrétních znacích majoritně shodovali, i když je ne všechny sami reprezentují. Co ovšem sdílí většina Uruguayců, to jsou sociokulturní zvyklosti formující uruguayskou každodennost a udávající styl života. Tyto obyčeje je vhodné znát před př́ijezdem do země nebo před zahájením obchodního styku s Uruguayci.

Charakteristický uruguayský pozdrav je jeden polibek (pravá tvář na tvár̆ za doprovodu mlasknutí), který je obvyklý i ve vyšší společnosti a zdraví se takto i muži mezi sebou. Ve velmi formální společnosti se podává ruka. Respondenti doporučují počkat na impulz společensky nadřazené osoby a podle toho se zachovat. Odmítnutí polibku by mohlo být považováno za nepřátelství. Ve formálním prostředí je přetrvávající návyk decentního stylu odívání pouze v tmavých nebo tlumených odstínech. Extravagantní styl oděvu a makeupu by podle respondentů mohla působit nedůvěryhodně. Doporučené období pro obchodování v zemi je od března do prosince. Naopak se nedoporučuje prrijíždět za obchodem 
v lednu, v době letních prázdnin, které se vztahují také na soudy a jiné složky státní správy. $\mathrm{Na}$ ty navazuje počátek karnevalu, který je krásným kulturním zážitkem, ale podle respondentů snižuje výkonnost mnoha pracovních sfér. Karneval je jedno z několika oblíbených témat pro hovor stejně jako fotbal, uruguayská příroda nebo aktuální dění. Uruguayci naopak neradi mluví o penězích, resp. výši svého výdělku, o nedávné historii diktatury, o všem sexuálním a někteří o politice. Uruguayci upozorňují na svou nedochvilnost, která nemá být vnímána jako neúcta k nikomu konkrétnímu, ale společenský rys, na který lze narazit ve všech sférách. Je podle nich důležité se před př́ijezdem připravit na dlouhé časové prodlevy a byrokratické procesy, které se objevují ve všech oblastech státní správy. Podstatnou uruguayskou charakteristikou je také jejich specifická výslovnost, ojedinělá slovní zásoba a slang nazývaný Rioplatese, který se od kastilské španělštiny značně liší.

Prvky uruguayské kultury pocházejí z různých koutů světa, stejně tak jako kořeny obyvatelů Uruguaye. Mezi hlavní prvky uruguayské kultury patř́ konzumace infuze mate, což je považováno za národní, symbolickou a společenskou tradici. Začátkem února každého roku začíná pro Uruguayce velmi oblíbená událost - karneval, který trvá přibližně měsíc. Skládá se z několika disciplín, v nichž se soutěží. Jedna z nich, kterou Uruguayci považují za své kulturní dědictví a zároveň vyjádření své kritické povahy, jsou murgas. Jedná se pěveckotanečně-divadelní vystoupení, kde murga svým zpěvem kriticky hodnotí politické, společenské a jiné důležité události, které se v zemi udály. Další disciplína karnevalu bubnové pochody candombe - se praktikuje v ulicích Montevidea během celého roku. Tato tradice, která patří na seznam kulturního dědictví UNESCO, pochází od afrických otroků, kteří ji v zemi rozšśřili a Uruguayci ji přijali za svou vlastní. V Uruguayi žije podle odhadů třikrát více krav než $\operatorname{lidí}^{44}$ a konzumace jejich masa je velmi oblíbená. Uruguayci několikrát týdně pořádají s přáteli nebo rodinnou asado - grilování, při kterém připravují různé části hovězího masa. Národní pokrm je chivito, sendvič s plátkem hovězího, dalšími typickými pokrmy milanesa, tj. obalovaný hovězí nebo kuřecí řízek, alfajor - cukrovinka připravená z oblíbeného regionálního dulce de leche, dále krémový karamel, tortas fritas - smažené placky, empanadas - plněné kapsy, pizza a noky původem z Itálie, arroz con leche - sladká mléčná rýže atd.

\footnotetext{
${ }^{44}$ Production of cattle in Uruguay from 2010 to 2019 (in 1,000 heads) [online], 2019. [cit. 2019-11-08]. Dostupné z: https://www.statista.com/statistics/955431/uruguay-cattle-production-volume/
} 
Uruguayci jsou si vědomi svého různorodého původu a jsou hrdi na to, že i když jsou, jak oni sami říkají, „směsice“, udržují si určitou homogenní kulturu. Tím se také vymezují vůči Argentincům, kteří ačkoli jsou jim v mnohém podobní, mají pestrou kulturní rozmanitost a o kulturní jednotnosti u nich v zemi nelze hovořit. Ve vztahu k Argentincům ještě Uruguayci zdůrazňují svou skromnost a kritičnost, kterou dokládá výše zmiňovaná tradice vystoupení kritických Murgas. I když mají tyto dva národy mnoho společných kulturních prvků, podobný původ a dějiny ${ }^{45}$, každý z nich uznává jiné národní hrdiny. V rámci regionu Jižní Ameriky si Uruguayci připadají jedineční svou stabilní ekonomikou, kvalitou vzdělání a moderními sociálními zákony např. o potratu, trans genderu nebo o legalizaci konopí. Uvědomují si také kvalitu svého fotbalového týmu, na který jsou velmi hrdí, a díky kterému jsou podle nich rozeznáváni a uznáváni ve světě. Je patrné, že fotbal je národní sport, který formoval národní identitu a má v uruguayské společnosti důležitou sjednocující funkci.

A až se setkáte s Uruguaycem, nezapomeňte ho políbit na tvář a zeptat se ho, jak se má a když vám nabídne své mate, nepohrdněte!

¡Uruguay nomá!

\footnotetext{
${ }^{45}$ ZOUREK, Michal. Uruguay: Stručná historie států. Praha: Libri, 2015, s. 7.
} 


\section{Seznam použitých zdrojů}

Aborto en América Latina [online], 9. 8. 2018. [cit. 2019-10-14]. Dostupné z: https://www.bbc.com/mundo/noticias-america-latina-45132307

ACHUGAR, Hugo a Gerardo CAETANO, 1992. Identidad uruguaya: mito, crisis afirmación?. Montevideo, Uruguay: Ediciones Trilce. ISBN 99-743-2041-0.

ANFITTI, Federico. Garra charrúa, sello uruguayo de origen deportivo reconocido a nivel mundial [online]. Montevideo, 2018 [cit. 2021-01-16]. Dostupné z: https://www.efe.com/efe/cono-sur/cronicas/garra-charrua-sello-uruguayo-de-origendeportivo-reconocido-a-nivel-mundial/50000803-3598294

AROCENA, Felipe a Sebastián AGUIAR, ed. Multiculturalismo en Uruguay: Ensayo y entrevistas a once comunidades culturales. Av. Agraciada 3086, Montevideo, Uruguay: Gráfica Don Bosco, 2007.

CABELLA, Wanda; PORZECANSKI, Rafael. The growth of ethnic minorities in Uruguay: Ethnic Renewal or Measurement Problems?. In: Social Statistics and Ethnic Diversity. Springer, Cham, 2015. p. 175-189.

Carnaval [online] Ministerio de Turismo del Uruguay, 2012 [cit. 2019-09-17]. Dostupné z: https://turismo.gub.uy/index.php/uruguay-es/uruguay-es-carnaval

COHEN, Anthony P. Symbolic Construction of Community. Routledge, 1985. ISBN 0-41504616-5.

Culture \& Identity of Uruguay [online], 2013. [cit. 2019-11-07]. Dostupné z: http://www.safaritheglobe.com/uruguay/culture/

DELLACASSA, E., CESIO, V., VÁZQUEZ, A., ECHEVERRY, S., SOULE, S., FERREIRA, F., HEINZEN, H. Yerba mate. Historia, uso y propiedades. Revista de la Asociación de Química y Farmacia del Uruguay, 2007, 51: 16-20.

ERIKSEN, Thomas Hylland. Antropologie multikulturních společností - Rozumět identitě. 1. vydání. Praha: Triton, 2007. 272 s. ISBN 978-80-7254-925-2.

ERIKSEN, Thomas Hylland. Etnicita a nacionalismus: antropologické perspektivy. Praha: Sociologické nakladatelství (SLON), 2012. Studijní texty (Sociologické nakladatelství). ISBN 978-80-7419-053-7.

Experience Uruguay the auténtico way [online] 2017. [cit. 2019-09-11]. Dostupné z: https://www.uruguay-autentico.com/murga

GREW, Raymond. Konstrukce národní identity. In: HROCH, Miroslav. Pohledy na národ a nacionalismus: Čitanka textů. Praha: Sociologické nakladatelství, 2003.

HIRT, Tomáš. Přehled základních tezí modernistického pojetí nacionalismu: Přehledová studie. Katedra antropologických a historických věd FF ZČU: Centrum aplikované antropologie a terénního výzkumu (CAAT), 2010.

Languages in Uruguay [online], 2019. [cit. 2019-11-15]. Dostupné z: https://www.studycountry.com/guide/UY-language.htm

Ley $N^{\circ}$ 19684: LA LEY INTEGRAL PARA PERSONAS TRANS [online], 2018. [cit. 2019-1014]. Dostupné z: https://www.impo.com.uy/bases/leyes/19684-2018

Ley $N^{\circ}$ 18.987: INTERRUPCIÓN VOLUNTARIA DEL EMBARAZO [online], 2012. [cit. 201910-14]. Dostupné z: https://parlamento.gub.uy/documentosyleyes/busquedadocumentos? $=\&$ Searchtext $=$ aborto $\&$ Chkleyes $=1$

Ley $N^{o}$ 19.172: MARIHUANA Y SUS DERIVADOS [online], 2014. [cit. 2019-10-14].

Dostupné z: https://parlamento.gub.uy/documentosyleyes/busquedadocumentos $?=\&$ Searchtext $=$ marihuana $\&$ Chkleyes $=1$ 
Los pañuelos verdes, Marcela A., El candombe de la frontera argentina-uruguaya. Anthropos: International Review of Anthropology and Linguistics [online], 2014 [cit. 2019-11-17]. Dostupné z:

https://www.researchgate.net/publication/279105795_The_candombe_of_the_argentina -uruguay_border_When_the_drums_call_to_integration_and_sing_inequality

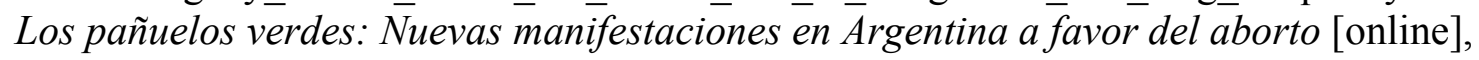
20. 2. 2019 [cit. 2019-10-14]. Dostupné z: https://www.dw.com/es/nuevasmanifestaciones-en-argentina-a-favor-del-aborto/a-47594629

LOZZA, Diego. Candombe and its socio-cultural space: a community practice [online], 2009. [cit. 2019-10-31]. Dostupné z: https://ich.unesco.org/en/RL/candombe-and-itssocio-cultural-space-a-community-practice-00182

Mate [online], 2012. Ministerio de Turismo del Uruguay [cit. 2019-09-10]. Dostupné z: https://turismo.gub.uy/index.php/en/uruguay-is/item/1382-mate

Montevideo Carnival [online], 2017 [cit. 2019-11-17]. Dostupné z: https://www.welcomeuruguay.com/carnavales/index_i.html

Murga [online], Ministerio de Turismo del Uruguay [cit. 2019-09-11]. Dostupné z: https://turismo.gub.uy/index.php/en/uruguay-is/item/1388-murga

MURRAY, Lorraine. José Mujica [online]. [cit. 2019-11-28]. Dostupné z: https://www.britannica.com/biography/Jose-Mujica

PI HUGARTE, Renzo a Daniel VIDART. El legado de los inmigrantes - 1. Montevideo: Nuestra Tierra, 1969.

Production of cattle in Uruguay from 2010 to 2019 (in 1,000 heads) [online], 2019. [cit. 2019-11-08]. Dostupné z: https://www.statista.com/statistics/955431/uruguay-cattleproduction-volume/

TESAŘ, Filip. Etnické konflikty. Praha: Portál, 2007. ISBN 978-80-7367-097-9.

TRACY, Jessica L.; ROBINS, Richard W. The psychological structure of pride: a tale of two facets. Journal of personality and social psychology, 2007, 92.3: 506.

Uruguay legalizó la producción de marihuana [online], 10. 12. 2013. [cit. 2019-10-14]. Dostupné z:

https://web.archive.org/web/20140108112840/http://www.elpais.com.uy/informacion/m arihuana-ley-senado-uruguay-parlamento.html

ZOUREK, Michal. Uruguay: Stručná historie států. Praha: Libri, 2015. ISBN 978-80-7277543-9. 


\title{
Mezietnický a občanský aspekt oslav státních svátků v Kyrgyzstánu
}

\author{
Interethnic and civil aspect of public holidays in Kyrgyzstan \\ Zhyldyz Kaarbaeva \\ Katedra historických věd Filozofické fakulty ZČU v Plzni, 2732/8, 30100 Plzeň \\ Email:kaarbaeva@mail.ru
}

DOI: https://doi.org/10.7160/KS.2021.160103

\begin{abstract}
This article presents research on interethnic relations conducted in southern Kyrgyzstan. This research was primarily concerned with the study of relations between ethnic Kyrgyz and Uzbeks in various spheres of relations between the two ethnic groups since the 1980s. The research examined the factors of improvement of the interethnic situation in the region and the conditions of ethnic and civic self-identification of various ethnic groups of southern Kyrgyzstan. The aim of the article is to show how some official state holidays can play a positive role in strengthening the unity of ethnic diversity among the citizens of Kyrgyzstan and in promoting their civic identity.
\end{abstract}

\section{Keywords}

Kyrgyz, ethnics of Kyrgyzstan, citizens of Kyrgyzstan, interethnic relations, common civic attitude, historical heritage

\section{Klíčová slova}

Kyrgyzové, etnika v Kyrgyzstánu, Kyrgyzstánci, mezietnické vztahy, společný občanský postoj, historické dědictví

\section{Úvod}

Kyrgyzstán, jako další bývalé sovětské republiky, prochází hlubokými politickými, sociálními a ekonomickými změnami. Zároveň byl zahájen proces nové etnické, občanské a náboženské identifikace obyvatelstva země. Bylo nutné vytvořit nové mechanismy fungování společnosti a státu již bez závislosti na moskevském centru. Kyrgyzstán se pokusil - jako jedna z mála zemí ve středoasijském regionu - o liberálnější cestu vývoje. Tento př́ístup státního vedení se výrazněji projevil v sociální sféře. Zároveň však docházelo ke zhoršování mezietnických 
vztahů v zemi. Otázka mezietnických vztahů a mezikonfesionálního dialogu jsou výzvy, kterým politické vedení a obyvatelstvo země musí čelit i dnes.

„Kyrgyzstánský národ“ vedle titulárního etnika tvoří představitelé více než 80 etnik ${ }^{46}$. Označení „kyrgyzstánský“ se ve větší míře začalo zdůrazňovat až po rozpadu SSSR - mělo zahrnovat všechny etnika žijící na území Kyrgyzstánu. Naproti tomu pojem „kyrgyzský“ se v tomto ohledu vztahuje jen kjedné etnické skupině, a to Kyrgyzům. V př́ípadě dějin Kyrgyzstánu se tedy nejedná o jen o dějiny Kyrgyzů, ale také o dějiny etnik, které obývají jeho území. I když o dějinách Kyrgyzstánu se spíše uvažuje v užším smyslu (jako dějiny Kyrgyzů), vývoj mezietnických vztahů a reálií formování občanské společnosti ukazují, že pro formování pocitu národní sounáležitosti, společného občanského postoje a stabilních mezietnických vztahů je třeba nahlížet na dějiny státu v jeho širším kontextu.

V Kyrgyzstánu se koná celá řada akcí, jejichž účelem je formování budoucí generace Kyrgyzstánců. Při tom se klade velký důraz na společné historické dědictví. Společné dějiny hrají roli jednoho ze základních prvků sjednocujících vědomí nastupujících generací Kyrgyzstánců.

Mezi těmito akcemi hrají zvláštní roli oslavy státních svátků. Mezi nejvýznamnější z nich patří Den Vítězství 9. května. Oslavy tohoto svátku sice nejsou součástí oficiálního státního programu usilujícího o upevnění mezietnických vztahů a formování občanské společnosti, avšak př́iklad oslav Dne Vítězství je velmi vhodný pro přiblížení významu státních svátků pro stabilizaci mezietnických vztahů a formování společného občanského postoje. $^{47}$

\footnotetext{
${ }^{46} \mathrm{~V}$ roce 2015 tvořili Kyrgyzové $72,8 \%$ podíl (5,8 mil.) z celkového počtu obyvatelstva - Naselenije. Čislennost' postojannogo naselenija Kyrgyzskoj Respubliki po otděl'nym nacional'nostjam v 2009-2018gg. Население. Численность постоянного населения Кыргызской Республики по отдельным национальностям в 2009-2018гг.) [online] Nacional'nyj statističeskij komitět Kyrgyzskoj Respubliki [cit. 9. 5. 2016]. Dostupné z: http://www.stat.kg/ru/statistics/naselenie/.

Podle statistiky ze začátku roku 2016 tvořili Kyrgyzové 73\% (6 019480 osob) z celkového počtu obyvatelstva. SULTANOV, A. (ed.) Kyrgyzstan cifralarda. Kyrgyzstan v cifrach. Biškek: Nacional'nyj statističeskij komitět Kyrgyzskoj Respubliki, 2006, s. 48. Další dostupnost: http://www.stat.kg/media/publicationarchive/b40aaf45f887-467a-8b7d-ca3943392999.pdf.

Státní statistický úřad v některých svých zdrojích uvádí jen 30 etnických skupin a v počtech zbývajících etnik tato etnika neupřesňuje. Na jiném místě statistický úrad uvádí, že Kyrgyzstán obývá více než 100 etnik Děmografičeskij ježegodnik Kyrgyzskoj Respubliki 2010-2014 gg. Biškek: Nacional'nyj statističeskij komitět Kyrgyzskoj Respubliki, 2015. Další dostupnost: http://www.stat.kg/media/publicationarchive/99205c1e-cb4d499e-b03c-fe7648456fa1.pdf.

${ }^{47}$ Jako další př́íklady svátků lze uvést konání Světových nomádských her a oslava Nooruzu (Svátek jara).
} 


\section{Metodologie}

Předkládaný př̌́spěvek je dílčím výsledkem rozsáhlejšího terénního výzkumu, který proběhl v období březen - květen 2017 ve městech Oš a Džalal-Abád v jižní části Kyrgyzské republiky. Při výzkumu bylo možné navazovat na osobní zkušenost z oslav Dne Vítězství v 90. letech 20. století, na tematickou literaturu, zdrojů z masmédií a tyto údaje jsou doplněné aktuálními rozhovory s respondenty a konzultacemi s místními odborníky. Při dotazování respondentů byla zvolena nestrukturovaná (nestandardizovaná) forma rozhovoru. Při dotazování odborníků byla použita polostrukturovaná forma rozhovoru.

\section{Den Vítězství: „můj““ svátek - „tvưj““ svátek}

Jak ukazují poslední tři roky (2015-2017), oslavy Dne Vítězství rovněž přispívají ke zmírnění mezietnické nesnášenlivosti a k prohloubení pocitu občanské sounáležitosti „Kyrgyzstáncư““ Při oslavách tohoto svátku je na prvním místě prripomínka konce 2. světové války (Velké vlastenecké války), ale připomínají se i boje sovětských vojáků během války v Afghánistánu v letech 1979-1989.

Oslavy Dne Vítězství jsou jednou z oslav, které se jeví jako součást historického dědictví Kyrgyzstánců, i když se jedná o dědictví relativně nedávné a sovětské. $O$ tom, že oslavy Dne Vítězství v Kyrgyzstánu se téměř neliší od oslav v sovětské době, svědčí nejenom sovětský formát oslav v současné době, ale rovněž vztah k těmto oslavám ze strany Kyrgyzstánců. Ačkoliv rozdíly ve vztahu k oslavám Dne Vítězství mezi Kyrgyzstánci různé etnické př́ślušnosti nejsou patrné, určité rozdíly se spíše objevují mezi vztahem k oslavám mezi starší a mladší generací Kyrgyzstánců.

Vycházíme-li z toho, že společné historické dědictví upevňuje jednotu národa, musíme si uvědomit, že se postupem času vztah mladší generace Kyrgyzstánců k oslavám 9. května může měnit. K tomu mimo jiné může dojít proto, že s každým rokem počet válečných veteránů a představitelů sovětské (starší) generace Kyrgyzstánců ubývá. Dalším důvodem může být ze strany mladší generace nezájem o sovětskou minulost, respektive o období Velké vlastenecké války, jako součástí dějin Kyrgyzstánu. To může být způsobeno nedostatečnou pozornosti vzdělávacích a výchovných institucí včetně rodiny a prostředí, v němž se děti a mládež pohybují. Nezájem o sovětskou minulost mladých lidí může také ovlivnit jejich zatím spíše více kulturní prozápadní, respektive mimoruská orientace.

Mezi veterány Velké vlastenecké války, stejně jako mezi veterány - „Afghánce“, patří občané Kyrgyzstánu (Kirgizské SSR) z různých etnik. Tato etnická rozrůzněnost ovšem vede 
k určitým sporům týkajících se podílu jednotlivých etnik a jejich účasti na dřivějších vojenských akcích.

S jedním z obdobných sporů jsem se setkala při vedení rozhovorů jak s jednotlivými respondenty, tak i odborníky. Pracovnice historického muzea v Džalal-Abádu (etnická Tatarka) uvedla, že dostává především ze strany etnických Kyrgyzů otázky ohledně počtu padlých Kyrgyzů během války. Jejich počet uvedený v seznamu padlých vojáků města je nižší než počet padlých Rusů a Uzbeků. ${ }^{48}$ Při konzultaci tohoto tématu potvrdila archiváŕka krajského archivu L. N. Halzova (etnická Ruska), že během své dlouholeté práce s archivními materiály opakovaně objevovala dokumenty, které ukazovaly, že ve válečném období nebyly ze strany Kyrgyzů výjimkou př́ípady vyhýbání se odvodům do armády. Archivářka však neupřesnila, zda se tyto př́pady týkaly Kyrgyzů z města, anebo z okolních regionů DžalalAbádské oblasti. ${ }^{49}$

Podle Pamětní knihy města Džalal-Abád (Книга памяти город Джалал-Абад) z džalal-abádského historického muzea, vyplývá, že z celkového počtu padlých obyvatel města (2 576 osob) jich prripadalo nejvíce na Kyrgyzstánce ruské etnické př́slušnosti 44,2 \%, následovanými Uzbeky - 21,9 \%, zatímco procento padlých Kyrgyzů je ve srovnání s počtem padlých Rusů a Uzbeků nižší - 14,2. Mezi padlými Džalal-Abádci najdeme rovněž Ukrajince (7,3 \%), Tatary (7 \%), Tádžiky (2,4 \%), Židy (1 \%), Bělorusy (7 lidí), Armény (6), Kazachy (5), Ázerbájdžánce (3), Baškiry (3), Turkmeny (1), Dungany (1), Bulhary (1), Mordvince (1), Poláky (1) a Němce (1). V seznamu je rovněž uvedeno, že dalších 21 osob je nezvěstných.

Dohledat $\mathrm{v}$ archivu statistické údaje městského a venkovského obyvatelstva ve válečném období ze 40 . let 20 století týkající se města Džalal-Abád podle etnického klíče ovšem není možné - celostátní sčítání proběhlo v roce 1926, 1939 a v poválečném období až v roce 1959. Proto bylo nutné vycházet $\mathrm{z}$ obecných statistických údajů Džalal-Abádského okruhu pro rok 1926 a 1939. Podle těchto údajů základ předválečného městského obyvatelstva netvořili Kyrgyzové, ale především Rusové a Uzbeci, čemuž odpovídá i vyšší počet padlých Rusů a Uzbeků.

Statistické údaje z let 1959, 1970 a 1979 ukazují, že zatímco ruské a uzbecké etnikum se soustřed'ovalo v městech, př́islušníci kyrgyzského etnika tvořili absolutní většinu obyvatel

\footnotetext{
${ }^{48}$ Rozhovor z 3. 4.2017.

${ }^{49}$ Rozhovor z 15. 4. 2017.
} 
venkova (62,1, 65,9 a 67,7 \% Kyrgyzů oproti 4,3, 2,6 a 1,5 \% Rusů a 23,5, 25,2 a 25,6 \% Uzbeků) $)^{50}$.

Tabulka 1. Podíl městského obyvatelstva v Ošské oblasti podle jednotlivých etnik (1959-1979)

\begin{tabular}{|l||l|l|l|}
\hline $\begin{array}{l}\text { Ošská oblast - podíl } \\
\text { městského obyvatelstva }\end{array}$ & 1959 & 1970 & 1979 \\
\hline \hline Kyrgyzové & $11,3 \%$ & $16,0 \%$ & $23,1 \%$ \\
\hline Rusové & $34,5 \%$ & $32,4 \%$ & $26,8 \%$ \\
\hline Uzbeci & $26,5 \%$ & $29,9 \%$ & $31,6 \%$ \\
\hline
\end{tabular}

Při porovnání těchto statistických údajů ze stejného období, které poskytuje současný státní statistický úřad je patrné, že v Džalal-Abádské oblasti žije výrazně více obyvatel ve městech (ve srovnání s Ošskou oblastí). ${ }^{51}$

Tabulka 2. Podíl městského a venkovského obyvatelstva v Ošské a Džalal-Abádské oblasti (1970, 2009)

\begin{tabular}{|l|l|l|l|l|}
\hline \multirow{2}{*}{} & \multicolumn{2}{|l|}{ Džalal-Abádská oblast } & \multicolumn{2}{l|}{ Ošská oblast } \\
\cline { 2 - 5 } & $\begin{array}{l}\text { městské } \\
\text { obyvatelstvo }\end{array}$ & $\begin{array}{l}\text { venkovské } \\
\text { obyvatelstvo }\end{array}$ & $\begin{array}{l}\text { městské } \\
\text { obyvatelstvo }\end{array}$ & $\begin{array}{l}\text { venkovské } \\
\text { obyvatelstvo }\end{array}$ \\
\hline 1970 & $30,6 \%$ & $69,4 \%$ & $9,7 \%$ & $90,3 \%$ \\
\hline 2009 & $22,6 \%$ & $77,4 \%$ & $8,0 \%$ & $92,0 \%$ \\
\hline
\end{tabular}

Podle jiných zdrojů vydaných státním statistickým úřadem vyplývá, že se podíl Kyrgyzů na městském a venkovském obyvatelstvu Džalal-Abádské oblasti postupně zvyšoval, až se jejich podíl na městském a venkovském obyvatelstvu oblasti zhruba vyrovnal - 72,6 a 71,6 \%. V Ošské oblasti podíl Kyrgyzů na městském obyvatelstvu zůstal na rozdíl od ukazatelů v Džalal-Abádské oblasti stejným. I v roce 2009, kdy proběhlo poslední sčítání lidu, podíl Kyrgyzů na městském obyvatelstvu oblasti činil výrazně méně ve srovnání s Uzbeky - 17,4 \% oproti 79,4 \% podílu Uzbeků. ${ }^{52}$

Avšak vezmeme-li podíl Kyrgyzů a Uzbeků na obyvatelstvu města Oš, nikoliv celé oblasti, nenajdeme žádné statistické údaje až do roku 1989. Údaje z roku 2009 však ukazují, že se podíl př́ílušníků obou etnik na obyvatelstvu Oše v roce 2009 zhruba srovnal - 41,3 \% Kyrgyzů oproti 48,3 \% podílu Uzbeků. ${ }^{53}$

Jinými slovy, ve všech uvedených zdrojích, ač místy odlišnými ukazateli, se uvádí, že podíl př́slušníků kyrgyzského etnika na městském obyvatelstvu jižního Kyrgyzstánu byl

\footnotetext{
${ }^{50}$ V roce 1959 došlo ke sloučení Džalal-Abadské oblasti s Ošskou. Charaktěristika Ošskoj oblasti. [online] MČS KR [cit. 22. 7. 2017] Dostupné z: http://www.mes.kg/ru/about/subordinate/oshskoi-obl/harakteristiki-oshobl/.

${ }^{51}$ Těrritorija i naselenije. [online] Nacional'nyj statističeskij komitět Kyrgyzskoj Respubliki. [cit. 22. 7. 2017] Dostupné z: http://www.stat.kg/media/files/d5a59588-1ad7-4c9e-952d-451f4da124cb.pdf. S. 5.

${ }^{52}$ Naselenije po nacional'nosti i jazyku. (Население по национальности и языку.) [online] Nacional'nyj statističeskij komitět Kyrgyzskoj Respubliki. [cit. 23. 7. 2017]

Dostupné z: http://www.stat.kg/media/files/9cd9d7ee-78f0-413e-885d-80f914049ebf.pdf. S. 3-12.

${ }^{53}$ Tamtéž, s. 3-12.
} 
od vzniku kyrgyzské státnosti nižší ve srovnání s etniky, která v té době představovaly (Rusy) a dodnes představují (Uzbeky) významné minority země. Situace se začala měnit od 80 . let, respektive už koncem 70. let 20. století. Dnes z celkového počtu populace Kyrgyzstánu tvoří Kyrgyzové 60,9 městského obyvatelstva. ${ }^{54}$

Současná odborná literatura $\mathrm{s}$ historicko-demografickou tematikou ve válečném období je omezena, respektive je málo zpř́stupněna. V knize Kyrgyzstan: perspektivy pljuralizma (Кыргызстан: перспективы плюрализма) od autorky E. Maratové ${ }^{55}$ se uvádí, že podle celosvazového sčítání lidu z roku 1926 se z celkového počtu obyvatelstva Kirgizské autonomní oblasti, které sotva dosahovalo milionu, ke kyrgyzskému etniku přihlásilo $67 \%$ obyvatel a k uzbeckému a ruskému po $11 \%$. Avšak kolektivizace a industrializace v období 30.-50. let 20. století vedla k výraznému růstu podílu ruského etnika, což způsobilo změnu ve statusu kyrgyzského etnika jako titulárního na minoritní.

\section{Den Vítězství: „nášs“ svátek}

Zde se podrobněji zaměřím na vystoupení „Nesmrtelného pluku“ jako významné součásti v rámci oslav Dne Vítězství. Do akce spojené s vystoupením „Nesmrtelného pluku“ se Kyrgyzstán zapojil v roce 2012, první pochod pluku se v republice uskutečnil o rok později. ${ }^{56}$ Jejím cílem není jen uctívání památky předků - vojáků, pracovníků týlu a nevinných obětí ale rovněž omezit snahy mocenských struktur v upravování historického materiálu a zachovat původnost oficiální historie. ${ }^{57}$ Cíle „Nesmrtelného pluku“ jsou tedy do určité míry ideologické. I proto je ale možné vidět, že každý rok 9. května oslavy Dne Vítězství a zvlášt’ akce „Nesmrtelný pluk“ alespoň dočasně sjednocují lid Kyrgyzstánu v jeden národ.

Obdobně „Nesmrtelný pluk“ působí i v Ruské federaci, kde původně vznikl jako občanská iniciativa. Ostatně v zakládající listině Nesmrtelného pluku se prŕmo uvádí, že

\footnotetext{
${ }^{54}$ Tamtéž, s. 3.

${ }^{55}$ MARAT, Erika. Kyrgyzstan: perspektivy pljuralizma. (Кыргызстан: перспективы плюрализма.) Global Centre for Pluralism, 2015.

${ }^{56}$ K akcii "Bessmertnyj polk" v etom godu prisojedinitsja Naryn. [online] Sputnik [cit. 30. 5. 2017] Dostupné z: https://www.ru.sputnik.kg/society/20170503/1033199641/k-bessmertnomu-polku-v-ehtom-goduprisoedinitsya-naryn.html Bessmertnyj polk. Letopis' (Бессмертный полк. Летопись.) [online] Oficial'nyj sajt dviženija „Bessmertnyj polk“ [cit. 31. 5. 2017] Dostupné z: http://www.moypolk.ru/letopis-polka

${ }^{57}$ Nesmrtelný pluk v Česku: důstojná odpovéd' na zkreslování historie. [online] Aliance národních sil [cit. 30.5. 2017] Dostupné z: https:/www.aliancens.cz/single-post/2017/04/26/Pochod-Nesmrteln\%C3\%BD-pluk-Praha852017.
} 
„alespoň“ jednou ročně občané Ruské federace bez ohledu na jejich politickou, náboženskou a etnickou př́slušnost tvoří jeden „Pluk“ ${ }^{58}$

Každoročně v Kyrgyzstánu probíhá celá řada akcí věnované Dni Vítězství, avšak jen málokterá vyvolala mezi Kyrgyzstánci velký ohlas a jejich dobrovolní zapojení do organizace a realizace aktivit jako je právě „Nesmrtelný pluk“.

Organizace oslav ke Dni Vítězství byla spíše doménou státu, proto i podoba jejich oslav byla oficiální - vojenské přehlídky, masová divadelní představení, sportovní závody, povinná účast státních institucí apod. Organizace a průběh „Nesmrtelného pluku“ rovněž nepředstavovaly výjimku. V Kyrgyzstánu, na rozdíl od Ruské federace, kde daná akce vznikla bez nařízení „ze shora“, byl „Nesmrtelný pluk“ již od začátku výsledkem aktivní spoluúčasti vládních struktur. Ostatně realizace obdobných akcí se v Kyrgyzstánu jen stěží obejde bez koordinace s místními státními orgány. Iniciátorem zapojení země do tohoto dnes už mezinárodního hnutí byl pracovník oddělení pro sociální a kulturní vývoj magistrátu města Oš K. Tašibajev. Před konáním vystoupení Nesmrtelného pluku v Oši v roce 2013 byl Tašibajev jedním z organizátorů obdobné akce s názvem „Věčně živí, stále ve službě“, která se konala v Oši v roce 2012. Pochod Nesmrtelného pluku v Biškeku v roce 2014 a 2015 byl zorganizován představiteli městské samosprávy. Nicméně Nesmrtelný pluk poskytnul prostor pro podobně smýšlející občany a jejich uvědomění jako celku.

Kromě masových akcí mohou při sjednocování do značné míry inspirovat i akce jednotlivých občanů. Např́iklad obyvatelé vesnice Korumdu Issyk-Kulské oblasti (severní Kyrgyzstán) Taalajbek Borombajev (etnický Kyrgyz) a Rašit Gizatulin (etnický Tatar) z vesnice Šekaftar v Džalal-Abádské oblasti (jižní Kyrgyzstán) kromě publikování pamětí o předcích a dalších obyvatelích vesnice, kteří odešli na frontu Velké vlastenecké války, postavili a zrekonstruoval pomníky padlým vojákům ve svých vesnicích z vlastních finančních prostředků. Borombajev získal prostředky z prodeje krávy, zatímco Gizatulin si za tímto účelem vzal bankovní půjčku. Rovněž z vlastních prostředků zorganizovali slavnostní odhalení pomníků a pohoštění návštěvníků včetně představitelů místních státních orgánů. Počínání obou mužů se těšilo výrazné podpoře ze strany místní veřejnosti. Gizatulin zastává názor, že podobné „,národni““ akce upevňují vztahy mezi etniky, a proto společně s dalšími obyvateli vesnice zorganizoval pochod Nesmrtelného pluku, který uskutečnil ve Šekaftaru o

\footnotetext{
${ }^{58}$ Ustav Polka. [online] Oficial'nyj sajt dviženija „Bessmertnyj polk“ [cit. 31. 5. 2017] Dostupné z: http://www.static.moypolk.ru/ustav-polka.
} 
rok dříve než v administrativním centru oblasti Džalal-Abádu. Díky své činnosti se oba aktivisté spřátelili.

Tyto prŕíklady jsou ukázkami života určitých Kyrgyzstánců, jejich přemýšlení a vnímání okolí nezkomplikované politickými, finančními, kulturními či jinými hesly. Jak dokládají respondenti, i další Kyrgyzstánci, přes obtížné politické, sociální a ekonomické podmínky, nestaví mezietnické rozdíly na pořad dne. Jsou to př́klady, kdy Kyrgyzstánci začínají projevovat vlastní iniciativy, které přes omezený význam a jednoduchý charakter mají důležitost $\mathrm{v}$ mnohonárodnostním soužití. Z tohoto hlediska je při studiu etnické problematiky v Kyrgyzstánu nutné zjistit, za jakých okolností se vztahy mezi etniky začínají komplikovat.

Dnes je téma Velké vlastenecké války zatím jedním z mála historických témat, které by u Kyrgyzstánců mohly vyvolat pocit občanské sounáležitosti na celostátní úrovni. Některé příběhy dokonce svědčí o tom, že téma Velké vlastenecké války dokáže vhodně posloužit $i$ pro překonání konfesionálních rozdílů. V roce 2015 se ve vesnici Beš-Kungej Čujské oblasti (severní Kyrgyzstán) uskutečnilo slavnostní odhalení opraveného pomníku válečním letcům I. Tarančijevu (Kirgizská SSR) a A. Tkačevu (Smolenská oblast, RSFSR). Při této př́ležitosti byl pomník požehnán knězem pravoslavné církve a modlitbu pronesl i imám.

Oslavy společných svátků jako je Den Vítězství - na rozdíl od oslav Nooruzu (Svátek jara) nebo Světových nomádských her - ukazují, jak společné historické „,výdobytky“ minulých generací mohou zmobilizovat soucit občanské a národní solidarity mezi představiteli současné generace. Ke dnešnímu dni jsem nezaznamenala svátky a oslavy, které by Kyrgyzstánce rozdělovaly. Samožrejmě, že příslušníci různých etnik v Kyrgyzstánu slaví mimo státní svátky i další, které jsou typické pro jejich etnikum. To však Kyrgyzstánce nerozděluje. Kromě toho se slaví náboženské svátky, které rovněž přispívají ke sjednocování společnosti (například muslimské svátky jako Ramadan, Ajit, Arapa vytváří mezi Kyrgyzy a Uzbeky a dalšími muslimy země pocit sounáležitosti na základě společného náboženství). Mohli bychom spíše uvažovat ne tak o spojujícím či rozdělujícím potenciálu jednotlivých svátků a oslav, jako o míře jejích významu pro určitá etnika. Tak např́íklad oslavy Dne nezávislosti Kyrgyzstánu 31. 8. nebo Nového roku neprobíhají tak slavnostně, jako náboženské svátky. Zatímco někteří věřící Kyrgyzové vedle náboženských svátků mohou oslavovat Den nezávislosti republiky nebo další sekulární svátky, většina Uzbeků spíše dává přednost oslavám svátkům náboženským. 
Vytvářet pocit občanské solidarity a vlastenectví na základě společných dějin je jedním zklíčových aspektů poklidného občanského soužití mezi příslušníky etnicky rozmanité kyrgyzstánské společnosti. V daném případě kořeny „společných dějin“ v širším smyslu dosahují k sovětské minulosti země. Proto dodnes oslavy probíhají v sovětském formátu a v zemi obecně jsou patrné stopy sovětské epochy.

Odkaz Kyrgyzstánu na svou sovětskou minulost neznamená „,zpátečnickou“ či „Zaostalou“ podobu jeho současného vývoje. Ostatně vyškrtnout $\mathrm{z}$ historické minulosti země téměř 70 let sovětské epochy se nejeví možným ani ze žádného důvodu potřebným. Jde o to, že kyrgyzská státnost byla „dopřána“ kyrgyzskému národu až v rámci Sovětského svazu. Proto k prozápadní přeorientaci Kyrgyzstánu v brzké době dojde jen stěží. Nesmíme též zapomenout na ještě přetrvávající vrstvu kyrgyzstánské společnosti, která se označuje jako sovětská generace a která má široký vliv mezi obyvatelstvem země dodnes.

At' se tedy jedná o jakoukoliv státní a společenskou sféru, nelze se obejít bez zmiňování sovětské minulosti. Stejně tak i kořeny problematiky kyrgyzsko-uzbeckých vztahů v současném Kyrgyzstánu jsou odvozeny ze sovětské minulosti země. To však neznamená nemožnost jejího vyřešení v budoucnu. Pouhé zjišt’ování, že určitý problém, spor, konflikt, je pozůstatkem sovětské, respektive carsko-ruské koloniální politiky, řešení aktuálních problémů Kyrgyzstánu neprospívá. Stejně jako jeho opakovatelné zmiňování v různých psaných a nepsaných zdrojích nemění nic na tom, že s někdejšími sovětskými spornými otázkami se budou muset vyrovnat postsovětské generace.

I kdyby historický vývoj Kyrgyzstánu byl jiným, obdobné nevyřešené problémy rovněž mohla po sobě zanechat kterákoliv jiná država. Je třeba si uvědomit, že při formulaci stanovisek k jednotlivým aspektům problémů a zejména při jejich řešení nestačí jenom znát historické souvislosti, ale třeba také zapojit umění vyrovnat se s minulostí, rovněž jako odhodlanost a schopnost racionálního řešení historických sporů ve světle aktuálního dění.

Aktuální dění Kyrgyzstánu nám zatím ukazuje, že se v zemi usiluje o formování národa, přesněji o posilování nejenom etnické (rozuměj titulárního etnika), ale i občanské složky společnosti. ${ }^{59}$ Problémem je, že to nejsou procesy stabilizující. Průběh těchto (ale i dalších) procesů ukazuje, že od doby získání nezávislosti se Kyrgyzstán nachází ve stavu, kde není jisté a jasné, jakým způsobem se dotvoří.

\footnotetext{
${ }^{59}$ STRAPÁČOVÁ, Michaela; HLOUŠEK, Vít. Budování státu a národa v podmínkách postkonfliktní rekonstrukce Kosova. Středoevropské politické studie. 2014, 16 (2-3), 160-187.
} 


\section{Druhé Světové nomádské hry, 2016}

V roce 2016 došlo pro Kyrgyzstán k významné události, která měla symbolizovat jeho návrat k historickým kulturním pramenům. V období 3. 9. - 8. 9. 2016 se konaly Druhé Světové nomádské hry, jejichž slavnostního zahájení se sice kromě kyrgyzského prezidenta A. Atambaeva nezúčastnila žádná další hlava státu, ale význam her byl demonstrován tisíci jejich účastníků, hosty ze zahraničí a množstvím samotných Kyrgyzstánců. Ostatně právě absence hlav států přispěla méně formálnímu průběhu her, které se staly „národní“ slavnostní událostí. ${ }^{60}$

V souvislosti s Druhými Světovými nomádskými hrami (DSNH) se také bylo možné často setkat s používáním prefixu - etno (etnosport, etnoměsto, etnomóda, etnokultura). Zachování tradičních sportovních her pro budoucí generace a jejich přibližení zahraničnímu publiku považovali organizátoři DSNH za způsob obnovy kulturního dědictví země. ${ }^{61}$ DSNH se však nestaly pouhou sportovní událostí, která by vedla k obnově kulturního dědictví, ale také událostí, která poskytla prostor i pro mezikulturní dialog.

Ačkoliv se DSNH staly mezinárodní událostí, jejich význam pro Kyrgyzstánce samotné je důležitější. Organizace a průběh her sjednotily Kyrgyzstánce, at' jsou to organizátoři, účastníci nebo publikum, bez ohledu na jejích etnickou př́islušnost, což umožnilo konání her na té úrovni, na které v roce 2016 byly pořádány.

Tato velkolepá akce byla zorganizována s důrazem na kyrgyzskou etnickou kulturu. Ovšem snahy Kyrgyzů, rovněž jako i dalších etnik, o zachování své tradiční kultury by neměly představovat bezprostřední hrozbu jiným etnikům a jejich vlastním kulturám v Kyrgyzské republice.

O tom, že kyrgyzská etnická kultura ve vztahu k jiným etnikům v Kyrgyzstánu nemusí být vnímána jako převládající (vyjma jazykovou sféru), svědčí současná situace v republice na jihu Kyrgyzstánu je uzbecký kulturní vliv převládajícím. Některé prvky uzbecké kultury

\footnotetext{
${ }^{60}$ Her se účastnily sportovci dle různých zdrojů od 40 do 60 zemí světa, včetně Itálie, Spojených států amerických, Iránu, Polska, Mad'arska a Botswany. RADOVANOVIČ, D., Zapomeñte na olympiádu, v Kyrgyzstánu pořádali Světové nomádské hry. Jak vypadá hra s bezhlavou kozou? In: Český rozhlas, [online], [cit. 2017-04-22]. Dostupné z: http:/www.rozhlas.cz/plus/svet/zprava/zapomente-na-olympiadu-vkyrgyzstanu-poradali-svetove-nomadske-hry-jak-vypada-hra-s-bezhlavou-kozou--1648738; Всемирнье игры кочевников. Что знают о Всемирных играх кочевников жители США, Швеции Греции, Ирана. In: Боорсок, [online], [cit. 2017-04-22]. Dostupné z:http://www.boorsok.ru/tag/vsemirnye-igry-kochevnikov/; Всемирные игры кочевников - 2016 в Киргизии. In: РИА Новости, [online], [cit. 2017-04-20]. Dostupné z: https://www.ria.ru/photolents/20160905/1476064391.html; Итоги II Всемирных игр кочевников (список). In: КирТаг, [online], [cit. 2017-04-20]. Dostupné z: http:/www.kyrtag.kg/society/itogi-vtorykh-vsemirnykh-igrkochevnikov-spisok.

${ }^{61}$ Всемирные игры кочевников в Кыргызстане. Видео. In: Asiarussia.ru, [online], [cit. 2017-05-01]. Dostupné z: http://www.asiarussia.ru/news/13466/.
} 
jsou však dnes zaměňovány, respektive kombinovány hlavně kvưli zesilujícím reislamizačním tendencím s „arabskými“ kulturními prvky. V sovětské době byl citelnější vliv sovětské, respektive ruské kultury a dnes jsme svědky toho, jak kyrgyzská kultura dostala větší prostor pro svou obnovu a další vývoj.

O tom, že kyrgyzská kultura nedominuje nad uzbeckou, potvrzují současné módní trendy mezi Uzbeky, kteří často preferují řadu prvků arabského původu. V Kyrgyzstánu již téměř nepotkáte Uzbeky $\mathrm{v}$ uzbeckém tradičním oblečení, respektive v oblecích toho stylu, který byl rozšířen mezi Uzbeky v sovětském a na začátku postsovětského období. Uzbecké tradiční oblečení se dnes stálo spíše symbolickou záležitostí slavnostních událostí jako je např́iklad svatba, ale i v tomto př́ípadě částečně. Jestli tyto změny jsou vyvolány jen dočasnou „módou“ anebo se zakotví mezi Uzbeky a dalšími etniky, vyznávajících islám, na delší dobu, lze odpovědět jenom v závislosti na další vývoj reislamizačních tendencí v zemi.

„Arabský“ styl oblékání včetně nošení hidžábu vysvětlovaly respondentky - uzbecké ženy - tím, že uzbecká kultura (v daném případě se jednalo o vnější vzhled žen dle uzbecké národní tradice oblékání) není „zapomenutá“, „,vytlačená“, či že by na ni dobrovolně rezignovaly. Přesto je uzbecký styl oblečení dodržován pouze $\mathrm{v}$ úzkém rodinném a přátelském kruhu. Podle nich národní uzbecké oblečení nezahaluje jejich části těla tak, jak je vyžadováno islámskými pravidly. Například v tradičním uzbeckém oblečení se ne vždy dá skrýt tvar postavy, šíje, vlasy, a pokud je třeba i obličej.

Některé z respondentek pak dodaly, že právě kvůli tomu, že uzbecké (stejně tak i kyrgyzské či tatarské) kulturní prvky v současném muslimském oblečení žen „mizí z veřejnosti“, a také vzhledem k tomu, že ze strany je tak těžko rozpoznatelná jejich etnická př́slušnost, se rozhodly pro dodání k jejich muslimskému oblečení tradiční pro jejich etnickou kulturu prvky. Na otázku, proč si respondenti zvolili hidžáb, niqáb, al-amiru, zejména starší ženy khimar, burku a dokonce svůj místní způsob zahalování místo toho historicky tradičního pro středoasijské ženy ve Ferganské nížině parandži, jsem žádnou odpověd' nedostala. ${ }^{62}$

\footnotetext{
${ }^{62}$ Terénní výzkum z období leden - duben 2017.
} 


\section{Seznam použitých zdrojů}

Bessmertnyj polk. Letopis' (Бессмертный полк. Летопись.) [online] Oficial'nyj sajt dviženija „Bessmertnyj polk“ [cit. 31. 5. 2017] Dostupné z: http://www.moypolk.ru/letopis-polka

Bessmertnyj polk. Letopis' (Бессмертный полк. Летопись.) [online] Oficial'nyj sajt dviženija „Bessmertnyj polk“ [cit. 31. 5. 2017] Dostupné z: http://www.moypolk.ru/letopis-polka

Děmografičeskij ježegodnik Kyrgyzskoj Respubliki 2010-2014 gg. Biškek: Nacional'nyj statističeskij komitět Kyrgyzskoj Respubliki, 2015. Další dostupnost: http://www.stat.kg/media/publicationarchive/99205c1e-cb4d-499e-b03cfe7648456fa1.pdf

Charaktěristika Ošskoj oblasti. [online] MČS KR [cit. 22. 7. 2017] Dostupné z: http://www.mes.kg/ru/about/subordinate/oshskoi-obl/harakteristiki-osh-obl/.

Itogi II Vsemirnych igr kočevnikov (spisok). (Итоги II Всемирных игр кочевников (список).) [online] KirTag [cit. 20. 4. 2017]. Dostupné

z: http://www.kyrtag.kg/society/itogi-vtorykh-vsemirnykh-igr-kochevnikov-spisok.

K akcii "Bessmertnyj polk" v etom godu prisojedinitsja Naryn. [online] Sputnik [cit. 30. 5. 2017] Dostupné z: https://www.ru.sputnik.kg/society/20170503/1033199641/kbessmertnomu-polku-v-ehtom-godu-prisoedinitsya-naryn.html

Krasivaja oděžda i tancy-jarmarka s učastijem posol'stv prochodit v Biškeke. (Красивая одежда и танцы - ярмарка с участием посольств проходит в Бишкеке.) [online] Sputnik, 21. 3. 2017 [cit. 15. 5. 2020]. Dostupné

z: https://www.ru.sputnik.kg/culture/20170321/1032393278/diplomaticheskayayarmarka-v-bishkeke.html.

MARAT, Erika. Kyrgyzstan: perspektivy pljuralizma. (Кыргызстан: перспективы плюрализма.) Global Centre for Pluralism, 2015.

Naselenije po nacional'nosti i jazyku. (Население по национальности и языку.) [online] Nacional'nyj statističeskij komitět Kyrgyzskoj Respubliki. [cit. 23. 7. 2017] Dostupné z: http://www.stat.kg/media/files/9cd9d7ee-78f0-413e-885d-80f914049ebf.pdf. S. 3-12

Naselenije. Čislennost' postojannogo naselenija Kyrgyzskoj Respubliki po otděl'nym nacional'nostjam v 2009-2018gg. (Население. Численность постоянного населения Кыргызской Республики по отдельным национальностям в 2009-2018гг.) [online] Nacional'nyj statističeskij komitět Kyrgyzskoj Respubliki [cit. 9. 5. 2016]. Dostupné z: http://www.stat.kg/ru/statistics/naselenie/.

Nesmrtelný pluk v Česku: důstojná odpověd’ na zkreslování historie. [online] Aliance národních sil [cit. 30. 5. 2017] Dostupné z: https://www.aliancens.cz/singlepost/2017/04/26/Pochod-Nesmrteln\%C3\%BD-pluk-Praha-852017.

NOORUZ - 2017. (HOOPY3 - 2017). [online] Gos. Agentstvo po dělam mestnogo samoupravlenija i mežetničeskich otnošenij [cit. 15. 5. 2017]. Dostupné z: http://www.gamsumo.gov.kg/ru/news/full/318.html.

RADOVANOVIČ, D. Zapomeñte na olympiádu, v Kyrgyzstánu pořádali Světové nomádské hry. Jak vypadá hra s bezhlavou kozou? [online] Český rozhlas [cit. 22. 4. 2017]. Dostupné z: http://www.rozhlas.cz/plus/svet/_zprava/zapomente-na-olympiadu-vkyrgyzstanu-poradali-svetove-nomadske-hry-jak-vypada-hra-s-bezhlavou-kozou-1648738.

STRAPÁČOVÁ, Michaela; HLOUŠEK, Vít. Budování státu a národa v podmínkách postkonfliktní rekonstrukce Kosova. Středoevropské politické studie. 2014, 16 (2-3), 160-187. DOI: https://www.doi.org/10.5817/CEPSR.2014.23.160. 
SULTANOV, A. (ed.) Kyrgyzstan cifralarda. Kyrgyzstan v cifrach. Biškek: Nacional'nyj statističeskij komitět Kyrgyzskoj Respubliki, 2006, s. 48. Další dostupnost z: http://www.stat.kg/media/publicationarchive/b40aaf45-f887-467a-8b7dca3943392999.pdf

Těrritorija i naselenije. [online] Nacional'nyj statističeskij komitět Kyrgyzskoj Respubliki. [cit. 22. 7. 2017] Dostupné z: http://www.stat.kg/media/files/d5a59588-1ad7-4c9e952d-451f4da124cb.pdf.

Vsemirnye igry kočevnikov - 2016 v Kirgizii (Всемирные игры кочевников - 2016 в Киргизии). [online] RIA Novosti, 5. 9. 2016 [cit. 20. 4. 2020]. Dostupné z: https://ria.ru/20160905/1476064391.html.

Vsemirnye igry kočevnikov v Kyrgyzstaně. (Всемирные игры кочевников в Кыргызстане). [online] Asiarussia.ru, 5. 9. 2016 [cit. 1. 5. 2020]. Dostupné z: http://www.asiarussia.ru/news/13466/.

Vsemirnye igry kočevnikov. Čto znajut o Vsemirnych igrach kočevnikov žitěli SŠA, Švecii Grecii, Irana. (Что знают о Всемирных играх кочевников жители США, Швеции Греции, Ирана). [online] Boorsok, [cit. 22. 4. 2017]. Dostupné z: http://www.boorsok.ru/tag/vsemirnye-igry-kochevnikov/. 


\title{
Formovanie kultúrnej a etnickej identity Maoriov prostredníctvom príslušnosti ku gangu
}

\section{Forming the cultural and ethnic identity of Maoris through gang membership}

\author{
Lucia Bistárová \\ Filozofická fakulta UCM v Trnave, Námestie J. Herdu 2, 91701 Trnava \\ Email: lucybistar@yahoo.com
}

DOI: https://doi.org/10.7160/KS.2021.160104

\begin{abstract}
Though often called a "heaven on Earth" New Zealand suffers from a serious problem with gangs. Ethnic gangs have dominated the New Zealand gang scene since the 70s when many Maoris left traditional rural areas and migrated in search of work to the cities but ended up in poverty because of lack of skills and poorly-paid jobs. Maori urbanization and the dual pressures of acculturation and discrimination resulted in a breakdown of the traditional Maori social structures and alienated many from their culture. Maoris who have been unable to maintain their ethnic and cultural identity through their genealogical ties and involvement in Maori culture attempt to find it elsewhere. For many of those that have lost contact with their cultural and ethnic links gangs have replaced families and community and provides individuals with a sense of belonging and safety. The aim of this article is to demonstrate the role of gangs in Maori ethnic and cultural identity development. This paper demonstrates the impact of gang environment on individual identity development and provides evidence that cultural engagement initiatives can enhance Maori identities, which in turn could increase psychological and socio-economic wellbeing.
\end{abstract}

\section{Keywords}

Ethnicity, cultural identity, Maori, gang, New Zealand, acculturation, tradition

\section{Klíčová slova}

Etnicita, kultúrna identita, Maori, gang, Nový Zéland, akulturácia, tradícia 


\section{Úvod}

„, Gangy začali zabezpečovat' to, čo nedokázala rodina, škola a iné zariadenia sociálnych služieb - rozvoj mládeže, ich noriem správania sa a budovanie priestoru, kde nachádzajú priatel'stvo, podporu a ochranu. “l

Ciel'om tohto príspevku je preukázat' význam gangov pri formovaní maorijskej etnickej a kultúrnej identity a zodpovedat' tri základné otázky - aký je dôvod vzniku a existencie etnických gangov v priestore Nového Zélandu, ako sa v priebehu posledných 20 rokov tieto gangy zmenili a aké sú motivácie mladých Maoriov sa k nim aj v súčasnosti pridávat?

Na Novom Zélande v súčasnosti existuje viacero druhov pouličných či motorkárskych gangov, z ktorých niektoré sa formovali za účelom poskytnutia ochrany a spolupatričnosti svojim členom, iné vznikali ako kriminálne či protispoločenské organizácie, zamerané na ilegálne aktivity. V krajine sa začali objavovat' v období po skončení druhej svetovej vojny, no najväčší rozmach prišiel $v$ 70. rokoch 20. storočia, kedy vel'ká čast' maorijského obyvatel'stva migrovala z rurálnych oblastí do miest s vidinou nájdenia lepšej práce. Nízka, alebo žiadna kvalifikácia Maoriov, ktorí do miest prichádzali, mala za následok, že si nedokázali nájst' dobre platenú prácu. Vystavení spoločenskej a kultúrnej diskriminácii, tak mnoho mladých Maoriov hladalo útočisko a podporu práve v gangoch. ${ }^{2}$

Dnes Maoriovia tvoria viac ako tri štvrtiny celkového počtu príslušníkov gangov $\mathrm{v}$ krajine. ${ }^{3}$ Motivácie príslušnosti ku gangom sa líšia od jedného gangstra k druhému. Niektorí vstúpili do gangu s vidinou zbohatnutia z nelegálnej činnosti. Iných tam priviedli strach, problémy s drogami či alkoholom. Naprieč najväčšími gangmi Nového Zélandu, ktorými sú Mongrel Mob, Black Power či Head Huners, však rezonujú príbehy o hl'adaní rodiny, komunity a pocitu spolupatričnosti, ktorú v spoločnosti nenachádzajú. Mnohí považujú príslušnost' ku gangu za demonštráciu toho, že sú Maoriovia. Gang pre nich predstavuje formu protestu voči zbytkom koloniálnej politiky a akulturačných tlakov, ktoré ich pripravili o pôvodnú kultúru a možnost' identifikovat' sa ako Maori.

\footnotetext{
${ }^{1}$ VIGIL, James, D. Barrio Gangs: Street life and identity in Southern California. Austin: University of Texas Press, 1988, s. 168.

${ }^{2}$ KINNEAR, Karen L. Gangs: A Reference Handbook. Santa Barbara: ABC-CLIO, LLC, 2009, s.109.

${ }^{3}$ NEWBOLD, Greg a TAONUI, Rawiri. Gangs - Gangs and Crime; Te Ara - the Encyclopedia of New Zealand [online]. 2011 [cit. 2021-01-27]. Dostupné z: https://teara.govt.nz/en/gangs/page-4.
} 


\section{Výskum v špecifickom regióne}

Nový Zéland je vel’mi špecifická krajina, pri zmienení ktorej si snád’ ani nedokážeme predstavit' všetky rastliny a zvieratá, ktoré na tomto geograficky izolovanom súostroví môžeme nájst'. Čo je však pre predstavu ešte t'ažšie, je to, že by mala byt' iná aj kultúra obyvatel’ov tejto krajiny, ktorú poznáme ako súčast' nám tak dobre známeho, „západného sveta““4. Nový Zéland je domovom rozličných l’udí a rozličných kultúr. ${ }^{5}$ Aj pri prevahe obyvatel'ov európskeho pôvodu, môže skrývat' výskum v tamojšom prostredí mnoho metodologických, ale i spoločenských nástrah, ktoré sa môžu stat' problémom pri zbere a neskoršom vyhodnocovaní výskumného materiálu.

Ako však takýto terénny výskum v prostredí Nového Zélandu vlastne prebieha? Vo všeobecnosti treba mysliet' na pravidlo, platné nielen pri skúmaní v priestore Nového Zélandu, že výskumník prichádza do terénu pripravený. Štúdium literatúry a rôznych iných zdrojov pomôže výskumníkovi aspoň čiastočne pochopit' kultúru, ktorú sa vydáva skúmat' a môže tak zmiernit' kultúrny šok, ktorý s vel'kou pravdepodobnost'ou čaká už za bránami letiska vybranej destinácie. Spoznávanie danej kultúry do najmenších podrobností je údelom a cestou etnológa, na ktorú sa vydal výberom tejto vednej disciplíny. ${ }^{6}$ Neznalost' miestnych sociálnych noriem môže spôsobit' problémy v teréne a častokrát napáchat' nenapravitel'né škody, ktoré môžu výskumníkovi nadobro zavriet' dvere u respondenta, alebo v horšom prípade v celej komunite.

Už v počiatočnej fáze prípravy sa etnograf môže dopustit’ prvých chýb. Kultúrny suicentrizmus, alebo etnocentrizmus a stereotypy o určitých geografických priestoroch a ich obyvatel'och môžu predstavovat' základnú chybu pri výskume. Konštruovanie obrazu o mimoeurópskych kultúrach a balíček predstáv a očakávaní, ktoré si so sebou na výskum

\footnotetext{
${ }^{4} \mathrm{~V}$ tomto prípade pod pojmom ,západný svet“ máme na mysli krajiny EÚ, USA, Kanady, Austrálie a Nového Zélandu.

${ }^{5}$ Nový Zéland je v súčasnosti označovaný ako multikultúrna krajina s bikultúrnym „dedičstvom“, ktoré vychádza zo znenia tzv. Zmluvy z Waitangi (podpísaná 6. 2. 1840), uzatvorenej medzi maorojskými vodcami a predstavitel'mi britskej koruny, ktorá právne ukotvila odovzdanie Nového Zélandu pod správu britskej koruny a zároveň stanovila rovnoprávne postavenie maorijského obyvatel'stva. Zmluvu z Waitangi považujú mnohí z radov Maoriov aj európskych Novozéland'anov za najvýznamnejší národný symbol a zakladajúcu listinu krajiny. Dokument bol v deň podpisu podpísaný viac ako 40 maorijskými náčelníkmi a zástupcami britskej koruny v zátoke Waitangi, na severe Severného ostrova v Zátoke ostrovov (Bay of Islands). Následne boli naprieč ostrovmi rozoslané kópie podpísanej zmluvy, ktoré dodatočne podpísalo d’alších približne 500 náčelníkov.

KOLLÁROVÁ, L’ubica. Identita a jazyk dvoch hlavných zložiek novozélandskej spoločnosti: Maori a Pakeha. Praha: Tribun EU, 2013, s.16.

${ }^{6}$ Podl’a Franza Boasa je „,...potrebné každú kultúru skúmat’ v jej jedinečnosti a jej jedinečnom geografickom a klimatickom prostredí, ktoré nadväzuje na jedinečný historický vývin." Viac v: KANOVSKÝ, Martin. Kultúrna a sociálna antropológia: Osobnosti a teórie. Bratislava: Chronos, 2004, s.42.
} 
nesieme, nám totiž podmieňuje to, čo $\mathrm{v}$ teréne uvidíme a neuvidíme, teda $\mathrm{v}$ konečnom dôsledku determinuje a skresl'uje naše poznanie týchto kultúr. ${ }^{7}$

Od obdobia prvých kontaktov maorijského obyvatel'stva s európskymi osadníkmi nastala vzt'ahová situácia, ktorej následky môžeme pozorovat' do súčasnosti. Od začiatku kolonizácie krajiny totiž čelili pôvodní obyvatelia Nového Zélandu spoločenskému, ale aj legislatívnemu a ústavnému útlaku zo strany európskych prist'ahovalcov. ${ }^{8} \mathrm{~S}$ koncom represívnej koloniálnej éry však prichádzajú globalizačné procesy, ktoré pôvodnému obyvatel'stvu ponúkajú tak nevýhody, ako aj príležitosti. Maoriovia ako jednotlivci, ale i ako kolektív reagujú rôzne na tieto zmeny a procesy, ktoré ovplyvňujú ich sebaurčenie a ciele. ${ }^{9}$ Posledných približne 200 rokov $^{10}$ prichádza ku stretom a konfrontáciám dvoch svetov, ktoré sa vzájomne prelínajú a ovplyvňujú, a vytvárajú tak špecifické prostredie Nového Zélandu.

Koloniálna politika, asimilačné tlaky, nútené adopcie a čiastočná segregácia maorijského obyvatel'stva vyústila do rôznych vyhrotených situácií a predovšetkým má za následok vel'kú nedôveru a skepticizmus, ba prípadnú nevraživost' voči európskemu obyvatel'stvu - Pakehom ${ }^{11}$ zo strany Maoriov. Predovšetkým u starších l'udí a v chudobných vrstvách rurálnej maorijskej spoločnosti sa zakorenil stereotyp, že biely človek (Európan) je nepriatel', alebo ten, kto môže za ich biedu či nepriazeň osudu. Napriek tomu, že sa nám môže tento prístup zdat' nanajvýš úsmevný, alebo „nefér““, treba mat’ na pamäti realitu maorijskej

\footnotetext{
${ }^{7}$ KARÁSEK, Matej. L'udskost’ ako elementárna metóda (nie len v Indii). Terénny výskum v špecifickom prostredi. Univerzita sv. Cyrila a Metoda v Trnave, 2015, s. 8.

${ }^{8}$ Podpísaním Zmluvy z Waitangi začali na ostrove platit' britské zákony. Každý narodený na území britského impéria získaval na Novom Zélande rovnaké zákonné práva, ako občania Vel'kej Británie. Maoriovia získali všetky práva a výsady Britov podl’a článku 3 Zmluvy z Waitangi, a túto pozíciu posilňoval aj zákon o právach domorodých obyvatel'ov z roku 1865. Avšak následné úpravy zákonov znevýhodňovali pôvodné obyvatel'stvo vo viacerých smeroch. Narastajúci počet anglicky hovoriacich obyvatel'ov spôsobil, že maorijčina viac nebola považovaná za lukratívny jazyk a angličtina predstavovala vidinu lepšej budúcnosti. Angličtina bola povýšená na úradný a vyučovací jazyk a dodatok zákonu o školách z roku 1879 zakazoval používanie maorijčiny v školách. Zákon ,, The Tohunga Suppression Act “ z roku 1907, zas vyslovene zakazuje Maoriom praktizovat’ svoju kultúru tým, že zakazuje akúkol’vek vzdelávaciu alebo duchovnú činnost’ Tohunga (kňaz, spirituálny vodca a odborník na tradičnú maorijskú kultúru). V praxi to znamenalo, že Maoriovia mohli byt' sankcionovaní za to, že akoukol'vek formou praktizovali svoju pôvodnú kultúru. Viac na: New Zealand Acts As Enacted: Native Rights Act 1865 (29 Victoriae 1865 No 11) [online]. 2020 [cit. 2021-01-26]. Dostupné z: http://www.nzlii.org/nz/legis/hist_act/nra186529v1865n11281/. KOLLÁROVÁ, L’ubica. Status a revitalizácia jazyka novozélandských Maoriov: Jazyk je poklad [online]. 2003 [cit. 2021-01-26]. Dostupné z: is.cuni.cz > webapps > zzp > download.

${ }^{9}$ DURIE, Mason. Te Mana, Te Kawanatanga - The politics od Maori Self-Determination. Auckland: Oxford University Press New Zealand, 1998, s. 4-13.

${ }^{10}$ Počítam od podpísania Zmluvy z Waitangi z roku 1840.

${ }^{11}$ Pakeha je oficiálnym a v bežnej reči zaužívaným termín označujúci Novozéland'anov európskeho pôvodu. Jedným z možných doslovných prekladov tohto maorijského slova je „bledý“. Od roku 2000 je v anglickom jazyku za pravopisne správnu považovaná forma písania vel'kého „P“ na začiatku, nakol'ko tento termín označuje etnický pôvod, nie rasu. V texte je, na základe týchto pravidiel, používaná forma písania Pakeha s vel'kým „P“. Viac na: GRAY, Claire, Nabila JABER a Jim ANGLEM. Pakeha identity and whiteness: What does it mean to be white? Sites: New Series 10(2) [online]. 2013 [cit. 2021-01-26]. Dostupné z: https://sites.otago.ac.nz/Sites/article/viewFile/223/255.
} 
spoločnosti v minulosti a v súčasnosti. V spoločnosti rezonujúci rasizmus a údajný nezáujem vlády a príslušných orgánov o problémové rodiny či skupiny na okraji spoločnosti, ktoré sú tvorené prevažne jedincami maorijského pôvodu, vyústila do atmosféry nedôvery a strachu voči autoritám, alebo vo všeobecnosti voči belochom.

Vel'ká čast' maorijskej populácie aj v súčasnosti žije vo vidieckych lokalitách za mestami, čo môže v priestore Nového Zélandu pokojne znamenat' aj odl'ahlé oblasti, medzi sebou vzdialené desiatky kilometrov. Odl’ahlé rurálne oblasti sú zvyčajne osídlené farmármi a malými skupinami Maoriov. Budovanie vzt'ahov a dôvery je vel'mi zdíhavá a komplexná záležitost', spoločnost' a pomoc tamojších priatel'ov, alebo lokálnych autorít je pri skúmaní izolovaných skupín v špecifickom prostredí nevyhnutnost'ou. Hlúšek uvádza, že ,, situácia na vidieku je pre výskumníka, a ešte k tomu cudzinca, náročná a krátkodobý výskum je možný iba $v$ tých lokalitách, v ktorých už bol predtým uskutočnený výskum dlhodobý a bádatel’ v nich má vytvorené dostatočné zázemie v podobe známych a priatelov. " 12

Jednoduché situácie bádatel' nenachádza ani v mestách. Odstup zo strany respondentov, opísaný na predchádzajúcich riadkoch sa v urbánnom prostredí nezmenšuje, práve naopak, častokrát môže pôsobit' ešte vyhrotenejšie, vzhl'adom na sociálne rozdiely, ktoré sú v meste badatel'nejšie. Nerovnosti a znevýhodnenie pôvodných obyvatel'ov voči majoritnej spoločnosti vychádzajú vo vel'kej miere z koloniálnej histórie Nového Zélandu. Môžu mat' za následok obmedzený prístup ku kvalitnému vzdelaniu a pracovným príležitostiam, nízke príjmy a vyššiu mieru chudoby, nízky štandard bývania, vyššie riziko zdravotných problémov, vysokú mieru psychických porúch a relatívne vysokú mieru kriminality a marginalizáciu tejto minority. ${ }^{13}$

Získavanie dôvery informátorov, ktorí boli ochotní a schopní poskytnút' relevantné dáta, predstavovalo nepochybne najzložitejšiu a časovo náročnú čast' celého procesu získavania informácií v teréne. Informátormi boli Maoriovia, ktorí sú aktívnymi členmi gangu, bývalými členmi, alebo sú v blízkom spojení s niekým, kto v gangu je. Výskum prebiehal vo viacerých oblastiach Severného ostrova, predovšetkým v mestskej štvrti Otara na juhu Aucklandu, v mestečku Opotiky, Tolaga Bay a Tauranga, na prelome rokov 2018 a 2019. Ani predchádzajúci pobyt, štúdium literatúry, dokumentov a filmov ma nedokázal

\footnotetext{
${ }^{12}$ HLÚŠEK, Radoslav. Špecifiká výskumu v domorodých komunítách v Mexiku. Terénny výskum v špecifickom prostredí. Univerzita sv. Cyrila a Metoda v Trnave, 2015, s. 23.

${ }^{13}$ Obraz postavenia Maoriov v spoločnosti Nového Zélandu je vypracovaný na základe oficiálnych údajov Novozélandského štatistického úradu (Statistics of New Zealand) a Agentúry pre spracovanie výsledkov sčítania l'udu (Stats NZ-Cenzus 2018. Viac na: Cenzus. Stats New Zealand [online]. 2020 [cit. 2021-01-26]. Dostupné z: https://www.stats.govt.nz/topics/census.
} 
pripravit' na niektoré situácie, ktoré sa s odstupom času zdajú prosté, no v momentoch ked' sa diali boli šokujúce. Tento špecifický kultúrny šok však bolo potrebné prekonat' snád' rýchlejšie, ako si ho vôbec uvedomit'. Akokol'vek absurdne, nesprávne či nespravodlivo mohla situácia pôsobit', v komunitách týchto marginalizovaných skupín išlo o každodennú realitu, ktorá sa stala pre nich normálnou. Práve bezprostredné vyrovnanie sa so šokujúcimi situáciami bolo klúčovým pri budovaní si (nevyhnutného) vzt'ahu s informátormi. Nadviazanie takéhoto vzt’ahu a akéhosi spojenia medzi etnografom a informátorom predstavuje budovanie pocitu dôvery, ktorá počas rozhovorov zabezpečuje vol'ný tok informácií. ${ }^{14}$ Jedným zo spôsobov, ako bolo tento vzt’ah možné dosiahnut', bol ambivalentný prístup k nezákonnému či protispoločenskému správaniu, ktorého svedkom som bola. ${ }^{15}$

Miera zainteresovanosti v každodennom živote niektorých informátorov presiahla akékol'vek predstavy, ktoré som pred príchodom do lokality mala. Napriek tomu, že sa stala najdôležitejším pohonom toku informácií od respondentov, prinášala, vzhl'adom na citlivú povahu výskumu, rôzne etické dilemy. Rozhovory často zasahovali do citlivých spoločenských tém, akými sú domáce násilie, sexualita, zneužívanie, protispoločenské správanie. Stalo sa, že počas rozhovorov „vyplávali na povrch“ také informácie, ktoré boli v rozpore s mojím osobným presvedčením, no napriek tomu nebolo možné ich komentovat', alebo do tejto reality akokol'vek zasahovat' a to v rámci zachovania bezpečnosti informátorov, ale aj mojej vlastnej.

Ako už bolo uvedené, získanie dôvery respondentov je nevyhnutnou súčast'ou výskumu, o to zložitejšou však je, ak ide o komunity, kde skúmané osoby nie sú ochotné odpovedat' v súlade so skutočnost'ou, nakol'ko majú obavy a predsudky, že ich výpoved' môže byt' použitá proti ním. Výskumník pre nich totiž často predstavuje rovnakú hrozbu, ako sociálni pracovníci, ktorí im odoberajú ich deti, alebo napr. exekútori, ktorí im berú to málo, čo im ešte ostáva. Je základnou povinnost'ou výskumníka všetky citlivé informácie zabezpečit' proti zneužitiu, ${ }^{16}$ a preto $\mathrm{v}$ tomto príspevku neuvádzam mená respondentov z výskumu v komunitách, ktoré obklopovali niektorý z gangov.

Všeobecná podozrievavost' a nedôvera členov voči „outsiderom“ komplikovala nie len nadväzovanie kontaktov, ale aj pozorovanie, pri ktorom si výskumník ponecháva od aktérov

\footnotetext{
${ }^{14}$ SPRADLEY, James. The Ethnographic Interview. New York: Holt, Rineheart, and Winston, 1979, s. 78.

${ }^{15}$ Považujem za dôležité uviezt', že počas môjho pôsobenia v komunite, som sa nestala svedkom žiadneho závažného trestného činu zo strany informátorov s ktorými som bola v kontakte. Avšak s výskumom skupín, ktoré prejavujú kriminálne, alebo protispoločenské správanie, prichádza aj určité riziko, ktoré výskumník pre získanie materiálu musí podstúpit'.

${ }^{16}$ REICHEL, Jiř́i. Kapitoly metodologie sociálních výzkumů. Praha: Grada, 2009, s. 175-178.
} 
odstup. Prítomnost' cudzinky - ženy vyvolávala rôzne reakcie, ktoré neboli pri výskume nápomocné, práve naopak, častokrát situácie komplikovali. Moja prítomnost', často vo výlučne mužskom kolektíve, pôsobila príliš rušivo a z týchto dôvodov som uprednostňovala rozhovory s jednotlivcami, pred rozhovormi skupinovými.

\section{Literatúra a médiá ako zdroj informácií}

Pre získanie kvalitných a relevantných informácií k skúmanej téme bolo potrebné štúdium vel'kého množstva historických prameňov a archívnych súborov rôznych médií. Patrili k nim články z novín, prepisy politických diskusií, správy, výskumy a výsledky štatistík vlády a polície, prípadne rôzne osobné dokumenty pochádzajúce od informátorov. Významným zdrojom informácií boli archívy novozélandského denníka New Zealand Herald (NZ Herald), z ktorých hojný obsah je dostupný online na stránkach denníka ${ }^{17}$ a národnej knižnice ${ }^{18}$. Články a úvodníky týkajúce sa gangov boli dôležité pri mapovaní histórie gangov v krajine a časovom rozvrhu hlavných udalostí, ktoré sa dostali do médií. NZ Herald pochopitel'ne nebol jediným mediálnym zdrojom pri získavaní informácií o konkrétnych miestnych udalostiach, no poskytol prehl'ad najdôležitejších tém týkajúcich sa gangov, ktoré rezonovali v spoločnosti od konca 60 . rokov.

Tematike gangu a kriminálnych skupín sa v súčasnosti venuje vel'ké množstvo literatúry, nakol'ko sa tento fenomén objavuje v mestách naprieč celým svetom. Tento príspevok sa zaoberá gangmi v prostredí Nového Zélandu, ale terénny materiál a získané informácie boli pri vyhodnocovaní konfrontované literatúrou zaoberajúcou sa predovšetkým gangmi v prostredí Spojených Štátov Amerických, so širokou škálu prehl'adu súčasných etnických gangov, ale aj minulosti. Z klúčových je nutné spomenút' dielo akademika priekopníka, ktorý sa ako prvý zaoberal detailným štúdiom gangov, príčinám a následkom ich vzniku. Frederic Thrasher svojím dielom The Gang: A Study of 1,313 Gangs in Chicago z roku 1927 poskytol prvý komplexný popis mládežníckych gangov a ich organizácie a položil tak základy vedeckého záujmu o gangy 20. storočia. ${ }^{19}$ Diela Joan Moore (1978, 1991) venujúce sa barrio gangom (latinoamerické gangy ako napr. Mara Salvatrucha, 18th Street gang atd'.) predstavujú vel'ký zdroj inšpirácie v kontextoch významu etnickej identity

\footnotetext{
${ }^{17}$ New Zealand Herald: Searched topic: Gangs [online]. Archív. [cit. 2021-04-22]. Dostupné z: https://www.nzherald.co.nz/search/gangs/

${ }^{18}$ National Library: Topic: NZ Herald [online]. Archív. [cit. 2021-04-22]. Dostupné z: https://natlib.govt.nz/items?text=NZ+herald

19 THRASHER, Frederic M. The Gang: A Study of 1,313 Gangs in Chicago. Chicago: University of Chicago Press, 1927.
} 
pri členstve v gangu. Z novozélandských autorov spomeniem Grega Newbolda a Jarroda Gilberta, ktorí sa venujú histórii a kriminalite gangov v krajine a ich diela predstavujú zdroj informácií, pochádzajúcich z ich vlastných dlhoročných výskumov priamo $\mathrm{v}$ komunitách gangov. $^{20}$ Tieto diela poskytujú nie len chronologický prehl'ad dôležitých míl'nikov súvisiacich s vývojom gangov v prostredí Nového Zélandu, ale aj osobné skúsenosti s príslušníkmi a komunitami, ktoré ich obklopujú, čím pomohli zodpovedat' rôzne otázky či pochybnosti, ktoré počas vyhodnocovania vlastného materiálu vznikli.

Ďalšou ústrednou témou tohto príspevku je problematika formovania etnickej a kultúrnej identity súčasných Maoriov. ${ }^{21}$ Podl'a Kollárovej (2013), Durieho (1998) či Metgeovej (1964) bola maorijská identita tradične určovaná príslušnost'ou k súboru rozšírenej rodiny (whanau) a kmeňu (iwi). Tieto sociálne skupiny boli a vistej miere stále sú, zodpovedné za medzigeneračné odovzdanie kmeňových a sub-kmeňových vedomostí, ktoré sú piliermi kultúrnej identity Maoriov. ${ }^{22}$ Vel'mi dôležitými aspektmi maorijskej identity sú aj genealogické línie whakapapa, zmysel príslušnosti kurčitému priestoru spájanému s predkom, ovládanie jazyka, kmeňovej histórie a mytológie. ${ }^{23}$ Výchova jednotlivca, komunita a priestor, $\mathrm{v}$ ktorom vyrastá, prípadná obmedzená interakcia $\mathrm{s}$ kmeňovými oblast'ami môžu ale viest' k tomu, že jedinec tieto vedomosti nezíska. To malo za následok, že mnohí Maoriovia v mestách, d’aleko odvzhl'adom na absenciu genealogických a kultúrnych informácii, neboli schopní sa identifikovat' ako Maori.

Identita je sociálny konštrukt, ktorý jednotlivec bežne používa na opis toho, za koho sa považuje. Je to dynamický koncept, ktorý sa neustále mení, vyvíja a prispôsobuje, podl’a toho, čo človek zažíva a v akých situáciách sa nachádza. ${ }^{24}$ Etnická identita je ovplyvnená sociálnym kontextom a vonkajšími faktormi a je opísaná ako trvalý aspekt seba samého, ktorý zahŕn̆a zmysel pre príslušnost' k etnickej skupine a všetky postoje a pocity s týmto členstvom

\footnotetext{
${ }^{20}$ GILBERT, Jarrod. Patched: The History of Gangs in New Zealand, 2013.; GILBERT, Jarrod a NEWBOLD, Greg. Youth Gangs, 2006.; NEWBOLD, Greg. Crime in New Zealand, 2000 a iné.

${ }^{21}$ Nakol'ko je gang fenomén týkajúci sa prevažne miest a tento príspevok sa sústred'uje na formovanie identity prostredníctvom príslušnosti ku týmto skupinám, venujem pozornost’ predovšetkým procesom formovania morijskej identity v mestskom prostredí.

${ }^{22}$ DURIE, Mason. Te Mana, Te Kawanatanga - The politics od Maori Self-Determination, Auckland: Oxford University Press New Zealand, 1998, s. 58.

${ }^{23}$ METGE, Joan. A new Maori migration: Rural and urban relations in northern New Zealand. London: The Athlone Press, 1964.

${ }^{24}$ BOURDIEU, Pierre. Teorie jednání. In: Teorie Jednání [online]. 1998, s. 16-24. [cit. 2021-04-22]. Dostupné z: http://www.sds.cz/docs/prectete/eknihy/pb_tj.htm.
} 
spojené. $^{25}$ Podl’a Bartha (1969) etnicitou označujeme súbor teórií, ktoré sú založené na tvrdení, že l'udia môžu byt' klasifikovaní v rámci ohraničených skupín, na základe spoločných fyzických a behaviorálnych podobností, ktoré „,...sú pravdepodobne určené pôvodom a sociálnym pozadím... “. ${ }^{26}$ Etnicita je podl’a neho vecou sociálnej organizácie, kedy je nepodstatné, ak sú jednotlivé skupiny rozdielne, pokial' si dokážu nájst' aspoň nejaký spoločný prvok, a ten si nejakým spôsobom bránit'. V tomto prípade, teda nie je podstatné, či sa osoba kmeňovo identifikuje s nejakým predkom a konkrétnym priestorom $\mathrm{v}$ rámci tradičného rurálneho priestoru, alebo si svoju etnickú identitu vytvára v mestskom priestore, bez konkrétneho genealogického pozadia. Spájajú ju s etnikom totiž určité prvky, ako napr. jazyk a prejavy tradičnej kultúry (nasledovanie tradičných zvykov a rituálov pri narodení, smrti, prejav prostredníctvom tetovania, umenie a i.). Táto koncepcia predstavuje základ pri hl'adaní súvislostí medzi príslušnost'ou ku gangu a tvorením identity Maoriov, ktoré sú predstavené na nasledujúcich riadkoch.

\section{Akulturácia Maoriov a jej následky}

Pôvodní obyvatelia Nového Zélandu - Maoriovia, sú považovaní za etnickú skupinu vážne poznamenanú kolonizáciou. ${ }^{27}$ Po podpísaní Zmluvy z Waitangi boli vystavení procesu európskej kolonizácie, ktorý viedol k postupnému odcudzeniu Maoriov od ich tradičnej kultúry a prijatiu kultúry európskej. Na tieto procesy straty vlastnej kultúry a jej čiastočné či úplné nahradenie cudzou (prinesenou) kultúrou možno nahliadat’ prostredníctvom konceptu akulturácie a nútenej asimilácie domorodého obyvatel'stva Nového Zélandu. ${ }^{28}$

V súčasnosti sociálni vedci definujú akulturáciu ako proces psychologickej a sociokultúrnej adaptácie, ktorý je výsledkom nepretržitého kontaktu kultúrne rozdielnych skupín s následkom zmien pôvodných kultúrnych vzorcov u jednej alebo oboch skupín. ${ }^{29}$ Tieto zmeny by podl'a Redfielda, Lintona a Herskovitsa, nemali byt' zamieňané s procesom asimilácie, nakol'ko tá je len jednou z fáz samotnej akulturácie. Takýto úzky kontakt dvoch

\footnotetext{
${ }^{25}$ PHINNEY, Jean S. Understanding ethnic diversity: The role of Ethnic identity. American Behavioral Scientist 40(2) [online]. 1996, s. 143-152. [cit. 2021-04-22]. Dostupné z: https://journals.sagepub.com/doi/10.1177/0002764296040002005.

${ }^{26}$ BARTH, Frederik. Ethnic Groups and Boundaries: The Social Organization of Culture Difference. Boston: Little, Brown and Company, 1969, s. 13.

${ }^{27}$ FERGUSSON, David M. Ethnicity and Interpersonal Violence in a New Zealand Birth Cohort. Violent Crime: Assessing Race and Ethnic Differences. Cambridge: Cambridge University Press, 2003, s. 138-153.

${ }^{28}$ Tamtiež, s. 139.

${ }^{29}$ REDFIELD, Robert, LINTON, Ralph a HERSKOVITS, Melville J. Memorandum for the Study of Acculturation. American Anthropologist, 38(1). 1936. DOI: https://doi.org/10.1525/aa.1936.38.1.02a00330. s. 150 .
} 
odlišných skupín (kultúr) má vplyv na obe skupiny, no intenzívnejšie je zvyčajne ovplyvnená nedominantná skupina a jej členovia. ${ }^{30}$ Zmeny spôsobené procesmi akulturácie môžu mat' vplyv na rôzne aspekty života ovplyvňovaných jedincov, ako napríklad správanie, postoje, hodnoty, alebo kultúrna identita. ${ }^{31}$

Průchova definicia akulturácie tiež poukazuje na fakt preberania určitých prvkov z cudzej kultúry, ale zároveň aj ich odmietanie, vylučovanie alebo pretváranie, počas ktorého môže dochádzat' k udržiavaniu vlastnej kultúry, alebo aspoň jej čiastkových aspektov. ${ }^{32}$ V tomto procese tak prichádza k akémusi „importovaniu“ tradičných kultúrnych zvyklostí, ktoré v novovzniknutom sociokultúrnom priestore môžu úplne, alebo čiastočne zmenit' svoj pôvodný význam.

V priestore maorijského Nového Zélandu sa stretávame pomerne často s úkonmi a zvykmi, ktoré nazývame tradičnými, v zmysle Hobsbawm-Rangerovho konceptu vymyslených (resp. znovuobjavených) tradícií (invented tradition). Pod pojmom vymyslené tradície máme na mysli tie, ktoré sú akýmisi prijatými pravidlami a snažia sa vštepovat' určité hodnoty a normy správania sa. Tieto „tradície“ čiastočne, alebo úplne nadväzujú na ich pôvodnú historickú podstatu. Maoriovia ich obnovujú, resp. znovuobjavujú po období akulturačného tlaku, počas ktorého mohli byt' určité fragmenty tradícií a kultúry stratené, a teda môžu byt' čiastočne modifikované podl’a ich súčasných potrieb. ${ }^{33}$ Cez túto koncepčnú optiku je možné sledovat' a vyhodnocovat' viaceré aspekty života súčasných Maoriov, ktorými je aj formovanie ich kultúrnej a etnickej identity v priestore súčasného Nového Zélandu.

Chalmersová vo svojom výskume naznačuje, že členovia etnických skupín môžu čelit' stresu a marginalizácii, ak sa neintegrujú do dominantnej kultúry, avšak na druhej strane, pri „úspešnej“ integrácii jednotlivcov z minoritných skupín hrozí, že sa odcudzia svojej vlastnej skupine, čo môže viezt' k strate ich kultúrnej identity. ${ }^{34}$ Ďalej jednotlivci, ktorí sa nedokážu integrovat', ale zároveň ani nedokážu udržat' kontakt so svojou kultúru, sú ponechaní na

\footnotetext{
${ }^{30}$ JELEŇOVÁ, Iveta a SÁPOSOVÁ, Zlatica. Jazyk, Interetnické vzt’ahy a použivanie mad'arského jazyka v Košiciach. Košice: Centrum spoločenských a psychologických vied SAV, 2018, s. 21.

${ }^{31}$ Tamtiež, s. 22.

${ }^{32}$ PRŮCHA, Jan. Interkulturni psychologie. Praha: Portál, 2010, s. 32.

${ }^{33}$ HOBSBAWM, Eric a RANGER, Terence O. The Invention of Tradition. Cambridge: Cambridge University Press, 1903, s. 3.

${ }^{34}$ CHALMERS, Tess. Exploring Māori Identity Behind Closed Doors: An investigation of Māori cultural identity and offender change within Waikeria Prison's Maori Focus Unit, Te Aa Marama. Albany: Massey University, 2014, s. 24.
} 
pomedzí týchto dvoch svetov bez kultúry, nepatriac ani do jednej skupiny, ako napríklad mestskí Maoriovia. ${ }^{35}$

Existuje teda relatívny konsenzus, že kolonizácia a akulturácia mali za následok stratu aspektov maorijskej kultúry s negatívnymi dôsledkami, ako sú sociálne nevýhodnejšia pozícia, nižšia miera vzdelanosti, vyššia kriminalita. ${ }^{36}$ Tieto pretrvávajúce väzby medzi etnickým pôvodom a individuálnym alebo kolektívnym blahobytom poskytujú možné odpovede voblasti vysokej miery medzil'udského násilia a príslušnosti ku gangom u novozélandských Maoriov.

\section{„Byt' Maori“6 - koncept formovania identity}

Ciel'om tohto príspevku je poukázat' na proces formovania etnickej a kultúrnej

identity novozélandských Maoriov prostredníctvom príslušnosti ku gangu. $\mathrm{Na}$ to je však potrebné vysvetlit' koncept chápania kultúrnej identity v prostredí Nového Zélandu, ktorá sa prelína s definíciou etnickej identity. Kultúrnou identitou sa nazýva spoločenská identifikácia toho, kto sme, založená na jazyku, viere, spoločných znalostiach mýtov a hrdinov. Určuje spoločné postoje, pocity ale i hodnotové orientácie jednotlivca v rámci skupiny a zároveň ovplyvňuje jeho osobnú identitu. ${ }^{37}$ Identita etnická využíva určitý aspekt kultúry či predstavu na odlíšenie sa od ostatných. ${ }^{38}$ Identita Maoriov pred príchodom Európanov bola zakorenená v príbuzenskej sieti založenej na genealógii (whakapapa) a vzt’ahujúcej sa na určitú lokalitu. Hlavným identifikačným kritériom bola príslušnost' ku kmeňu (iwi), v rámci neho k rodu

\footnotetext{
${ }^{35}$ Urbanizačné procesy v krajine, po druhej svetovej vojne, spôsobili migračný tok celých skupín, rodín, ale aj jednotlivcov z vidieckeho prostredia do mestských centier. Presun do miest predstavoval vidinu kvalitnejšieho života, v podobe lepšie platenej práce, vzdelania a nových príležitostí, ktoré mal tento urbánny svet ponúkat'. Realita v mestách však bola odlišná. Napriek tomu, že urbánne prostredie bolo štedrejšie na ponuku práce, často šlo o prácu bez úväzkov a vel'mi zle platenú. Väčšina Maoriov nebola dostatočne kvalifikovaná na prácu, ktorú vykonávali, a tomu zodpovedala aj finančná odmena. V mestách tak začali vznikat' chudobné zóny, v ktorých sa Maoriovia sústred'ovali bez prostriedkov na kontakt so svojimi domovskými oblast'ami. Kmeňové spoločenstvá, ktoré ostávali v rurálnych oblastiach, si často nemohli dovolit' podporovat' tých v mestách (finančne ani duchovne), a tí tak ostali vytrhnutí z komunity, ktorá by podporovala rozvoj ich kultúrnej a etnickej identity. Akulturačný a asimilačný tlak majoritnej spoločnosti spôsobil, že v urbánnom prostredí vznikli generácie tzv. mestských Maoriov (Urban Maori), ktorí neboli schopní sa kultúrne identifikovat' ako Maoriovia a zároveň boli vystavení rasizmu a odmietnutiu dominantnou kultúrou. BISTÁROVÁ, Lucia. Bojovníci z krajiny Dlhého bieleho oblaku. P̛̊vodni obyvatelé a globalizace. Pardubice: Pavel Mervart, 2021.

${ }^{36}$ DURIE, Mason. Te Mana, Te Kawanatanga - The politics od Maori Self-Determination. Auckland: Oxford University Press New Zealand, 1998, s.57.

${ }^{37}$ DODD, Carley H. Dynamics of intercultural communication. Iowa: Brown \& Benchmark Publishers, 1995 , s.35.

${ }^{38}$ BARŠA, Pavel a STRMISKA, Maximilián. Národní stát a etnický konflikt. Brno: Centrum pro studium Demokracie a Kultury, 1999, s.67.
} 
(hapu) a rodine (whanau), vzt'ahujúca sa na určitú lokalitu - kmeňové územie. ${ }^{39}$ Kultúrna identita, rovnako ako etnická, pôsobí teda ako zjednocujúce kritérium, ktoré zahíňa zdiel'anú kultúru, jazyk a územie.

Úsilie o zachovanie či revitalizáciu kultúry a d’alší rozvoj etnických menšín je však treba v prípade Maoriov vidiet' $\mathrm{v}$ súvislosti $\mathrm{s}$ ich existenciou v priestore bikultúrnej spoločnosti súčasného globalizovaného Nového Zélandu a jeho zdielanej maorijskoeurópskej kultúrnej identity. Šatava uvádza ako príklad koncepciu „,nie len - ale aj “, ktorá sa vzt’ahuje na etnicitu a jazyk v multikultúrnom priestore, ktorého spoločným záujmom je koexistencia minoritnej a majoritnej zložky spoločnosti. Dôraz je $\mathrm{v}$ tomto prípade kladený predovšetkým na kultúrne a jazykové aspekty, väzba na etnickú identitu je menej podstatná, pretože jazyk je považovaný za kultúrny kapitál etnika, aj ked' je obvykle označovaný za hlavný znak etnicity. ${ }^{40}$

U jednotlivcov, ale i celých spoločností v multikultúrnom priestore je stále bežnejšia rovina dvojitých, alebo multiplikovaných identít (multiple identities), ktoré sú výraznejšie (viac alebo menej), v závislosti od okolností v ktorých sa nositel’ nachádza. U väčšiny Maoriov je možné, aj vd’aka jazyku a silnej kultúrnej emancipácii, vel'mi jasne stanovit' hranicu medzi „maorijským“, „novozélandským“ alebo “euro-novozélandským”, v zmysle dichotomického etnického vymedzenia „my“ verzus „oni““. 41

Adam Kuper uvádza, že každá komunita má svoju vlastnú kultúru, so svojimi vlastnými špecifikami a hodnotami, ktoré ju odlišujú od ostatných. Upozorňuje však na to, že táto kultúra neodkazuje na uniformitu jej nositel'ov. Kultúra, podobne ako etnicita nevysvetl'uje zásadné vlastnosti l’udí, ani spôsob, akým žijú svoj život. ${ }^{42}$ V jednotlivých skupinách totiž neexistuje homogenita a preto neexistuje ani jediný „správny“ spôsob ako byt’ Maori. $^{43}$

Pri získavaní stabilnej etnickej či kultúrnej identity, musia mat’ jej nositelia nielen prístup k svojmu kultúrnemu dedičstvu a pocit kolektívnej spolupatričnosti, ale aj možnost' slobodného kultúrneho prejavu a podpory tejto kultúry $\mathrm{v}$ spoločenských inštitúciách. Potlačenie týchto prejavov môže totiž viezt' ku strate kultúrnej identity, pocitu

\footnotetext{
${ }^{39}$ KOLLÁROVÁ, Lubica. Kultúrna identita pôvodných obyvatel’ov Nového Zélandu. [diplomová práca. Školitel': PhDr. Viktor Krupa, DrSc.]. Trnava: s.n., 2002, s.50.

${ }^{40}$ ŠATAVA, Leoš. Etnicita a jazyk - Teorie, praxe, trendy: Č́tanka textů. s.1.: Tribun EU, 2013, s. 25.

${ }^{41}$ Tamtiež, s. 26.

${ }^{42}$ KUPER, Adam. Culture. The Anthropologist's Account. Cambridge: Harvard University Press, 1999, s. 16.

${ }^{43}$ DURIE, Mason. Imprisonment, Trapped Lifestyles, and Strategies for Freedom. Ngā Kāhui Pou: Launching Māori Futures. Wellington: Huia Publishers, 2003, s.59.
} 
spolupatričnosti a sebaúcty, s negatívnym dopadom na oblasti zdravotného štandardu, vzdelania a spoločenského postavenia Maoriov. ${ }^{44}$

Pri zhrnutí tohto popisu môže teda koncept kultúrnej identity jasne naznačovat', že Maoriovia kolonizáciou a následným procesom akulturácie, pod tlakom kultúry dominantného kolonizujúceho národa, definitívne alebo dočasne stratili určité aspekty svojej kultúry ${ }^{45}$, čo mohlo viezt' k negatívnym dôsledkom, akými sú už spomínaná marginalizácia, frustrácia a následne protispoločenské tendencie (kriminálna aktivita). Štúdium týchto koncepcií, ale aj terénny výskum v komunite novozélandských Maoriov, naznačuje, že rozvoj kultúrnej identity a etnického sebaurčenia pozitívne vplýva na správanie Maoriov, predovšetkým vobdobí dospievania, a môže zmiernit' asociálne postoje, nezáujem o vzdelanie a tendencie združovania sa $\mathrm{v}$ gangoch, ktoré $\mathrm{v}$ mnohých prípadoch môžu viezt' ku kriminálnej aktivite.

\section{Formovanie identity prostredníctvom príslušnosti ku gangu}

Vznik gangov je v súčasnosti všeobecne spájaný s problémom chudoby v mestských štvrtiach, sociálnej segregácie vychádzajúcej z odlišnosti náboženstva, sociálnej triedy, či etnickej príslušnosti. Gangy sú tvorené skupinami (prevažne) mladých mužov, ktorí sa cítia vyradení z bežnej spoločnosti, je im odopretá dôstojná práca, majú zlé rodičovské vzory a podobne. Členstvo v týchto gangoch pre nich predstavuje zmysel života, ktorý v majoritnej spoločnosti a predovšetkým problémových rodinách nižšej spoločenskej triedy nenachádzajú. Člen má pocit bezpečia, ochrany a v priestoroch, kde gang pôsobí, nachádza útočisko $\mathrm{v}$ čase potreby. ${ }^{46}$

Opakovaný terénny výskum potvrdil teóriu, ktorá naznačuje, že ak Maoriovia nezískajú stabilnú identitu tým, že sú súčast'ou komunity jednotlivých whanau hladajú náhradnú identitu niekde inde. ${ }^{47}$ Ked' nie sú schopní si nájst', alebo udržat' pocit

\footnotetext{
${ }^{44}$ Tamtiež, s.69-70.

${ }^{45}$ Spoločenský, ale aj legislatívny tlak anglicky hovoriacej väčšiny v krajine spôsobil takmer úplné vymretie pôvodného jazyka. Ďalším dôležitým kultúrnym aspektom Maoriov bolo napr. tradičné tvárové tetovanie ta moko, ktoré bolo považované za barbarské a už samotná vizuálna podstata bola stigmou, nakol'ko Maoriovia s tvárovým tetovaním si v novom svete Pakehov nevedeli nájst' prácu a vylúčenie zo spoločnosti bolo ešte intenzívnejšie ako u nepotetovaných Maoriov. Už spomínaný zákon The Tohunga Susspession Act, zakazujúci akúkol'vek duchovnú alebo vzdelávaciu aktivitu kňazov tohunga, znemožnil Maoriom akokol'vek praktizovat' ich kultúru pod hrozbou finančných sankcií a tak ich jazyk, umenie a kultúra boli pod tlakom koloniálnej vlády Pakehov vytlačené na perifériu spoločnosti. DUFF, Alan. Maori: the crisis and the challenge. Auckland: Harper Colins Publishers, 1993.

${ }^{46}$ KINNEAR, Karen L. Gangs: A Reference Handbook. 2009, s.7.

${ }^{47}$ WINTER, Pahmi. Pulling the Teams Out of the Dark Room: The Politicisation of the Mongrel Mob. Gangs and Youth Subcultures. New York: Routledge, 1998, s.247.
} 
spolupatričnosti prostredníctvom genealogických väzieb používaním maorijského jazyka a nasledovaním kultúrneho protokolu Maoriov - tikanga Maori ${ }^{48}$, môžu hl'adat' alternatívnu cestu $\mathrm{k}$ dosiahnutiu pocitu spolupatričnosti napríklad prostredníctvom príslušnosti k niektorému z gangov. ${ }^{49}$

Newbold a Taonui, vo svojej štúdii o novozélandských gangoch, uvádzajú, že v súčasnosti je v krajine približne 46 aktívnych gangov s cca 20000 členmi, z ktorých viac ako 7000 je riadne iniciovaných (aktívne sa podiel'a na činnosti gangu). ${ }^{50}$

Podla výsledkov štatistík Ministerstva spravodlivosti Nového Zélandu (Department of Corrections: Ara Poutama Aotearoa) sú v súčasnosti aktívne gangy tvorené predovšetkým Maormi, alebo prist'ahovalcami z okolitých ostrovov (Pacific Islanders), a tvoria tak tzv. etnické gangy. ${ }^{51}$ Vel'ká väčšina aktívnych členov gangov je príslušníkmi niektorého $z$ troch najväčších gangov Black Power, Mongrel Mob, alebo Nomads. Napriek tomu, že Mongrel mob, ktorý je v súčasnosti najväčším gangom v krajine, nie je výlučne etnický (maorijský), väčšina jeho členov je práve maorijského pôvodu.

Gilbert uvádza, že gangy vznikajú prevažne v deprivovaných komunitách menšín, ktoré boli, alebo sú vystavované marginalizácii a strate etnickej emancipácie, hrdosti a spolupatričnosti. Následkom kolonizačnej politiky mnohí Maoriovia stratili znalosti svojich genealogických línií a pocit príslušnosti nielen $\mathrm{k}$ jednotlivým whanau, ale všeobecne k svojmu etniku. Práve gang môže nahradit' rodinnú bunku a poskytnút' útočisko a podporu $\mathrm{v}$ čase potreby. Gangy sa v súčasnosti stávajú útočiskom mladých Maoriov, ktorí majú problém sa kultúrne alebo etnicky identifikovat' a stat' sa plnohodnotnou súčast'ou spoločnosti. $^{52}$

Podl'a Ministerstva sociálneho rozvoja (Ministry of Social Development: Te Manatu Whakahiato Ora) Maoriovia, ktorí stratili podporu svojej rozšírenej rodiny whanau a nie sú schopní sa kultúrne identifikovat', sú najčastejšie motivovaní k tomu, aby sa pridali ku gangu. ${ }^{53}$ Eggleston uvádza, že príslušnost’ou $\mathrm{k}$ takémuto gangu jednotlivec často nachádza

\footnotetext{
${ }^{48}$ tikanga Maori je súbor zvykov - kanón maorijských zvyklostí (napr. zvyky spojené so smrtou, narodením diet’at’a a iných významných udalostí v živote človeka) a správania sa.

${ }^{49}$ CHALMERS, Tess. Exploring Māori Identity Behind Closed Doors: An investigation of Māori cultural identity and offender change within Waikeria Prison's Maori Focus Unit, Te Aa Marama. 2014, s.46.

${ }^{50}$ NEWBOLD, Greg a TAONUI, Rawiri. Gangs - Gangs and Crime; Te Ara - the Encyclopedia of New Zealand [online]. 2011 [cit. 2021-01-27]. Dostupné z: https://teara.govt.nz/en/gangs/page-4.

${ }^{51}$ Community sentences and order. Department of Corrections [online]. 2021 [cit. 2021-01-27]. Dostupné z: https://www.corrections.govt.nz/resources/research_and_statistics.

${ }^{52}$ GILBERT, Jarrod. Patched: The History of Gangs in New Zealand. Auckland: Auckland University Press, 2013, s.5.

${ }^{53}$ EGGLESTON, Erin, J. Ministry of Social Development: New Zealand Youth Gangs: Key Findings and Recommendations from an Urban Ethnography [online]. Social Policy Journal of New Zealand (14), 2000 [cit.
} 
novú formu rodiny a široký priestor pre demonštráciu etnickej identity. Podl’a jeho teórie bola práve túžba po spolupatričnosti prvotným motívom vzniku gangov a identita dôležitou súčast'ou členstva $v$ týchto organizáciách. ${ }^{54}$

Ako už bolo uvedené, maorijská etnická identita nevzniká automaticky, len tým, že niekto je členom etnickej skupiny. Priamo súvisí s kultúrnou identitou jedinca, ktorej markery sú aj v súčasnosti považované za základné komponenty maorijskej identity.

Maorijské komunity tiež vyžadujú aktívnu účast' jednotlivcov na komunitných záležitostiach. Touto účast’ou jednotlivec potvrdzuje svoju etnickú identitu, a tiež získava uznanie zvyšku kolektívu. $^{55}$

Tento proces vytvorenia a validácie identity je možné pozorovat' práve pri maorijských gangoch. Akékol'vek kultúrne znalosti a praktiky, ktoré si tieto skupiny osvojili (napr. spôsob tvárového tetovania, zvyky spojené s významnými udalost’ami v živote (smrt’ uctenie si pamiatky zosnulého), spoločenská organizácia a hierarchizácia, iniciácia, regionálne delenie atd’) sú čiastočne pretvorené, vychádzajú z pôvodných maorijských kultúrnych zvyklostí ${ }^{56}$ a dá sa povedat', že priamo nahrádzajú u svojich členov kultúrne markery, na základe ktorých sa môžu identifikovat' jednak ako členovia gangu, ale aj ako Maori.

Počas môjho výskumu bolo zrejmé, že viacerí respondenti mali obmedzené znalosti kultúrneho protokolu tikanga Maori, niektorí plynule neovládali maorijský jazyk a nezapájali sa do kultúrnych aktivít. Z rozhovorov jednoznačne vyplývalo, že ich hodnoty, ako aj schopnost' identifikovat' sa ako Maori, vychádzali z ich príslušnosti ku gangu, ktorý im poskytoval „kultúru“, pocit spolupatričnosti, formu whanau a zmysel či esenciu ich identity. V mnohých prípadoch bolo pozorované, že gang, ako organizácia, symbolicky nahrádzal predka, od ktorého by jednotlivec, alebo skupina tradične odvodzovali svoj pôvod. ${ }^{57}$

Vo svojom príspevku o Mongrel Mob, z roku 1998, Wintersová naznačuje, že vzhl'adom na nedostatočnú mieru kultúrneho povedomia väčšina regionálnych vetiev Mongrel Mob nenasleduje protokol tikanga, ani nejakým spôsobom neoslavuje a nestotožňuje sa so svojím kultúrnym dedičstvom. Uvádza ale aj príklad vetvy v Opotiky (východné pobrežie Severného ostrova), ktorej prezident Pat Aramoana intenzívne využíval a propagoval

2021-02-01]. Dostupné z: https://www.msd.govt.nz/about-msd-and-our-work/publications-resources/journalsand-magazines/social-policy-journal

54 Tamtiež.

${ }^{55}$ PARINGATAI, Karyn. Maori identity development outside of tribal environments. Aotearoa New Zealand Social Work Journal, 26(1). 2014, s.47

${ }^{56}$ HOBSBAWM, Eric a RANGER, Terence O. The Invention of Tradition. 1903.

${ }^{57}$ BISTÁROVÁ, Lucia. Terénny výskum. Nový Zéland, 2018. 
kmeňové hodnoty a zvyky, ktoré sa nenachádzali v lokálnej komunite, ako základ pre zlepšenie blahobytu svojich l'udí. ${ }^{58}$

Ďalším príkladom takejto kultúrnej zanietenosti je prezident vetvy Mongrel Mob v Hamiltone, v regióne Waikato, Sonny Fatupaito, ktorý má samoánsko-africký pôvod, avšak povzbudzuje príslušníkov svojej vetvy, aby si ctili a nasledovali maorijské tradičné zvyky vo všetkých aspektoch života. Fatupaito sám plynule hovorí maorijským jazykom a podporuje jeho rozvoj a učenie v komunite. V novembri 2019 zorganizoval Mongrel Mob Waikato „kultúrny workshop“, ktorý oslavoval nielen gang, ale aj maorijskú kultúru. Súčast’ou udalosti bolo oficiálne otvorenie marae ${ }^{59}$ určené pre whanau tohto gangu, ktoré má poskytovat' členom útočisko a zmysel pre lepší, účelnejší život, a popri tom reprezentovat' spolupatričnost', ktorú gang poskytuje. ${ }^{60}$

Pozoruhodný sled udalostí nastal po tragédii v novozélandskom meste Christchurch, kde 15. marca 2019 počas teroristického útoku na mešity prišlo o život 51 l'udí. Smútočné zhromaždenia v blízkosti miesta tragédie boli vtedy sprevádzané zvukom motoriek lokálnych gangov. Pri príležitosti vyjadrenia sústrasti si prezidenti rôznych (znepriatelených) gangov symbolicky podali ruky a na počest' obetí útoku predviedli maorijský tanec haka. Pre novozélandský denník NZ Herald celonárodný prezident Black Power Whenu McKinnon uviedol, že ,v časoch ako sú tieto, je potrebné odložit' bokom všetku vzájomnú zaujatost' a preukázat' solidaritu a podporu tak, ako to káže tangi (rituály spojené so smrtou, pozn. autora). “ 61 „Je to maorijský spôsob vyrovnávania sa so smrtou, maorijský spôsob ako vyjadrit' smútok. Je to maorijský spôsob ako vyjadrit' lásku, “ uviedol zas profesor z Univerzity vo Waikato (University of Waikato) Te Kahautu Maxwel. ${ }^{62}$

Takáto výzva k solidarite a nasledovaniu kultúrneho protokolu síce nepredstavuje riešenie problému, ktorým gangy bezpochyby sú, avšak potvrdzuje rolu gangu pri formovaní

\footnotetext{
${ }^{58}$ WINTER, Pahmi. Pulling the Teams Out of the Dark Room: The Politicisation of the Mongrel Mob. Gangs and Youth Subcultures. New York: Routledge, 1998, s.256.

${ }^{59}$ Marae je komplex niekol'kých budov a pozemkov, ktoré patria určitému kmeňu. Pre hlavnú budovu je typický ozdobne vyrezávaný drevený štít. Marae predstavuje centrum rituálneho života jednotlivých maorijských komunít kmeňovej podstaty. Poskytuje priestor pre prerokovanie záležitostí týkajúcich sa ich komunity, oslavy a dôležité životné udalosti, vzdelávanie a pod. DURIE, Mason. Te Mana, Te Kawanatanga - The politics od Maori Self-Determination, s. 221.

${ }^{60}$ SAVAGE, Jared. Inside a Mongrel Mob workshop. In: NZ Herald [online]. 2019 [cit. 2021-02-02]. Dostupné z: https:/www.nzherald.co.nz/nz/inside-a-mongrel-mob-workshop/.

${ }^{61}$ Mass haka and waiata performed outside Christchurch mosque to honour shooting victims. In: NZ Herald [online]. 2019 [cit. 2021-02-02]. Dostupné z: https:/www.nzherald.co.nz/nz/mass-haka-and-waiata-performedoutside-christchurch-mosque-to-honour-shooting-victims/.

${ }^{62}$ CLIFFTON, Katy. Mongrel Mob biker gang turns up to guard New Zealand mosque during Friday prayers and are cheered as they perform haka outside. In: Evening Standard [online]. 2019 [cit. 2021-02-02]; dostupné na: https://www.standard.co.uk/news/world/.
} 
kultúrnej a etnickej identity jej členov. Na princípe rozvoja maorstva (Maoridom) bol založený aj sociálny program premiéra Roberta Muldoona z konca 70. rokov, ktorý mal pomôct' vyriešit' problém gangov na Novom Zélande. ${ }^{63} \mathrm{~V}$ spolupráci s doživotným členom Black Power Denisom O’Reillym bol za účelom vytvorenia stratégie znižovania kriminality maorijskej mládeže založený oddiel terénnych sociálnych pracovníkov. Poslaním týchto sociálnych pracovníkov bolo vzdelávat' mládež v gangoch (aj) v oblasti maorijského kultúrneho dedičstva, čo malo poskytnút' členom nové perspektívy a možnosti sebaidentifikácie, zníženie miery kriminality $\mathrm{v}$ týchto komunitách, budovanie prospoločenského zmýšl’ania a následne zlepšenie kvality života členov gangu. ${ }^{64}$

Napriek rozporuplným názorom ohl’adom účinnosti Muldoonovho programu ako takého, pôvodná myšlienka rozvoja a posilnenia kultúrnej identity sa v problémových maorijských komunitách, väzenských a nápravno-výchovných zariadeniach ukázala ako funkčná a stala sa inšpiráciou pre viaceré reedukačné programy. ${ }^{65}$

\section{Záver}

Ciel’om tohto príspevku bolo preukázat' význam gangu pri formovaní a rozvíjaní etnickej a kultúrnej identity mladých Maoriov, zo sociálne znevýhodneného prostredia, ktorí žijúc v mestách - d’aleko od tradičného vidieckeho prostredia, nedokážu nájst' iný spôsob ako sa identifikovat' ako Maori, než byt' súčast'ou gangu. Pri dokazovaní stanoveného ciel’u bolo nevyhnutné zodpovedat' otázku, prečo tieto skupiny v krajine vznikli v prvom rade, a ako je možné, že aj v súčasnosti predstavujú vážny problém v spoločnosti Nového Zélandu.

\footnotetext{
${ }^{63}$ Problémy gangov vrcholili na Novom Zélande koncom 70. rokov 20. storočia. Protest voči koloniálnej politike, málo práce pre l'udí v mestách a následne zhoršujúca sa sociálna situácia robotníckej triedy, mali na svedomí zvyšovanie kriminality gangov, ozbrojené bitky, znásilnenia, vraždy, mnohopočetné napadnutia civilistov aj príslušníkov polície, ktoré otriasali spoločnost’ou Nového Zélandu. Následkom tejto delikvencie boli prijatia rôznych legislatívnych opatrení a zákonov, ktoré mali zabránit', alebo obmedzit' kriminálnu činnost' gangov. Viac: GILBERT, Jarrod. The Rise and Developement of Gangs in New Zealand. Christchurch: University of Canterbury Press, 2010, s.277-346.

${ }^{64}$ GILBERT, Jarrod. The Rise and Developement of Gangs in New Zealand. 2010, s.331.

${ }^{65}$ Motivačné programy tikanga (Motivational tikanga Maori programmes) sú zriad'ované za podpory Ministerstva spravodlivosti (Department of Corrections: Ara Poutama Aotearoa) a zahŕňajú širokú škálu kultúrne smerovaných a motivačných programov pre problémové komunity a zverencov maorijského pôvodu. Úlohou tikanga programov je motivovat' týchto jedincov $\mathrm{k}$ snahe o pochopenie ich kultúrnej identity a nasledovanie zásad správania sa, ktoré tikanga obsahuje. Sú koncipované tak, aby pomáhali jednotlivcom určit' príčiny ich protispoločenského správania a rozvinút' stratégie, ktoré im zabránia $v$ páchaní d’alších trestných činov. Programy poskytujú rôzne edukačné štýly a aktivity môžu obsahovat' diskusie, oboznamovanie sa s protokolom tikanga, a tiež nácvik rôznych perfomancií, napr. vel'mi známa kapa haka. CAMPBELL, Neil. Department of Corrections: The Department of Corrections' tikanga-based programmes [online]. Practice: The New Zealand Corrections Journal, 4(2), 2016 [cit. 2021-02-01]. Dostupné z: https://www.corrections.govt.nz/resources/newsletters_and_brochures/journal/.
} 
Ako bolo v príspevku preukázané, akulturačné tlaky zo strany majority európskeho pôvodu a následná degradácia kultúry a životnej úrovne vel'kej časti Maoriov, mali za následok vznik sociálne výrazne horšie situovanej vrstvy spoločnosti. Stále zhoršujúca sa socio-ekonomická situácia $\mathrm{v}$ priebehu 60. a 70. rokov 20. storočia viedla k vzniku a rozmachu delikventných skupín, ktoré sa stali permanentnou súčast'ou spoločnosti Nového Zélandu.

Gangy, hlboko zakorenené v spoločnosti a predovšetkým komunitách Maoriov, predstavujú akési inštitúcie, v ktorých mnohí vyrástli, alebo dokonca zostarli. Novozélandské gangy boli pôvodne tvorené mladými rozhnevanými chlapcami, ktorých vek často nepresahoval 20 rokov. Mat' kriminálnu zložku bolo súčast'ou imidžu a gangovej scény a ich členstvo bolo o tom „byt' zlý“،. V súčasnosti majú títo muži 60 - 70 rokov a ich pohl’ad na svet, ale aj na spoločnost', v ktorej žijú sa zmenil. Z rozhnevaných chlapcov sa stali muži, ktorí majú vlastné rodiny, deti, vnúčatá a ohliadajúc sa spät’, za búrlivým životom „,na hrane“, túžia po lepšej budúcnosti pre svojich potomkov.

Začiatkom 90. rokov 20. storočia pozorujeme v prípade viacerých gangov akési „dozrievanie“, resp. vývoj gangov, ktorý podnietil zmenu skupín „,rozhnevaných mužov“ na inštitucializované, sofistikovanejšie organizácie. ${ }^{66}$ Tieto inštitucionalizované gangy pretrvali v spoločnosti napriek zmenám vo vedení, kedy čelili strate vodcov a potrebe určit' nových bez toho aby sa rozštiepili na menšie. Pretrvali aj napriek tlaku vlády a zvyšku spoločnosti na ich potlačenie či zničenie. Legislatívne zmeny, policajné represie a sociálne programy tiež nezaručili, aby gangy zo spoločnosti zmizli, ale bezpochyby mali za následok ich vývoj a mnohostranné zmeny. Z týchto zmien nemožno ignorovat', že organizácia a pravidlá gangov sa prestali dotýkat' len samotných členov a poskytli priestor pre vytvorenie úloh a rozličných rolí aj pre ich okolie, ako napr. rodina členov. Gangy začali plnit' nové funkcie a služby pre širšiu komunitu, akými sú napr. ekonomická podpora, ochrana a programy, ktoré sú prínosom nie len pre gangy a členov, ale aj pre ich okolie. ${ }^{67}$

\footnotetext{
${ }^{66}$ HAGEDORN, John M. The Global Impact of Gang. Journal of Contemporary Criminal Justice, 21 (2), s.153169. 2005, Sage Publications, s.162.

${ }^{67} \mathrm{Z}$ týchto môžem uviezt' niektoré, ktorých svedkom som bola počas pobytu v teréne a považujem ich za dôkaz zmeny povahy gangov a ich pozitívneho prínosu pre spoločnost'. Aucklandský chapter Hells Angels každoročne $\mathrm{v}$ decembri organizuje pokrove turnaje a motorkársky zjazd s platenou účast'ou - Auckland Poker run. Finančný výtažok $\mathrm{z}$ tohto podujatia je následne venovaný aucklandskej rehabilitačnej klinike, na ktorej sa pred viacerými rokmi zotavoval jeden z príslušníkov. Obdobné podujatia a zjazdy organizujú viaceré gangy (Rebels, Nomads, Black Power) a podobne, zisk z podujatia je venovaný rôznych charitatívnym organizáciám, alebo na zaistenie jedla pre deti z chudobných rodín. Komunitné akcie gangy organizovali počas mojej prítomnosti napr. cez vianočné prázdniny (na Novom Zélande sú to dlhé letné prázdniny), kedy deti nechodili do školy, čo pre tie zo sociálne slabších rodín znamenalo, že nemali zaistené žiadne jedlo (školský nutričný program školopovinným det’om zabezpečuje jedno jedlo denne). V rámci spoločných osláv, tak bol poskytnutý priestor pre chudobné deti sa zadarmo najest', prípadne mohli dostat' malé darčeky, ktoré by si rodičia nemohli dovolit'.
} 
Gang začal predstavovat’ organizáciu, ktorá v rámci komunity, ktorá ich obklopuje vytvára určitý svetonázor. Jeho súčast'ou môžu byt' konkrétne pravidlá, ako je nosenie nášiviek a iných insígnií gangu, ale tiež môže íst' o pravidlá správania sa a nasledovania zvykov či rituálov v rámci tikanga Maori (súbor pravidiel tradičnej maorijskej kultúry), ako sú napr. zvyky spojené so smrt’ou, či pohostinnost' a zdiel'anie jedla. Gangy pri príležitosti úmrtia niektorého z členov organizujú pohreby podl'a pravidiel tangihanga (pravidlá a zvyky spojené s úmrtím), kedy sa príslušníci z celej krajiny zídu, aby si uctili pamiatku zosnulého. Opísané venovanie financií a jedla je zas súčast’ou mravného kódexu manaakitanga (pohostinnost'), ktorý (okrem iného) káže zdiel'at' jedlo s tými, ktorí to potrebujú. Napriek tomu, že sa gangy od ich vzniku takto radikálne zmenili a mnohé z nich sa v súčasnosti angažujú vo veciach rozvoja prosperity a zlepšovania podmienok v chudobných komunitách, ich história a kriminálna podstata stále vyvolávajú množstvo pochybností a negatívnych konotácií.

Zmena povahy gangov, ich pro-komunitné aktivity a rastúca popularita, ktoré v posledných 10-20 rokoch pozorujeme, môžu byt' pre mnohých prínosom, avšak sú len výsledkom predchádzajúcich desat'ročí zlyhávania vlády vo veci zabezpečovania zlepšenia sociálneho postavenia Maoriov. Nie je teda prekvapením, že sa signifikantná čast' maorijskej mládeže (aj v súčasnosti) utieka o „pomoc“, ktorú nenachádza v systéme, práve ku gangom. Propagácia tradícií, kmeňových hodnôt a zvykov, ktoré často v sociálne znevýhodnených mestských komunitách absentujú, sa ukázali v gangoch ako účelové, a tak mnohé z vetiev gangov môžu plnit' funkciu komunite prospešnej organizácie. Nesmieme však zabúdat' na nezanedbatel'nú čast' členov a ich blízkych, na ktorých gang takýto pozitívny dopad nemá.

Násilie, drogy, alkohol a kriminalita sú veci, ktoré sú často práve tým dôvodom, prečo sa jednotlivci ku takémuto gangu pridajú a sú každodennou súčast'ou ich existencie. $\mathrm{Na}$ každého člena gangu pripadá rodina, tvorená partnerkou, alebo partnerom, det'mi a tými, ktorí sú im blízki. Vel'mi vel'ká čast' z nich, je konfrontovaná problémami a násilím, ktoré gangy obklopujú. V každej takejto rodine vyrastajú generácie, na ktoré má toto násilné chovanie dopad. U diet'at'a z rodiny, kde bol aspoň jeden rodič trestne stíhaný, je sedemnásobne vyššia pravdepodobnost', že skončí vo väzení tiež. ${ }^{68}$ A tento kolobeh sa stále opakuje. Vysoká miera chudoby, kriminality a domáceho násilia je niečo, čo sa stalo v národných štatistikách Maoriom vlastné. Štatistiky Ministerstva spravodlivosti uvádzajú, že členovia gangov majú

\footnotetext{
${ }^{68}$ Community sentences and order. Department of Corrections [online]. 2020 [cit. 2021-01-27]. Dostupné z: https://www.corrections.govt.nz/resources/research_and_statistics.
} 
vyššiu mieru odsúdenia za násilné činy v porovnaní s páchatel’mi, ktorí v gangoch nie sú. ${ }^{69}$ Akokol'vek prospešná, v oblasti formovania kultúrnej a etnickej identity Maoriov, tak môže príslušnost' ku gangom byt', nedá sa popriet' aj ich negatívny vplyv na správanie členov, prevažne to kriminálne. Nadobudnutý zmysel pre maorijskú kultúrnu identitu tak môže byt' konfrontovaný s kriminálnou identitou, rovnako získanou príslušnost’ou ku gangu.

Novozélandský sociológ Jarrod Gilbert, ${ }^{70}$ ktorý sa zaoberá problematikou maorijských gangov, dlhodobo vyzýva k zmene prístupu k týmto problémovým skupinám. Uvádza, že pokusy o rozbitie organizovaných gangov sa ukázali naprieč históriou ako zbytočné a napriek všetkým snahám a politickým sl’ubom, ostal tento problém nevyriešeným. Naopak prokomunitný prístup viacerých gangov viditel'ne zvýšil ich popularitu v komunitách a záujem mladých Maoriov o členstvo. Gilbert tvrdí, že autorita, ktorú gangy predstavujú, by mohla byt' využitá $\mathrm{v}$ prospech budovania stratégie zlepšovania spoločenského postavenia vylúčených komunít. Problém podl'a neho nepredstavujú gangy ako také, ale ich protizákonné aktivity, ktoré by sa mohli časom zredukovat' na minimum, ak by bola vláda ochotná spolupracovat' s pro-komunitne zameranými vodcami gangov, ktorí v komunitách predstavujú vodcovskú autoritu. Zodpovedné orgány by sa preto nemali zameriavat' na problém existencie gangov, ale jednotlivé sociálno-patologické javy, ktoré môžu, ale nemusia byt' ich súčast'ou. ${ }^{71}$

Aj ked' nie je možné prehliadat' kriminálnu podstatu gangov a teror, ktorý sa $\mathrm{s}$ ich minulost'ou spája, pre pochopenie ich úlohy pri formovaní etnickej a kultúrnej identity je potrebné tieto skutočnosti vnímat' v kontexte akulturačného tlaku koloniálnej politiky, ktorý bol jedným z dôvodov ich vzniku. Úlohou vedcov nie je pripisovat' niekomu, alebo niečomu, podiel viny na vzniku protispoločenských skupín, ale nájst' dôvody a vysvetlit' ich. Absencia kultúrnej identity u Maoriov a ich oslabená, alebo utlačená etnická hrdost' sa ukázali ako jeden z hlavných dôvodov degradácie kultúry a životnej úrovne pôvodných obyvatel'ov Nového Zélandu. Gangy vznikali ako jeden z dôsledkov zhoršovania sa životnej úrovne mladých l'udí, ktorí sa takouto formou stavali na odpor koloniálnej politike. Mnohé gangy na tento protest využili napr. spoločnost'ou neakceptované (v maorijskej tradičnej kultúre významné) tvárové tetovania, ktoré mali jasne preukázat' ich pôvod a vzdor, čím prinavrátili

\footnotetext{
69 Tamtiež.

${ }^{70}$ Jarrod Gilbert je vysokoškolský pedagóg a vedecký pracovník na univerzite v Canterbury. Je hlavným výskumným pracovníkom spoločnosti Independent Research Solutions. Vypracoval množstvo štúdií o trestnej činnosti, so zameraním na ich praktickú aplikáciu. Je autorom knihy Patched: the History of Gangs in New Zealand (História gangov na Novom Zélande), ktorá je výsledkom šest'ročného výskumu gangov na Novom Zélande.

${ }^{71}$ Zdroj: GILBERT, Jarrod. Gangs are Changing... We should too. Radio New Zealand [rozhovor]. 2018 [cit. 2021-01-27]. Dostupné z: https:/www.rnz.co.nz/series/ on-the-inside/.
} 
tetovaniu jeho sociálny a kultúrny rozmer, v zmysle znovuobjavených tradícií. Etnické gangy sa stali útočiskom pre mnohých, ktorí boli odvrhnutí spoločnost'ou Pakehov, ale mnohokrát aj samotných Maoriov. Poskytli im útočisko, ochranu a spôsob pre znovuobjavenie maorstva, ktoré v europeizovanej spoločnosti nenachádzali.

Nasledovanie protokolu tikanga Maori je iniciované a podporované vodcami gangov, čo u členov posilňuje kultúrnu identitu a etnickú hrdost'. Mnoho z vodcov verí, že rozvoj kmeňových hodnôt a zvykov (a teda rozvoj kultúrnej identity) u členov gangu, môže predstavovat' základ pre zlepšenie blahobytu aj pre ich okolie. Gangy plne nahrádzajú tradičné kmeňové komunity pre tých, ktorí v mestách stratili kontakty so svojím pôvodným whanau, predstavujú akýchsi garantov správania sa a podporujú ich kultúrny rozvoj. V tomto slova zmysle je členstvo v gangu významným prínosom vo veci formovania etnickej a kultúrnej identity a hrdosti Maoriov, ktorý nie je možné popriet' a ani prehliadat'. 


\section{Zoznam použitých zdrojov}

BARŠA, Pavel a STRMISKA, Maximilián. Národní stát a etnický konflikt. Brno: Centrum pro studium Demokracie a Kultury, 1999.

BARTH, Frederik. Ethnic Groups and Boundaries: The Social Organization of Culture Difference. Boston: Little, Brown and Company, 1969, s. 13.

Behavioral Scientist 40(2) [online]. 1996, s. 143-152. 143-152 [cit. 2021-10-04]. Dostupné z: https://journals.sagepub.com/doi/10.1177/0002764296040002005.

BISTÁROVÁ, Lucia. Bojovníci z krajiny Dlhého bieleho oblaku. Původní obyvatelé a globalizace. Pardubice: Pavel Mervart, 2021.

CAMPBELL, Neil. Department of Corrections: The Department of Corrections' tikangabased programmes [online]. Practice: The New Zealand Corrections Journal, 4(2), 2016 [cit. 2021-02-01]. Dostupné z:

https://www.corrections.govt.nz/resources/newsletters_and_brochures/journal/.

CLIFFTON, Katy. Mongrel Mob biker gang turns up to guard New Zealand mosque during Friday prayers - and are cheered as they perform haka outside. In: Evening Standard [online]. 2019 [cit. 2021-02-02]; dostupné na: https://www.standard.co.uk/news/world/. Community sentences and order. Department of Corrections [online]. 2020 [cit. 2020-08-07].

DODD, Carley H. Dynamics of intercultural communication. Iowa: Brown \& Benchmark Publishers, 1995.

Dostupné z: https://www.corrections.govt.nz/resources/research_and statistics.

DUFF, Alan. Maori: the crisis and the challenge. Auckland: Harper Colins Publishers, 1993.

DURIE, Mason. Imprisonment, Trapped Lifestyles, and Strategies for Freedom. Ngā Kāhui Pou: Launching Māori Futures. Wellington: Huia Publishers, 2003, s. 59-73.

DURIE, Mason. Te Mana, Te Kawanatanga - The politics od Maori Self-Determination. s.1.: Oxford University Press, 1998.

EGGLESTON, Erin, J. Ministry of Social Development: New Zealand Youth Gangs: Key Findings and Recommendations from an Urban Ethnography [online]. Social Policy Journal of New Zealand (14), 2000 [cit. 2021-02-01]. Dostupné z: https://www.msd.govt.nz/about-msd-and-our-work/publications-resources/journals-andmagazines/social-policy-journal/.

FERGUSSON, David M. Ethnicity and Interpersonal Violence in a New Zealand Birth Cohort. Violent Crime: Assessing Race and Ethnic Differences. Cambridge: Cambridge University Press, 2003, s. 138-153.

GILBERT, Jarrod a NEWBOLD, Greg. Youth Gangs: A review of the literature prepared for the Ministry of Social Development. Wellington: Ministry of Social Development, 2006.

GILBERT, Jarrod. Gangs are Changing... We should too. Radio New Zealand [rozhovor]. 2018 [cit. 2021-01-27]. Dostupné z: https://www.rnz.co.nz/series/ on-the-inside/.

GILBERT, Jarrod. Patched: The History of Gangs in New Zealand. Auckland: Auckland University Press, 2013.

GILBERT, Jarrod. The Rise and Developement of Gangs in New Zealand. Christchurch: University of Canterbury Press, 2010.

GRAY, Claire, JABER, Nabila a ANGLEM, Jim. Pakeha identity and whiteness: What does it mean to be white? Sites: New Series; 10(2). 2013.

HLÚŠEK, Radoslav. Špecifiká výskumu v domorodých komunitách v Mexiku. Terénny výskum v špecifickom prostredi. Trnava: UCM Trnava, 2015.

HOBSBAWM, Eric a RANGER, Terence O. The Invention of Tradition. Cambridge: Cambridge University Press, 1903. 
https://natlib.govt.nz/items?text=NZ+herald

https://www.nzherald.co.nz/search/gangs/

CHALMERS, Tess. Exploring Māori Identity Behind Closed Doors: An investigation of Māori cultural identity and offender change within Waikeria Prison's Maori Focus Unit, Te Aa Marama. Albany: Massey University, 2014.

JELEŇOVÁ, Iveta a SÁPOSOVÁ, Zlatica. Jazyk, Interetnické vzt’ahy a použivanie mad'arského jazyka v Košiciach. Košice: Centrum spoločenských a psychologických vied SAV, 2018.

KANOVSKÝ, Martin. Kultúrna a sociálna antropológia: Osobnosti a teórie. Bratislava: Chronos, 2004.

KARÁSEK, Matej. L'udskost' ako elementárna metóda (nie len v Indii). Terénny výskum v špecifickom prostredí. Trnava: Univerzita sv. Cyrila a Metoda v Trnave, 2015.

KINNEAR, Karen L. Gangs: A Reference Handbook. Santa Barbara: ABC-CLIO, LLC, 2009.

KOLLÁROVÁ, Lubica. Identita a jazyk dvoch hlavných zložiek novozélandskej spoločnosti: Maori a Pakeha. Brno: Tribun EU, 2013.

KOLLÁROVÁ, L’ubica. Kultúrna identita pôvodných obyvatel'ov Nového Zélandu. [diplomová práca. Školitel': PhDr. Viktor Krupa, DrSc.]. Trnava: s.n., 2002.

KOLLÁROVÁ, Lubica. Status a revitalizácia jazyka novozélandských Maoriov - Jazykje poklad. [Online] 2003 [cit. 2021-01-27]. Dostupné z: is.cuni.cz > webapps > zzp > download.

KUPER, Adam. Culture. The Anthropologist's Account. Cambridge: Harvard University Press, 1999.

METGE, Joan. A new Maori migration: Rural and urban relations in northern New Zealand. London: The Athlone Press, 1964.

MOORE, Joan W., et al. Homeboys: Gangs, drugs, and prison in the barrios of Los Angeles. Philadelphia: Temple University Press, 1978.

MOORE, Joan, W. Going Down to The Barrio: Homeboys and Homegirls in Change. Philadelphia: Temple University Press, 1991.

National Library: Topic: NZ Herald [online]. Archív. [cit. 2021-04-22]. Dostupné z:

New Zealand Acts As Enacted: Native Rights Act 1865 (29 Victoriae 1865 No 11) [online]. 2020 [cit. 2021-01-26]. Dostupné z: http://www.nzlii.org/nz/legis/hist_act/nra186529v1865n11281/.

New Zealand Herald: Searched topic: Gangs [online]. Archív. [cit. 2021-04-22]. Dostupné z:

NEWBOLD, Greg a TAONUI, Rawiri. Gangs - Gangs and Crime; Te Ara - the Encyclopedia of New Zealand. [online] 2011[cit. 2021-01-27]. Dostupné z: https://teara.govt.nz/en/gangs/page-4.

NEWBOLD, Greg. Crime in New Zealand. Palmerston North: Dunmore Press Ltd, 2000.

PARINGATAI, Karyn. Maori identity development outside of tribal environments. Aotearoa New Zealand Social Work Journal, 26(1). 2014, s. 47-54.

PHINNEY, Jean S. Understanding ethnic diversity: The role of Ethnic identity. American PRŮCHA, Jan. Interkulturni psychologie. Praha: Portál, 2010.

REDFIELD, Robert, LINTON, Ralph a HERSKOVITS, Melville J. Memorandum for the Study of Acculturation. American Anthropologist, 38(1). [Online] 1936 [cit. 2021-0127]. Dostupné z: https://doi.org/10.1525/aa.1936.38.1.02a00330.

REICHEL, Jiří. Kapitoly metodologie sociálních výzkumů. Praha: Grada, 2009.

SAVAGE, Jared. Inside a Mongrel Mob workshop. In: NZ Herald [online]. 2019 [cit. 2021 02-02]. Dostupné z: https://www.nzherald.co.nz/nz/inside-a-mongrel-mob-workshop/. 
SPRADLEY, James. The Ethnographic Interview. New York: Holt, Rineheart, and Winston, 1979.

Stats New Zealand [online]. Cenzus. 2020 [cit. 2020-08-22]. Dostupné z: https://www.stats.govt.nz/topics/census.

ŠATAVA, Leoš. Etnicita a jazyk - Teorie, praxe, trendy: Čítanka textů. s.1.: Tribun EU, 2013.

THRASHER, Frederic M. The Gang: A Study of 1,313 Gangs in Chicago. Chicago: University of Chicago Press, 1927.

VIGIL, James, D. Barrio Gangs: Street life and identity in Southern California. Austin: University of Texas Press, 1988.

WINTER, Pahmi. Pulling the Teams Out of the Dark Room: The Politicisation of the Mongrel Mob. Gangs and Youth Subcultures. New York: Routledge, 1998, s. 245-267. 


\title{
The Xinjiang Uyghur Autonomous Region as an example of separatism in China
}

\author{
Dru C. Gladney \\ Pomona College, 333 N. College Way, Claremont, CA 91711, USA
}

DOI: https://doi.org/10.7160/KS.2021.160105

Prof. Dru Gladney specializes in the peoples, cultures and politics along the ancient and modern Silk Road—in particular, issues of globalization and transnationalism in China and its close neighbors. Over the last few years, he has engaged in a large comparative survey of nomadic families in Western China, bolstered by in-depth fieldwork with nomadic Kazakhs in the Altai Mountains bordering China and Mongolia.

\begin{abstract}
In this paper, I will argue that the continuing incidents of violence that have occurred in the region known as the Uyghur Autonomous Region of Xinjiang, or Eastern Turkestan, are best understood as incidents of civil unrest in the public sphere, and rarely can be described as "secessionism" (fenliezhuyi) in the traditional sense of the term (which I take to mean coordinated acts of violence against the government and civilian populations for the purpose of establishing an independent state). ${ }^{1}$ The struggles of the Uyghur people with the Chinese nation-state that have taken place since its incorporation in 1949 are best understood in the context of efforts to attain sovereignty, not as a religious or Islam-inspired campaign. Except for the fact that the Uyghur are a Muslim people, their concerns and issues resemble that of Tibet, and the occasional violence that takes place in the Tibetan Autonomous Region in China and protests against Chinese rule, are rarely if ever described as "terrorist," though they are often lumped together with the Uyghur incidents as "secessionist" (fenliezhuyi). At the same time, in this paper an attempt will be made to show that the region of Xinjiang, which had been extremely peaceful since the late 1990s, but then erupted in the last few years, has been caught up in an economic boom that would be the envy of any of its surrounding Central Asian states. Indeed, China should be congratulated for the enormous economic and social transformation of the region over the past two decades, but at the same time should be encouraged to find ways to preserve and promote the vibrant and extraordinary Central Asian civilization that Uyghur culture represents.
\end{abstract}

\section{Keywords}

Xinjiang Uyghur Autonomous Region, China, Uyghur, secessionism

\footnotetext{
${ }^{1}$ For the sake of coherence (cf. Introduction), we decided to translate fenliezhuyi as "secessionism" instead of "separatism". Although the Chinese translation of "secession" is tuoli, "tuolizhuyi" is never used and what the Chinese authorities derogatively qualify as fenliezhuyi can cover, on purpose and in order to dismiss them, both the movements that fight for independence and the ones that only demand a meaningful political autonomy.
} 


\section{Introduction}

By paying to attention to Uyghur engagement in the public sphere, especially domestically in the urban spaces of Urumqi and other Uyghur centers, such as Kashgar and Khotan, as well as examining further Uyghur participation in the virtual public sphere through new forms of social media and the internet, in this paper it will be argued that a new virtual community of Uyghur have begun to counter the hegemonic discourse of the Chinese state regarding to Uyghur unrest and aspirations in the region. Cites of contestation, it will be argued, have thus been translocated through these new forms of social media, leading to a re-territorialization of public space, not only virtually on the internet, but with real implications for actions on the ground. Arjun Appadurai ${ }^{2}$ seminally argued that "deterritorialization" is a prominent condition of modernity at large in the new public sphere, yet I am suggesting that we are witnessing the increasing role of the internet in re-terrioritializing homeland spaces lost to subject peoples, often displaced by authoritarian regimes. In an earlier articleb ${ }^{3}, \mathrm{I}$ argued that growing Uyghur "cyber-secessionism" and "cyber-separatism" did not really pose a threat to the Chinese state at that time as it was supported by a disembodied mix of competing international diasporic groups who had little chance of mounting any organized resistance which could possibly challenge Chinese sovereignty within Xinjiang. In his masterful survey, Yitzhak Shichor similarly argued that contradictions and competing agendas among the diaspora kept the Uyghur from forming a unified agenda ${ }^{4}$. However, given the dramatic rise in Uyghur connectivity and recent events in the Middle East among the various Arab Springs and Jasmine Revolutions of 2011, in this paper I shall argue that a new virtual Uyghur community has begun to emerge in the diaspora that has indeed given Beijing much greater cause for concern. In short, this paper suggests that cyber-separatism is becoming more than just virtual for the Uyghur diaspora, and not unlike events in the Middle East, has begun to have real impacts on the colonized space that was once known as Eastern Turkestan leading, indeed, to a possible future re-territorialization. To some extent then, Uyghur cybersecessionism/separatism could lead to the establishment of a virtual nation, but one that for

\footnotetext{
${ }^{2}$ APPADURAI, Arjun. "Disjuncture and Difference in the Global Cultural Economy," Public Culture 1990, 2.2:1-24, p. 2.

${ }^{3}$ GLADNEY, Dru C. Cyber-Separatism, Islam, and the State in China. In J. Craig Jenkins and Esther E. Gottlieb (eds.) Identity Conflicts: Can Violence be Regulated? New Brunswick: Transaction Publishers, 2007, pp. 95-97. ${ }^{4}$ SCHICHOR, Yitzhak. Virtual Transnationalism: Uyghur Communities in Europe and The Quest for East Turkestan Independence. Muslim Networks and Transnational Communities in and Across Europe, edited by S. Allievi and J. Nielsen, 281-311. Leiden: E. J. Brill, 2003, 283-284.
} 
the distant future will remain outside of China, virtually existing in the diaspora and on the internet.

\section{Rumblings from the West}

After nearly 10 years of relative peace in the Xinjiang Uyghur Autonomous Region, sporadic incidents of violence in 2008 presaged a huge urban uprising in Urumqi in 2009 that nearly overwhelmed local authorities, leading to the highest death toll from civil violence in the history of the People's Republic of China. ${ }^{5}$ Previously, in 1997, bombs exploded in a city park in Beijing on 13 May (killing one) and on two buses on 7 March (killing two), as well as in the northwestern border city of Urumqi, the capital of Xinjiang Uyghur Autonomous Region, on 25 February (killing 9), with over 30 other bombings in 1998, and six in Tibet that year as well. Most of these are thought to have been related to demands by Muslim and Tibetan secessionists. Numerous members of the Uyghur Muslim minority have been executed since those events of the late 1990s, with hundreds arrested on suspicion of taking part in ethnic riots and engaging in secessionist activities. Though sporadically reported since the early 1980s, such incidents were rather frequent in the late 1990s, and harsh treatment by suspects involved in those incidents was documented in a scathing report of Chinese government policy in the region by Amnesty International. ${ }^{6}$ As far as we know, these late 1990s incidents represent the only documented incidents of violence that appeared to be wellcoordinated, taking place at the same time across urban and national spaces. Nothing since has matched the level of sophistication or coordination of these late 1990s events. The Wall Street Journal ${ }^{7}$ reported the arrest on 11 August 1999 of Rebiya Kadeer, a well known Uyghur businesswoman once sent to represent the Xinjiang region to the International Women's Conference in Beijing (1995) during a visit by the United States Congressional Research Service delegation to the region, indicating China's strong response to these tensions. Amnesty International labeled Rebiya a "prisoner of conscience" as her only

\footnotetext{
${ }^{5}$ Estimates range from 140-1000+ deaths, two-thirds Han Chinese, which led to unprecedented coverage and criticism in the Chinese media. See "Xinjiang riot hits regional anti-terror nerve", Xinhua, 7 July 2009, http://news.xinhuanet.com/english/2009-07/18/content_11727782.htm; also Minxin Pei, "Uighur Riots show need for Re-think in Beijing" Financial Times, 9 July 2009; "China says 140 Die in Riot, Uighur Separatists Blamed" 6 July 2009, http://www.bloomberg.com/apps/news?pid=newsarchive\&sid=aBWP2E9DJPIU. An extensive report by the Uyghur Human Rights Project of the Uyghur American Association was released on July 5, 2011, "A city ruled by fear and silence: Urumchi, two years on" http://docs.uyghuramerican.org/July5report.pdf.

${ }^{6}$ Amnesty International. Peoples Republic of China: Gross Violations of Human Rights in the Xinjiang Uighur Autonomous Region. London, 21 April 1999.

${ }^{7}$ Wall Street Journal. Ian Johnson. "China Arrests Noted Businesswoman in Crackdown in Muslim Region". 18 August 1999.
} 
tangible offense was an unsuccessful attempt to meet with the USCRS. ${ }^{8}$ Her release to the US in 2005, and her active role in promoting a "World Uyghur Congress" has led to her assuming a prominent position among the Uyghur exile community both in the US and abroad and her being labeled as a "terrorist" and "secessionist" by the Chinese government. ${ }^{9}$ Her leadership has helped galvanize the Uyghur diaspora like never before, and lacking a Dalai Lama, some analysts have started referring to her as the "Dalai Mama" for the Uyghur diaspora. Skillful use of the public media and international news outlets have helped bring her message about the "plight" of her people to the greater public to an unprecedented degree.

It is important to note that the Uyghur protests and subsequent crackdowns of the 1990s and mid-2000s have rarely been connected to freedom of religion issues, but rather to a range of "indigenous rights" issues, of which religion is only one concern. Chinese officials argue that "splittists" (that is, secessionists) violate the law and that full freedom of religion is allowed under Article 36 of the constitution. ${ }^{10}$ An earlier White Paper on nationalities policy in China published just prior to the $50^{\text {th }}$ Anniversary of the PRC in October 1999, argued that religious freedom was guaranteed for all minorities, but acknowledged continuing problems in minority regions, especially vast economic inequities (China State Council 1999).

Despite on-going tensions and frequent reports of isolated terrorist acts, there has been no evidence that any of these actions have been aimed at disrupting the economic development of the region. Not a single documented incident has targeted infrastructure (railways, bridges, power stations, airports), which one would expect if there were a wellorganized terrorist or secessionist conspiracy. Most confirmed incidents have been directed against Han Chinese security forces, recent Han Chinese émigrés to the region, and even Uyghur Muslims perceived to be too closely collaborating with the Chinese government. Even those who claim that there is active Taliban and al-Qaida coordination of Uyghur violence in the region, have a hard time pointing to violent incidents that resemble al-Qaida

\footnotetext{
${ }^{8}$ Amnesty International. "China: Uighur businesswoman Rebiya Kadeer sentenced to eight years' after secret trial” News Service 47/00, AI INDEX: ASA 17/10/00, 10 March 2000.

${ }^{9}$ Although she has yet to be received by the Obama administration, Ms. Kadeer presented testimony on 10 June 2009 to the US Committee on Foreign Affairs, Congressional Subcommittee on International Organizations, Human Rights, and Oversight, entitled: "The Uyghurs: A History of Persecution" http://foreignaffairs.house.gov/111/kad061009.pdf

${ }^{10}$ Freedom of Religion law, Article 36 of the PRC Constitution: "Citizens of the People's Republic of China enjoy freedom of religious belief. No state organ, public organization or individual may compel citizens to believe in, or not to believe in, any religion; nor may they discriminate against citizens who believe in, or do not believe in, any religion. The state protects normal religious activities. No one may make use of religion to engage in activities that disrupt public order, impair the health of citizens or interfere with the educational system of the state. Religious bodies and religious affairs are not subject to any foreign domination".
} 
techniques, such as sophisticated weaponry, roadside bombs, or even suicide bombings. ${ }^{11}$ There has been no confirmed evidence of such violence in the Xinjiang region, with almost all incidents evidencing low-grade weaponry (knives, stones, public buses) and public security targets (police stations, checkpoints, etc.). Most analysts agree that China is not vulnerable to the same ethnic separatism that split the former Soviet Union. But few doubt that should China fall apart, it would divide, like the USSR, along centuries old ethnic, linguistic, regional, and cultural fault lines. If China did break apart, Xinjiang would split in a way that would resemble the conflicts experienced in neighboring regions like modern Kashmir, or the mid-1990s violent civil war of Tajikistan.

\section{Xinjiang: a "new region" rooted in the past}

Chinese histories notwithstanding, every Uyghur firmly believes that their ancestors were the indigenous people of the Tarim basin, which did not become known in Chinese as "Xinjiang" ("new dominion") until the eighteenth century. Nevertheless, the identity of the present people known as Uyghur is a rather recent phenomenon related to Great Game rivalries, SinoSoviet geopolitical maneuverings, and Chinese nation-building. While a collection of nomadic steppe peoples known as the "Uyghur" have existed since before the eighth century, this identity was lost from the fifteenth to the twentieth century. It is one of the world's least subtle ironies that Chinese histories resolutely assert the long-term dominance of the region by Chinese rulers, yet continue to officially promote the term "Xinjiang" ("New Region") as the territory's appellation. This irony is certainly not lost on the Uyghurs, who continue to regard themselves as an internal colony of China, and a rather recent one at that. ${ }^{12}$

The idea of a Uyghur nation, and as an independent state that has roots back to the $7^{\text {th }}$ century Uyghur empire, has been further aided by the internet which regularly refers to this romanticized, territorialized past. ${ }^{13}$ The Uyghur culture and its people's genetic make-up, reflect the fact that they migrated from an area that is now in Mongolia to the region now

\footnotetext{
${ }^{11}$ Rohan Gunaratna, as cited in "Xinjiang riot hits regional anti-terror nerve". Xinhua. China Daily. 2009-07-18. http://www.chinadaily.com.cn/china/2009-07/18/content_8445811.htm. Although Gunaratna, a self-styled terrorism expert with no research experience in China, has claimed direct links between ETIM and al-Qaida, he has yet to offer independent confirmation that the group is still active, or that any of the violence in Xinjiang is connected to global jihadism, other than Chinese sources (see Rohan Gunaratna, 2002. Inside Al Qaeda: Global Network of Terror. New York: Columbia University Press).

${ }^{12}$ GLADNEY, Dru C. Internal Colonialism and China's Uyghur Muslim Minority. International Institute for the Study of Islam in the Modern World Newsletter. October, 1: 20-21, 1998 (d).

http://isim.leidenuniv.nl/newsletter/1/regional/01AC23.html

${ }^{13}$ One of the best examples of this is the website maintained by the ethnomusicologist, Dr. Nathan Light, http://homepages.utoledo.edu/nlight/uyghpg.htm
} 
known as Xinjiang or Eastern Turkistan. The region had always been at the center of a "civilizational cross-roads", involving long-distance travel and inter-mixing by speakers of Iranian, Indian, Chinese, Tibetan, Turkic, Mongolian, and even European tongues. Until their rather belated conversion to Islam (compared to the rather rapid conversion of other Central Asian peoples), the Uyghurs were shamanists, Buddhists, Manichaeans, and even Nestorian Christians. The Uyghur-dominated oases of the region, due to their superior agricultural and mercantile economies, were frequently over-run by nomadic powers from the steppes of Mongolia and Central Asia, and even intermittently, Chinese dynasties who showed interest in controlling the lucrative trade routes across Eurasia. According to Morris Rossabi, it was not until 1760, and after their defeat of the Mongolian Zungars, that the Manchu Qing dynasty exerted full and formal control over the region, establishing it as their "new dominions" (Xinjiang), an administration that had lasted barely 100 years, when it fell to the Yakub Beg rebellion (1864-1877) and expanding Russian influence. ${ }^{14}$ Until major migrations of Han Chinese was encouraged in the mid-nineteenth century, the Qing were mainly interested in pacifying the region by setting up military outposts which supported a vassal-state relationship. Colonization had begun with the migrations of the Han in the mid-nineteenth century, but was cut short by the Yakub Beg rebellion, the fall of the Qing Empire in 1911, and the ensuing warlord era which dismembered the region until its incorporation as part of the People's Republic in 1949. Competition for the loyalties of the peoples of the oases in the Great Game played between China, Russia and Britain further contributed to divisions among the Uyghur according to political, religious, and military lines. The peoples of the oases in this region, until the challenge of nation-state incorporation, lacked any coherent sense of identity.

Thus, the incorporation of Xinjiang for the first time into a nation-state required unprecedented delineation of the so-called nations involved. Before its recent re-emergence, the label "Uyghur" was last time used 500 years ago to describe the largely Buddhist population of the Turfan Basin. In spite of this, this label has been in use in the last 80 years as the appellation for the settled Turkic-speaking Muslim oasis dwellers. Its use has never been disputed by the people themselves or the states involved. There is too much at stake for the people labeled as such to wish to challenge that identification. For Uyghur nationalists

\footnotetext{
${ }^{14}$ ROSSABI, Morris. "Muslim and Central Asian Revolts" in Jonathan D. Spence \& John E. Wills Jr. eds. From Ming to Ch'ing. New Haven: Yale University Press, 1979.
} 
today, the direct lineal descent from the Uyghur Kingdom in seventh century Mongolia is accepted as fact, despite overwhelming historical and archeological evidence to the contrary. ${ }^{15}$

The end of the Qing dynasty and the rise of Great Game rivalries between China, Russia, and Britain saw the region torn by competing loyalties and marked by two short-lived and drastically different attempts at independence: the proclamations of an "East Turkestan Republic" in Kashgar in 1933 and another in Yining (Ghulje) in $1944 .{ }^{16}$ As Linda Benson ${ }^{17}$ has extensively documented, these rebellions and attempts at self-rule did little to bridge competing political, religious, and regional differences within the Turkic Muslim people who became officially known as the Uyghur in 1934 under successive Chinese Kuomintang (KMT) warlord administrations. Andrew Forbes ${ }^{18}$ describes, in exhaustive detail, the great ethnic, religious, and political cleavages during the period from 1911 to 1949 that pitted Muslim against Chinese, Muslim against Muslim, Uyghur against Uyghur, Hui against Uyghur, Uyghur against Kazak, warlord against commoner, and Nationalist against Communist. There was short-lived independent Uyghur rule during two important periods, which Uyghur today claim provide indisputable evidence of self-governance and even secular-inspired democratic rule. Uyghurs, Uzbeks, and other Central Asian Turkic peoples formed an "Eastern Turkestan Republic" (ETR) in Kashgar for less than a year in 1933, that was inspired by religious, Islamic ideals.

A decade later, the Soviet Union supported another attempt at independent Uyghur rule, establishing a more secular nationalist state, another "Eastern Turkestan Republic" in the northern part of Xinjiang, around the town now known as Yining (where there was a Russian consulate in recognition of this newly formed nation-state). During 1944-45, the ETR fought against the Chinese Nationalists (KMT) who were holding southern Xinjiang. Due to a wartime alliance between the KMT and the Soviets, the Russian eventually pressured the ETR to cooperate with the Chinese, and they formed an uneasy alliance, until the Chinese communists defeated the KMT and occupied the region in 1949, in what they described as a "peaceful liberation" (due to Sino-Soviet cooperation at that time). Uyghur nationalists then

\footnotetext{
${ }^{15}$ The best "Uighur nationalist" retelling of this unbroken descent from Karakhorum is in the document from the Eastern Turkestani Union in Europe (cf. references). For a review and critique, including historical evidence for the multi-ethnic background of the contemporary Uighur, see Gladney 1998c; for a discussion of the recent archeological evidence derived from DNA dating of the desiccated corpses of Xinjiang, see Mair 1998.

${ }^{16}$ The best discussion of the politics and importance of Xinjiang during this period is that of an eyewitness and participant, Owen Lattimore (Lattimore 1950).

${ }^{17}$ BENSON, Linda. The Ili Rebellion: The Moslem Challenge to Chinese Authority in Xinjiang, 1944-1949. New York: M.E. Sharpe, 1990.

${ }^{18}$ FORBES, Andrew. Warlords and Muslims in Chinese Central Asia. Cambridge: Cambridge University Press, 1986.
} 
had hoped to achieve a semi-independent Republic along the Soviet lines of Uzbekistan and Kazakstan, but they had to settle for recognition as a Chinese "minority nationality" with an Autonomous Region of Xinjiang (with much less juridical authority than the Soviet "union republics"). The extraordinary factionalism and civil disunion during this period which caused large scale depletion of lives and resources in the region, still lives in the minds of the population. Indeed, it is this memory that many argue keeps the region together, a deep-seated fear of widespread social disorder. ${ }^{19}$

Today, despite continued regional differences among three, and perhaps four macroregions, including the northwestern Zungaria plateau, the southern Tarim basin, the southwest Pamir region, and the eastern Kumul-Turpan-Hami corridor, there are nearly 10 million people spread throughout this vast region that regard themselves as Uyghur, among a total population of 17 million $^{20}$. Many of them dream of, and some agitate for, an independent "Uyghuristan". The "nationality" policy under the KMT identified five peoples of China, with the Han in the majority. The Uyghur were included at that time under the general rubric of "Hui Muslims", which then included all Muslim groups in China. This policy was continued under the Communists, eventually recognizing 56 nationalities, the Uyghur and 8 other Muslim groups split out from the general category "Hui" (which was confined to mainly Chinese-speaking Muslims).

The separate nationality designation awarded to the Uyghurs in China continued to mask very considerable regional and linguistic diversity, with the designation also applied to many "non-Uyghur" groups such as the Loplyk and Dolans, that had very little to do with the oasis-based Turkic Muslims that became known as the Uyghur. At the same time, contemporary Uyghur secessionists look back to the brief periods of independent self-rule under Yakub Beg and the Eastern Turkestan Republics, in addition to the earlier glories of the Uyghur kingdoms in Turpan and Karabalghasan, as evidence of their rightful claims to the region. Contemporary Uyghur secessioniost organizations based in Istanbul, Ankara, Almaty, Munich, Amsterdam, Melbourne, and Washington may differ in their political goals and strategies for the region, but they all share a common vision of a continuous Uyghur claim on the region, disrupted by Chinese and Soviet intervention. The independence of the former Soviet Central Asian Republics in 1991 has done much to encourage these Uyghur

\footnotetext{
${ }^{19}$ James Millward's history is the best overview of this tumultuous period (Milward 2007).

${ }^{20}$ RUDELSON, Justin Jon. Oasis Identities: Uighur Nationalism along China's Silk Road. New York: Columbia University Press, 1998.

CHEN, Jack. The Sinkiang Story. New York: Macmillan, 1977.

GLADNEY, Dru C. The ethnogenesis of the Uighur. Central Asian Survey, 1990, 9.1: 1-28.
} 
organizations in their hopes for an independent "Uyghuristan", despite the fact that the new, mainly Muslim, Central Asian governments all signed protocols with China in Shanghai in the Spring of 1996 that they would not harbor or support secessionist groups. These protocols were reaffirmed in the 25 August 1999 meeting between Boris Yeltsin and Jiang Zemin, committing the "Shanghai Five" nations (China, Russia, Kazakstan, Kyrgyzstan, Tajikistan) to respecting border security and suppressing terrorism, drug smuggling, and secessionism. ${ }^{21}$ The policy was enforced on 15 June 1999, when three alleged Uyghur secessionists (Hammit Muhammed, Ilyan Zurdin, Khasim Makpur) were deported from Kazakhstan to China, with several others in Kyrgyzstan and Kazakhstan awaiting extradition. ${ }^{22}$ The Shanghai Cooperation Organization (SCO) has evolved from what was originally a trade and border settlement alliance to become an increasingly powerful multi-lateral organization with a strong focus on anti-terrorism security cooperation.

That Islam became an important, but not exclusive, cultural marker of Uyghur identity is not surprising given the socio-political oppositions with which the Uyghur were confronted. In terms of religion, the Uyghurs are Sunni Muslims, practicing Islamic traditions similar to their co-religionists in the region. In addition, many of them are Sufi, adhering to branches of Naqshbandiyya Central Asian Sufism. Uyghur's are powerfully attached to their musical traditions, colorful dress, and patronage of saintly tomb complexes (mazar). ${ }^{23}$ These practices are anathema to the strict Wahhabi-inspired Islamist codes of the Taliban and al-Qaida who severely persecute many Sufi's and folk artists.

However, it is also important to note that Islam was only one of several unifying markers for Uyghur identity, depending on those with whom they cooperating at the time. This suggests that Islamic fundamentalist groups such as the Taliban in Afghanistan will have only limited appeal among the Uyghur. For example, to the Hui Muslim Chinese in Xinjiang, numbering over 600,000 , the Uyghur distinguish themselves as the legitimate autochthonous minority, since both share a belief in Sunni Islam. In contrast to the formerly nomadic Muslim peoples, such as the Kazakh, numbering more than one million, the Uyghur might stress their attachment to the land and oasis of origin. Most profoundly, modern Uyghurs, especially those living in larger towns and urban areas, are marked by their reaction to Chinese influence

\footnotetext{
${ }^{21}$ CNN News Service. Rym Brahimi. "Russia, China, and Central Asian Leaders Pledge to Fight Terrorism, Drug Smuggling” 25 August 1999, www.uygur.org/enorg/wunn99/990825e.html

${ }^{22}$ Eastern Turkistan Information Center. "Kasakistan Government Deport Political Refugees to China". Munich, 15 June 1999. www.uygur.org/enorg/reports99/990615.html

${ }^{23}$ See the important article by Rahile Dawut a Uyghur female ethno-historian on Uyghur tomb complexes and grave veneration with beautiful color photograph. (Dawut 2009: 56-67).

(http://www.silkroadfoundation.org/newsletter/vol6num2/srjournal_v6n2.pdf)
} 
and incorporation. It is often Islamic traditions that become the focal point for Uyghur efforts to preserve their culture and history. One such popular tradition that has resurfaced in recent years is that of the Mashrap, where generally young Uyghurs gather to recite poetry and sing songs (often of folk or religious content), dance, and share traditional foods. These evening events have often become foci for Uyghur resistance to Chinese rule in past years. However, although within the region many portray the Uyghur as united around secessionist or Islamist causes, Uyghur continue to be divided from within by religious conflicts, in this case competing Sufi and non-Sufi factions, territorial loyalties (whether they be oases or places of origin), linguistic discrepancies, commoner-elite alienation, and competing political loyalties. These divided loyalties were evidenced by the attack in May 1996 on the Imam of the Idgah Mosque in Kashgar by other Uyghurs, as well as the assassination of at least six Uyghur officials in September 1997. It is this contested understanding of history that continues to influence much of the current debate over secessionist and Chinese claims to the region. That many of these divided loyalties are beginning to be overcome in the diaspora marks an important development in global Uyghur identity. As Kristian Petersen ${ }^{24}$ has noted, the internet has played an increasingly important role in uniting Uyghur sectarianism and factionalism.

\section{Han nationalism and the Uyghur}

The Uyghur are an official minority nationality of China, identified as the second largest of ten Muslim peoples in China, primarily inhabiting the Xinjiang Uyghur Autonomous Region. Many Uyghur with whom I have spoken in Turfan and Kashgar argue persuasively that they are the autochthonous people of this region. The fact that over 99.8 per cent of the Uyghur population are located in Xinjiang, whereas other Muslim peoples of China have significant populations in other provinces (e.g. the Hui) and outside the country (e.g. the Kazak), contributes to this important sense of belonging to the land. The Uyghur continue to conceive of their ancestors as originating in Xinjiang, claiming to outsiders that "it is our land, our territory", despite the fact that the early Uyghur kingdom was based in what is now Outer Mongolia and the present region of Xinjiang is under the control of the Chinese State.

Unprecedented socio-political integration of Xinjiang into the Chinese nation-state has taken place in the last 60 years. While Xinjiang has been under Chinese political domination

\footnotetext{
${ }^{24}$ PETERSEN, Kristian. "Usurping the Nation: Cyber-Leadership in the Uighur Nationalist Movement" Journal of Muslim Minority Affairs 2006, 26 (1), p. 66.
} 
since the defeat of the Zungar in 1754, until the middle of the twentieth century it was but loosely incorporated into China proper. The extent of the incorporation of the Xinjiang Region into China is indicated by Chinese policies encouraging Han migration, communication, education, and occupational shifts since the 1940s. Han migration into Xinjiang increased their local population a massive 2,500 per cent between 1940 and 1982, representing an average annual growth of 8.1 per cent, and have maintained an average growth of nearly 5 percent ever since, with a current population of nearly 45 percent. Indeed, many conclude that China's primary programme for assimilating its border regions is a policy of integration through immigration. ${ }^{25}$ This was certainly the case for Inner Mongolia, where Mongol population now stands at a mere 17 (rather than 12, according to more recent data) per cent, and given the following figures may well be the case for Xinjiang. The former Party Secretary of Xinjiang from 1994-2010, Wang Lequan, also known as the "stability secretary" for his role in ruthlessly suppressing dissent and fervently executing Beijing's "strike hard campaign", masterminded the unparalleled flooding of Xinjiang with Han migrants from the interior. A native and former vice-governor of Shandong province, many suspect Chairman Wang lost his position as Party Secretary of Xinjiang for his poor handling of the July 2009 riots, although he retained his position in the central Politbyro of the CCP (elevated in $2004) .^{26}$

\section{Meager Uyghur efforts at cultural survival}

Integration with China has not been smooth for the Uyghur. Many Uyghur resent the threats to their cultural survival and have resorted to violence. After denying the existence of conflicts for decades and stressing instead China's "national unity", official reports have detailed Tibetan and Muslim conflict activities in the border regions of Tibet, Yunnan, Xinjiang, Ningxia, and Inner Mongolia. With the March 1997 bus bombings in Beijing, widely attributed (though this has never been verified) to Uyghur secessionists, coupled with the Urumqi bus bombings on the day of Deng Xiaoping's 1997 memorial on 25 February, Beijing can no longer keep them secret. The Yining uprising on 7 February 1997, which left at least nine dead and hundreds injured, with seven Uyghur suspects arrested and most probably slated for execution, was widely covered by the world's media. This distinguishes

\footnotetext{
${ }^{25}$ For China's minority integration program, see Mackerras 1994.

${ }^{26}$ Edward Wong and Jonathan Ansfield, "China Replaces Leader of the Restive Xinjiang Region" The New York Times May 15, 2010: A10; Michael Wines, “A Strongman is China's Rock in Ethnic Strife” The New York Times July 10, 2009: A11; Gladney 2004: 378-85.
} 
these last few events from on-going problems in the region in the mid-1980s that met with little media coverage. In 1996, the Xinjiang Daily reported five serious incidents since February 1996, with a crackdown that rounded up 2,773 terrorist suspects, 6,000 lbs of explosives, and 31,000 rounds of ammunition. Overseas Uyghur groups have claimed that over 10,000 were arrested in the round-up, with over 1,000 killed. The largest protest which took place from 2 to 8 February 1996, was sparked by a Chinese raid on an evening Mashrap cultural meeting. Protests against the arrests made during the meeting led to 120 deaths and over 2,500 arrests. On 2 March 1996 the pro-government mullah of Kashgar's Idgah mosque and his son were stabbed by knife-wielding Uyghur militants, on 27 May there was another attack on a senior government official, and in September of the same year six Uyghur government officials were killed by other Uyghurs in Yecheng.

The government responded severely in the late 1990s with a widespread arrests and new policy announcements. In Spring 1998, the National People's Congress passed a New Criminal Law that redefined "counter-revolutionary" crimes to be "crimes against the state", liable to severe prison terms and even execution. Included in "crimes against the state" were any actions considered to involve "ethnic discrimination" or "stirring up anti-ethnic sentiment". Many human rights activists have argued that this is a thinly veiled attempt to criminalize "political" actions and to make them appear as illegal as traffic violations, supporting China's claims that it holds "no political prisoners". Since any minority activity could be regarded as stirring "anti-ethnic feeling", many ethnic activists are concerned that the New Criminal Law will be easily turned against them.

Chinese authorities are correct that increasing international attention to the plight of indigenous border peoples have put pressure on the regions. Notably, the formerly elected chair of the Unrepresented Nations and People's Organization (UNPO) based in the Hague was the Uyghur, Erkin Alptekin, son of the Uyghur nationalist leader, Isa Yusuf Alptekin, who died in Istanbul in December 1995 where there is now a park dedicated to his memory. There are numerous international organizations working for the independence of Xinjiang [under the name of Eastern Turkestan], based in Amsterdam, Munich, Istanbul, Melbourne, Washington DC, and New York. An organization that seeks to coordinate these disparate movements is the World Uyghur Congress, formed in 2004 with Erkin Alptekin as President. In its Washington, DC, meeting from May 21-25, 2006, the Congress elected Madam Rebiya 
Kadeer as President (http://www.uighurcongress.org). Although, as Chung ${ }^{27}$ has noted, the WUC is merely an umbrella organization uniting for the first time a large number of disparate Uyghur diaspora organizations in a democratic format, the Chinese government has nevertheless labeled the WUC as a "terrorist organization" (Mackerras 2007: 101). The official position of the WUC, which is growing in influence among Uyghur communities and organizations across the globe, is to push for real autonomy and not demand independence or secession at this time, along the same lines as the Tibetan Government in Exile. ${ }^{28}$

Clearly, since Xinjiang is the last Muslim region under communism, the international support for the WUC and Uyghur independence is of more concern to Chinese authorities than is the international support for Tibetan independence.

The important question is: why do the Chinese authorities call such attention to these Tibetan and Muslim activities and external organizations? From 1998 to 2008, there was a decade without a single incident of Uyghur-related violence. The Istanbul-based groups have existed since the 1950s, and the Dalai Lama has been active since his exile in 1959. Secessionist actions have taken place on a small but regular basis since the expansion of market and trade policies in China, and with the opening of overland gateways to Xinjiang in addition to the trans-Eurasian railway since 1991, there seems to be no chance of closing up shop. In his 1994 visit to the newly independent nations of Central Asia, Li Peng called for the opening of a "new Silk Road". This was a clear attempt to calm fears in the newly established Central Asian states over Chinese expansionism, as was the April 1996 Shanghai communiqué that solidified the existing Sino-Central Asian borders. Documented separatist and violent incidents in Xinjiang had dropped off dramatically since the late 1990s. In July 14, 2002 Washington Post (2002) interview Philip Pan reported that local Xinjiang security officials were only able to cite three relatively small occurrences. Beijing's official publication of the secessionist issue may have more to do with domestic politics than any real internal or external threat. Recent moves such as evidenced in the 2008 Olympics suggest efforts to promote Chinese nationalism as a "unifying ideology" that will prove more attractive than communism and more manageable than capitalism. By highlighting secessionist threats and external intervention, China can divert attention away from its own

\footnotetext{
${ }^{27}$ Chung, Chien-peng. "Confronting Terrorism and Other Evils in China: All Quiet on the Western Front?' China and Eurasia Forum Quarterly. 2006, 4(2), 75-87.

${ }^{28}$ See the position of the World Uyghur Congress at http://www.uyghurcongress.org/en/?cat=1. The Globalsecurity.org report on "Uyghur militants" states unequivocally that with regard to the World Uyghur Congress, it is "a nonviolent and peaceful opposition movement against Chinese occupation of East Turkestan..." with an "unconditional rejection of totalitarianism, religious intolerance and terrorism as an instrument of policy" (http://www.globalsecurity.org/military/world/para/uighur.htm).
} 
domestic challenges of natural disasters (especially the 2008 Sichuan earthquake), economic crises (such as the Asian economic downturn's drag on China's currency), rising inflation, increased income disparity, displaced "floating populations", Taiwan reunification, and the many other internal and external problems facing the Chinese Communist Party leadership. Perhaps nationalism will be the only "unifying ideology" left to a Chinese nation that has begun to distance itself from Communism, as it has from Confucianism, Buddhism, and Daoism in the past. This is perhaps why religiously-based nationalisms, like Islamic fundamentalism and Tibetan Buddhism, are targeted by Beijing, while the rise of shamanism and popular religion goes nearly unchecked. At the same time, a firm lid on Muslim activism in China sends a message to foreign Muslim militant organizations to stay out of China's internal affairs, and the Taliban to stay well within their Afghan borders. Although it is hard to gauge the extent of support for Uyghur secessionism and separatism among the broader population, it is clear that cultural survival is a critical concern for many, and a significant attempt to preserve Uyghur culture is taking place, assisted to some extent by international tourism and the state's attempts to demonstrate its goodwill toward its restive Muslim population.

\section{Territorializing the Uyghur future}

To an extent never seen before, the continued incorporation of Xinjiang into China has become inexorable, and perhaps irreversible. The need for the oil and mineral resources of the region since China became an oil importing nation in 1993 means that Chinese influence will only grow. To be sure, the Uyghur are still oriented culturally and historically toward Central Asia in terms of religion, language, and ethnic custom, and interaction has increased in recent years due to the opening of the roads to Pakistan and Almaty. China has also recently discussed opening the border between Afghanistan and Xinjiang via the ancient Wakhan Corridor, where there is no road but only an ancient donkey trail used since Silk Road days. ${ }^{29}$ Certainly, pan-Turkism was appealing to some, but not all, Uyghurs during the early part of this century. Historical ties to Central Asia are strong. Turkey's late Prime Minister Turgut Ozal espoused a popular Turkish belief when, on his first state visit to Beijing in 1985, which sought to open a consulate there, he commented that the Turkish nation originated in what is now China. Yet separatist notions, given the current political incorporation of Xinjiang into

\footnotetext{
${ }^{29}$ See the Stratfor paper documenting the Afghan Prime Minister's request for China to open the Wakhan corridor, June 11, 2009, "China: Afghan FM Seeks Wakhan Corridor Supply Route",

http://www.stratfor.com/sitrep/20090611_china_afghan_fm_seeks_wakhan_corridor_supply_route
} 
China, while perhaps present, are not practicable. They remain visions of a virtual community, but a community that is nevertheless becoming better organized and more audible in its message broadcast to those inside and outside of China. In his prescient article, Dale Eickelman ${ }^{30}$ noted that the new social media were beginning to transform the heretofore isolated authoritarian and reform-resistant regimes of the Middle East. Why should China be immune to these global trends? As noted above, much of what is written about China is predicated on the assumption that China as a nation holds together. But, if China should fail at the centre, or the Great Wall of information-control should be breached, the peripheries will certainly destabilize, with Xinjiang and Tibet having the strongest prospects for secession given their cultural unity and attempts at government-in-exile, as substantially augmented by the networking and community-building power of the internet and social networks.

The problems facing Xinjiang, however, are much greater than those of Tibet if it were to become independent. Not only is Xinjiang more integrated into the rest of China, but the Uyghur part of the population is less than half of the total and primarily located in the south, where there is less industry and natural resources, except for oil. As noted above, however, unless significant investment is found, Tarim oil and energy resources will never be a viable source of independent wealth. Poor past relations between the three main Muslim groups, Uyghur, Kazakh, and Hui, suggest that conflicts among Muslims would be as great as those between Muslims and Han Chinese. Most local residents believe that independence would lead to significant conflicts between these groups, along ethnic, religious, urban-rural, and territorial lines. Given the harsh climate and poor resources in the region, those caught in the middle would have few places to flee. Xinjiang Han would naturally seek to return to the interior of China, since Russia and Mongolia would be in no position to receive them. Yet given the premise that only a complete collapse of the state could precipitate a viable independence movement and internal civil war in Xinjiang, there would be few places the Han would be able to go. Certainly, the bordering provinces of Gansu and Qinghai would be just as disrupted, and Tibet would not be an option. Uyghur refugees would most likely seek to move south, since the north would be dominated by the Han and the western routes would be closed off by Kazakhstan and Kyrgyzstan. That leaves only the southern routes, and with the exception of Pakistan, no nation in the region would probably be equipped to receive them. Certainly, they would not be better off in present-day Tajikistan and Afghanistan.

\footnotetext{
${ }^{30}$ EICKELMAN, Dale F. 2. New Media in the Arab Middle East and the Emergence of Open Societies. In: Remaking Muslim Politics. Princeton University Press, 2009. p. 37-59.
} 
Given the on-going conflicts in Kashmir, even Pakistan, the most likely recipient of Uyghur refugees, would probably not wish further destabilization of the region. Note also that the main southern route to India and Pakistan, along the Karakhorum highway through the Torghurat pass, is generally passable less than six months out of the year. India, despite its poor relations with China, would probably not want to add to its Muslim population. During many conversations in Xinjiang with local residents, Muslim and Han alike, it became clear that this is a well-known fact. Most think that in such a worst-case scenario, there would be nothing to do but stay and fight.

In terms of religious freedom, as with many other policies, the Chinese constitution is laudable when honored. However, in a country where the rule of law often gives way to local and national politics, it is often only honored in the breech. As long as religion is perceived by Chinese officials as a threat to Chinese sovereignty, mosques and religious practice will be closely monitored and in some cases restricted. In light of international Islamic interest, however, Chinese officials have to be careful regarding any oppressive treatment of religious practice - especially if casting it as "splittist" or seditious, as in the February 1997 incident in Ili.

The history of Chinese-Muslim relations in Xinjiang, as Millward's (2007) book documented, has been one of relative peace and quiet, broken by enormous social and political disruptions, fostered by both internal and external crises. The opposition to Chinese rule in Xinjiang has not reached the level of Syria, Yemen, Chechnya or the Intifada, but similar to the Basque separatists of the ETA in Spain, or former IRA in Ireland and England, it is one that may erupt in limited, violent moments of terror and resistance. And just as these conflicts have not been resolved in the Middle East, North Africa, or Europe, the Uyghur problem in Xinjiang does not appear to be one that will readily go away. Nor are Uyghur in the diaspora able to engage with the region and participate regularly in its reform or development. To paraphrase Sean Roberts, unlike many Middle Easterners who regularly visit their homelands, Uyghur who are "waiting for Uyghuristan" must do their waiting and imagining on the internet, as expatriots are not allowed to visit the region. The admitted problem of Uyghur terrorism and dissent, even in the diaspora, is thus problematic for a government that wants to encourage integration and development in a region where the majority population are not only ethnically different, but also devoutly Muslim. How does a government integrate a strongly religious minority (be it Muslim, Tibetan, Christian, or Buddhist) into a "market-Leninist" system? China's policy of intolerance toward dissent and 
economic stimulus has not seemed to have resolved this issue. Given events on the western end of the Eurasian continent, China should find ways to open dialogue with representative Uyghur individuals and groups to better cooperate in finding solutions to this on-going problem. There has been much progress and relatively peaceful development of this important region. Surely a dialogue can be opened up in order to help insure a more prosperous and peaceful future, for both Uyghur and Han alike. 


\section{References}

Amnesty International. Peoples Republic of China: Gross Violations of Human Rights in the Xinjiang Uighur Autonomous Region. London, 21 April 1999.

Amnesty International. "China: Uighur businesswoman Rebiya Kadeer sentenced to eight years' after secret trial” News Service 47/00, AI INDEX: ASA 17/10/00, 10 March 2000.

APPADURAI, Arjun. "Disjuncture and Difference in the Global Cultural Economy," Public Culture 1990, 2.2:1-24.

BANISTER, Judith. China's Changing Population. Stanford: Stanford University Press, 1987.

BENSON, Linda. The Ili Rebellion: The Moslem Challenge to Chinese Authority in Xinjiang, 1944-1949. New York: M.E. Sharpe, 1990.

China State Council. "National Minorities Policy and its Practice in China", Beijing, Information Office of the State Council of the People's Republic of China, September 1999.

CNN News Service. Rym Brahimi. "Russia, China, and Central Asian Leaders Pledge to Fight Terrorism, Drug Smuggling” 25 August 1999, www.uygur.org/enorg/wunn99/990825e.html

CHEN, Jack. The Sinkiang Story. New York: Macmillan, 1977.

CHUNG, Chien-peng. "Confronting Terrorism and Other Evils in China: All Quiet on the Western Front?" China and Eurasia Forum Quarterly. 2006, 4(2), 75-87.

DAWUT, Rahile. Shrine Pilgrimage among the Uighurs. The Silk Road Journal, Winter/Spring 2009 (6) 2: 56-67.

http://www.silkroadfoundation.org/newsletter/vol6num2/srjournal_v6n2.pdf

DORIAN, James P.; WIGDORTZ, Brett; GLADNEY, Dru. Central Asia and Xinjiang, China: Emerging energy, economic and ethnic relations. Central Asian Survey, 1997, 16.4: 461-486.

Eastern Turkistan Information Center. "Kasakistan Government Deport Political Refugees to China". Munich, 15 June 1999. www.uygur.org/enorg/reports99/990615.html

Eastern Turkistan Information Center. "Population of Eastern Turkistan: The Population in Local Records". Munich, n.d. www.uygur.org/enorg/turkistan/nopus.html

Eastern Turkestani Union in Europe. "Brief History of the Uyghers". N. d. www.geocities.com/CapitolHill/1730/buh.html

EICKELMAN, Dale F. 2. New Media in the Arab Middle East and the Emergence of Open Societies. In: Remaking Muslim Politics. Princeton University Press, 2009. p. 37-59.

FORBES, Andrew. Warlords and Muslims in Chinese Central Asia. Cambridge: Cambridge University Press, 1986.

FRANKE, Herbert \& TWITCHETT, Denis. Cambridge History of China: Volume 6: Alien Regimes and Border States (907-1368). Cambridge: Cambridge University Press, 1994.

GLADNEY, Dru C. The ethnogenesis of the Uighur. Central Asian Survey, 1990, 9.1: 1-28.

GLADNEY, Dru C. Muslim Chinese: Ethnic Nationalism in the People's Republic of China. 2 ed., Cambridge MA: Harvard University Press, 1996.

GLADNEY, Dru C. Ethnic Identity in China. Fort Worth: Harcourt Brace, 1998 (a).

GLADNEY, Dru C. ed. Making Majorities: Constituting the Nation in Japan, Korea, China, Malaysia, Fiji, Turkey, and the United States. Stanford: Stanford University Press, 1998 (b). 
GLADNEY, Dru C. Ethnogenesis and Ethnic Identity in China: Considering the Uygurs and Kazakhs. In Victor Mair (ed.) The Bronze Age and Early Iron Age People of Eastern Central Asia: Volume II. Washington DC: Institute for the Study of Man, 1998 (c), pp. 812-34.

GLADNEY, Dru C. Internal Colonialism and China's Uyghur Muslim Minority. International Institute for the Study of Islam in the Modern World Newsletter. October, 1: 20-21, 1998 (d). http://isim.leidenuniv.nl/newsletter/1/regional/01AC23.html

GLADNEY, Dru C. "Making Muslims in China: Education, Islamicization, and Representation" in Gerard A. Postiglione, ed. China's National Minority Education: Culture, State Schooling and Development._New York: Garland Press, 1999.

GLADNEY, Dru C. Dislocating China: Muslims, Minorities, and Other Subaltern Subjects. Chicago: University of Chicago Press, 2004.

GLADNEY, Dru C. Cyber-Separatism, Islam, and the State in China. In J. Craig Jenkins and Esther E. Gottlieb (eds.) Identity Conflicts: Can Violence be Regulated? New Brunswick: Transaction Publishers, 2007, pp. 95-97.

International Taklamakan Human Rights Association (ITHRA). "How Has the Population Distribution Changed in Eastern Turkestan since 1949”. N.d. www.taklamakan.org/uighur-L/et_faq pl.html

LATTIMORE, Owen. Pivot of Asia: Sinkiang and the Inner Asian Frontiers of China and Russia. Boston: Little, Brown, 1950.

MACKERRAS, Colin. China's Minorities: Integration and Modernization in the Twentieth Century. Hong Kong: Oxford University Press, 1994.

MAIR, Victor. "Introduction" in Victor Mair ed. The Bronze Age and Early Iron Age People of Eastern Central Asia: Volume II. Washington DC: Institute for the Study of Man, 1998, pp. 1-40.

MILLWARD, James A. Eurasian Crossroads: A History of Xinjiang. New York: Columbia University Press, 2007.

MOSELEY, George. The Party and the National Question in China._Cambridge MA: MIT Press, 1966.

People's Republic of China. National Population Census Office. Population Atlas of China. Hong Kong: Oxford University Press, 1987.

People's Republic of China. National Population Census Office. Major Figures of the Fourth National Population Census: Vol. 4. Beijing: China Statistical Publishing House, 1991.

People's Republic of China. Department of Population Statistics of State Statistical Bureau and Economic Department of State Nationalities Affairs Commission. Population of China's Nationality (Data of 1990 Population Census) [Zhongguo Minzu Renkou Ziliao (1990 nian Renkou Pucha Shuju)]. Beijing: China Statistical Publishing House, 1994.

PETERSEN, Kristian. "Usurping the Nation: Cyber-Leadership in the Uighur Nationalist Movement" Journal of Muslim Minority Affairs 2006, 26 (1): 63-73.

Renmin Ribao [Beijing]. "Guanyu 1990 nian renkou pucha zhuyao de gongbao [Report regarding the 1990 population census primary statistics]". 14 November 1991.

ROBERTS, Sean R. Waiting for Uighurstan. Los Angeles: University of Southern California, Center for Visual Anthropology (video documentary), 1996.

ROSSABI, Morris. "Muslim and Central Asian Revolts" in Jonathan D. Spence \& John E. Wills Jr. eds. From Ming to Ch'ing. New Haven: Yale University Press, 1979.

RUDELSON, Justin Jon. Oasis Identities: Uighur Nationalism along China's Silk Road. New York: Columbia University Press, 1998.

MACKERRAS, Colin. "Xinjiang and the War against Terror." In Simon Shen ed. China and Antiterrorism. New York: Nova Science Publishers, 2007, pp. 91-112. 
SCHICHOR, Yitzhak. Virtual Transnationalism: Uyghur Communities in Europe and The Quest for East Turkestan Independence. Muslim Networks and Transnational Communities in and Across Europe, edited by S. Allievi and J. Nielsen, 281-311. Leiden: E. J. Brill, 2003.

STARR, S. Frederick. Xinjiang: China's Muslim Borderland. Armonk, NY: M.E. Sharpe, 2015.

TODD, Reed J. \& Raschke, Diana. The ETIM: China's Islamic Militants and the Global Terrorist Threat. Westport, Connecticut: Praeger, 2010.

Turkistan News \& Information Network. "Press Release", 8 June 1999.

Wall Street Journal. Ian Johnson. "China Arrests Noted Businesswoman in Crackdown in Muslim Region”. 18 August 1999.

Washington Post. Philip Pan, “In China's West, Ethnic Strife Becomes 'Terrorism'” July 14 2002: A4. 


\section{Studentská sekce}




\title{
Gruzie: od pobřeží Černého moře po vrcholky Kavkazu
}

\begin{abstract}
Albina Iskandarova
Když jsem jela letos poprvé do Gruzie, vůbec jsem nevěděla, co od cesty očekávat. Nakonec mě ale Gruzie jednoznačně nadchla - dobrosrdečnými lidmi, chutným jídlem, mořem i horami. A 21 dní bylo tak málo na to si tam všechno užít. Jako nejlepší a nejlevnější spoj z Prahy je let do města Kutaisi, což je jedno z hlavních historických a ekonomických center západní Gruzie. Vyšla jsem z poměrně starého letiště a první věcí, která mě překvapila, byli toulaví psi. Nyní už je pro mě těžké si Gruzii bez nich představit. Problém pouličních zvířat v Gruzii je řešen lidsky, jsou sterilizováni a s čipem.

S Gruzíny jsem zpočátku mluvila anglicky, ale pak jsem pochopila, že je to zbytečné všichni starší lidé, s kterými jsem mluvila, rozuměli a mluvili rusky. S mladšími lidmi se dalo bez problému domluvit anglicky. Jako Ruska jsem ani jednou neměla žádný problém kvůli napjatým vztahům mezi Ruskem a Gruzií.

Hlavním městem Gruzie je Tbilisi. Ačkoli je země jen o málo menší než Česká republika, celková populace je asi jen 4,6 milionu obyvatel. Nejpočetnější národnostní skupiny jsou Gruzíni, Azerové, Arméni, Osetinci a Rusové.

Obyvatelé Gruzie se považují jednoznačně za Evropany. Je to dáno tím, že ani geograficky není úplně jasné, zda je Gruzie v Asii nebo v Evropě a často se to bere různě. Gruzíni vzhlížejí k Evropské unii, všude mají vyvěšeny vlajky Gruzie společně s vlajkou Evropské unie. To svědčí o tom, že by Gruzíni chtěli vstoupit do EU, ale zatím se jim to nedař́i.
\end{abstract}

\section{Adžárie}

Adžárie je autonomní republikou a nachází se v jihozápadní Gruzii. Je omývaná Černým mořem a zároveň leží na úpatí hor Malého Kavkazu. Hlavním městem je prrístavní město Batumi, které bylo jedním z hlavních turistických měst bývalého Sovětského svazu. I v dnešní Gruzii patř́ mezi hlavní turistická centra. Batumi se považuje za město, kde je největší množství ročních srážek ze všech měst bývalého Sovětského svazu.

Stačí odjet pouze 10 kilometrů od rušného Batumi a ocitla jsem se na jedinečných panenských místech, kterých se civilizace nedotkla. Hory, subtropické lesy a moře, výjimečné 
chráněné území Gruzie - horská Adžárie. Zde jsem obdivovala přírodu, hory, navštívila jsem vodopád Makhuntsetis a most královny Tamary. Tamara Gruzínská je dodnes nejúctyhodnější postavou mezi Gruzíny. Byla to královna Gruzínského království v letech 1184 až 1213. Její jméno je spojeno s jedním z nejlepších období v historii Gruzie.

Největším zážitkem pro mě ale byla návštěva adžárské rodiny. Gruzínská pohostinnost je velmi slavná. Koneckonců, mezi Gruzíny se říká, že host je Pánovým poslem. Z vlastní zkušenosti mohu potvrdit, že Gruzíni jsou nejpohostinnějšími lidé, které jsem v životě potkala.
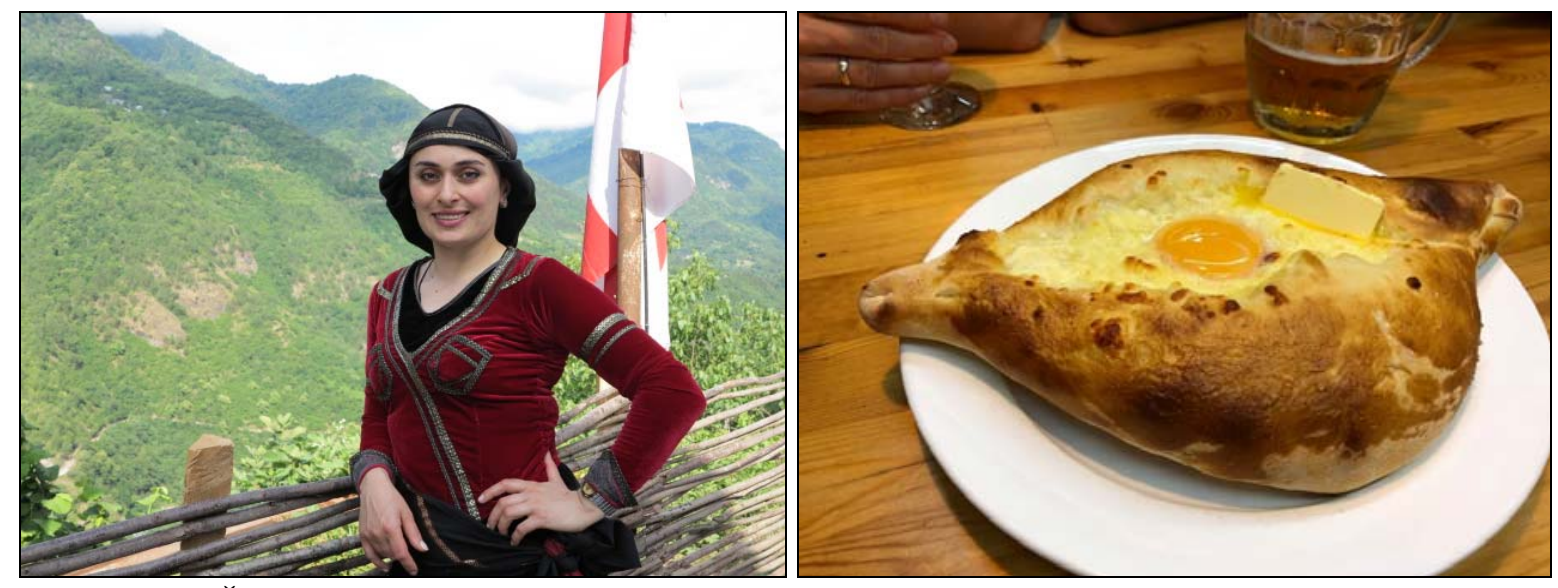

Obrázek 1. - Žena v tradičním adžárkém kroji, vlastní foto

Obrázek 2. - Ačaruli Chačapuri z Adžárie, vlastní foto

Naše hostitelka připravila skutečná adžárská domácí jídla a hostitel pořádal degustaci domácího adžárského vína a domácí pálenky - čači. Gruzíni hrdě vyprávějí o tom, že to byla právě Gruzie, kde víno vůbec vzniklo. Celá hostina probíhala s doprovodem gruzínských národních tanců a živé hudby. Gruzínský proslov před pitím alkoholu je také nedílnou součástí posezení. Hostitel sděluje svoji životní filozofii a zkušenosti, popřeje hodně zdraví, štěstí a lásky všem přítomným. Před ukončením večera se všechny ženy převlékly do tradičních krojů a hostitelé nás učili gruzínským lidovým tancům. Muži a ženy tančí zvlášt', což vysvětluje to, že Gruzíni mají odpradávna výjimečný vztah k ženám. Ženy by tady měly být skromnější a berou se jako slabší jedinci v tom dobrém slova smyslu.

Tato návštěva byla prvním krokem moji zamilovanosti k této zemi.

\section{Svanetie}

Dále jsem navštívila horskou oblast Gruzie - Svanetii, divokou a krásnou zemi Svanů. Hlavními důvody pro návštěvu této oblasti byl můj zájem vidět zasněžené vrcholy Kavkazu nad malebnými údolími, bouřlivými horskými řekami a vysokohorskými loukami. 

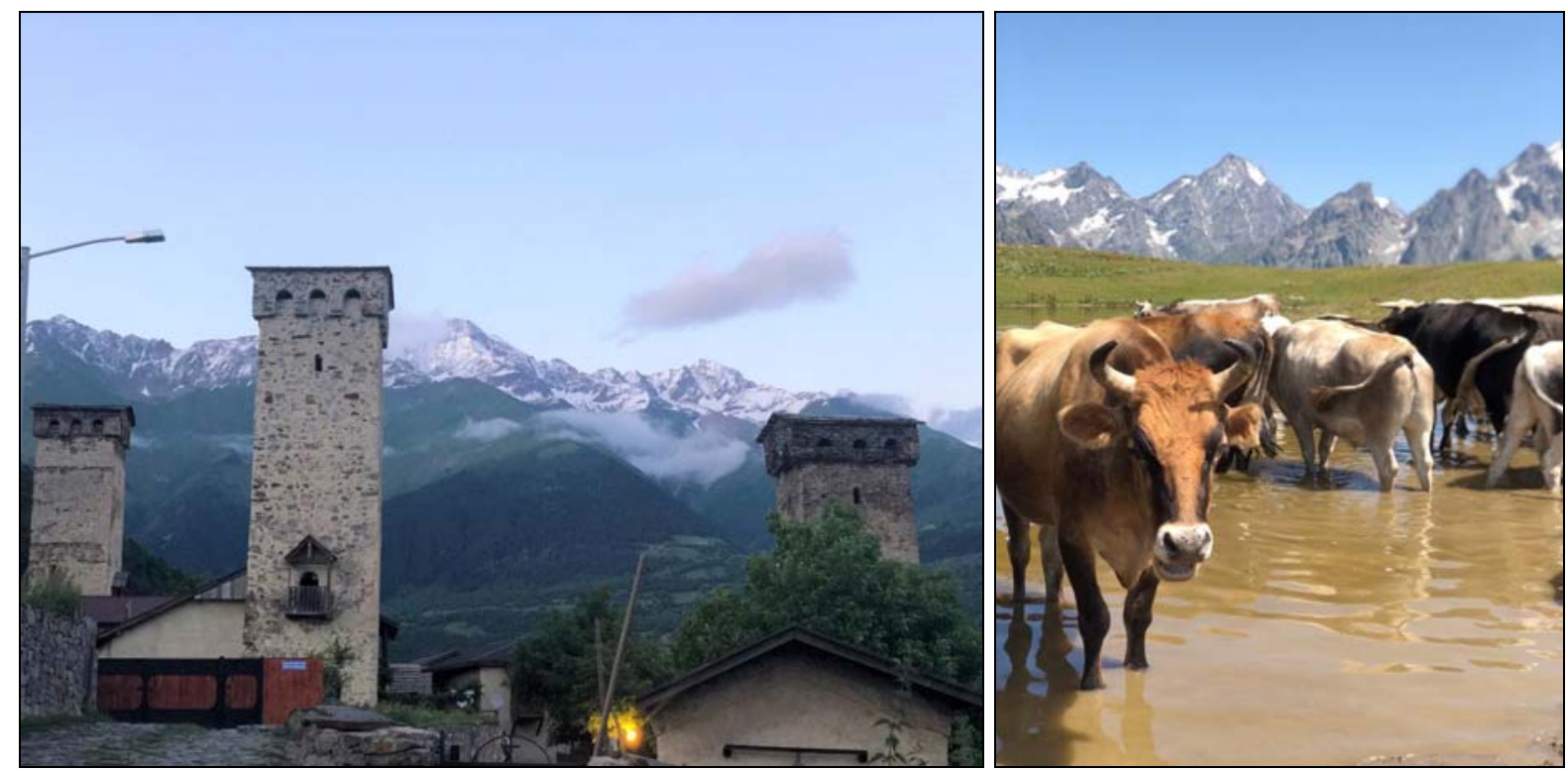

Obrázek 3. - Město Mestia, vlastní foto

Obrázek 4. - H ospodářská zvířata ve Svanetii, vlastní foto

Cesta začala na hlavním nádraží v Batumi, ze kterého jsem se vypravila do Zugdidi. Jako hlavní způsob veřejné dopravy nám posloužila maršrutka, která je stále velmi rozšířená v zemích bývalého Sovětského svazu a na Balkánu.

Pokračovat ze Zugdidi do Mestie veřejnou dopravou není snadné, protože maršrutka odjede až poté, co se auto naplní. Proto je lepší si pronajmout taxi. Na rozdíl od Adžárie se v této oblasti rusky už skoro nemluvilo. Avšak kvůli turismu se i tady dalo domluvit anglicky.

Hlavním cílem této cesty byla vesnice Ušguli. Ušguli je vysokohorská trvale osídlená vesnice, která se nachází v nadmořské výšce 2200 metrů nad mořem a je nejvýše položenou obývanou vesnicí v Evropě, pokud se budeme řadit mezi ty, kteří považují Gruzii za Evropu. V Ušguli dnes žije kolem sedmdesáti rodin, příslušníků jihokavkazského národa Svanů.

Svanetie je obecně drsné místo, po většinu roku je zde chladno, a po většinu zimy je Ušguli izolováno od vnějšího světa sněhovými závějemi. Kvůli klimatu zde nerostou hrozny a Svanové tedy nepěstují víno. Pijí však vlastní pálenku - araku, vyrobenou z jablek nebo medu.

Ušguli se považuje za nejnepřístupnější kout obydlené Svanetie - i proto není snadné se dostat z Mestie do Ušguli. Celá potíž spočívá v tom, že do Ušguli silnice, tak jak je obvykle chápeme, chybí. Spíše než o silnici se jedná pouze horská cesta. Abychom př̌konali vzdálenost $46 \mathrm{~km}$, museli jsme strávit asi tři hodiny v autě.

Ale stálo to za to! Dechberoucí je výhled na nejvyšší gruzínskou horu Šcharu s výškou hlavního vrcholu $5201 \mathrm{~m}$. 


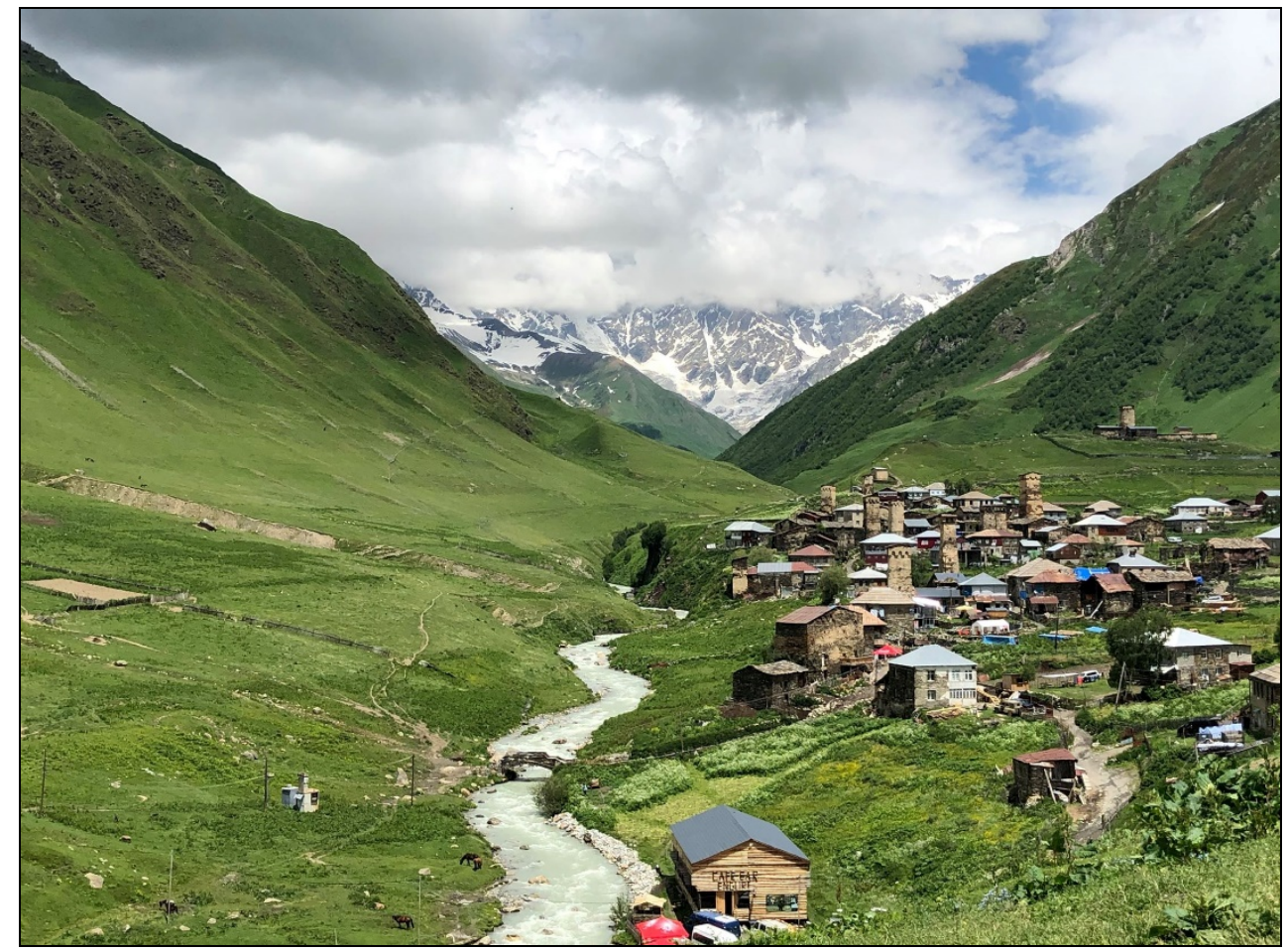

Obrázek 5. - Vesnice Ušguli, vlastní foto

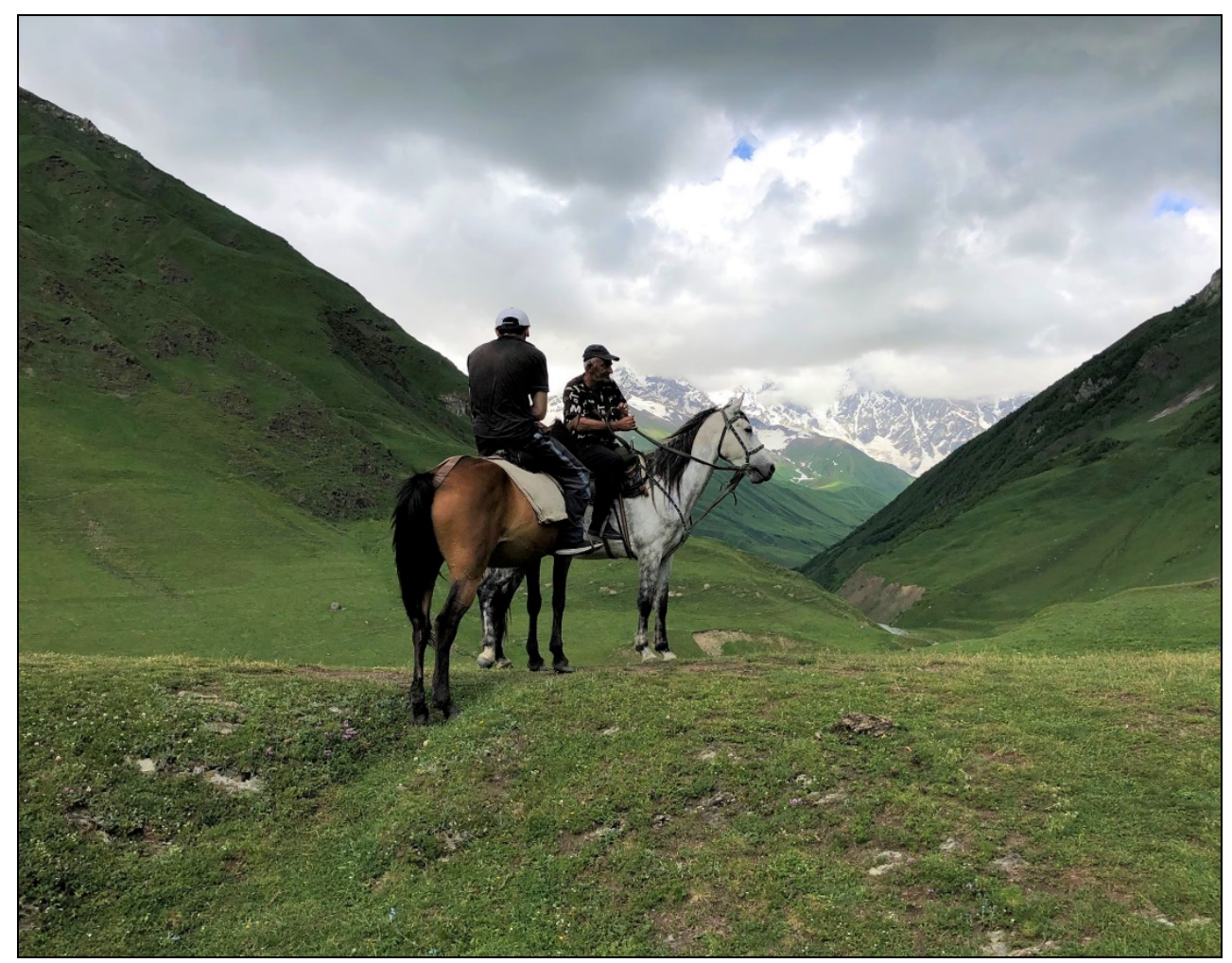

Obrázek 6. - Jezdci v Ušguli, zdroj: vlastní foto

\section{Svanové}

Obyvatele této vesnice - Svanové - jsou často světlovlasí a vysocí lidé s modrýma očima, což je pro většinu Gruzínů atypické. Podle jedné verze jsou Svanové potomci evropských rytiřru, kteří kdysi sloužili ve službách gruzínských králů. 
Svanové jsou pravoslavní křest’ané. Zároveň si však Svanové zachovali mnoho pohanských zvyků. Např́íklad starověký festival Lamprob je průvodem nočních svítilen, ve kterém jde každý muž z vesnice a drží v ruce hořící pochodeň.

Svanové si do našich dnů dochovali zvyky související s krevní mstou. Za vraždu jednoho muže se jeho příbuzní následně brutálně pomstí všem mužům klanu vraha. Symbolem regionu jsou svanetské věže. Velké věže z vysokých kamenů, z nichž mnohé byly postaveny před tisíci lety, to je jeden z hlavních zázraků, pro které turisté do Svanetie přicházejí. Věž má tři až pět pater. První patro - bez oken a mezer - je chlév pro hospodářská zvířata. Druhé patro je typicky obytné. A patro třetí je obranné - sem se během obléhání uchylovala rodina do bezpečí. Některé věže jsou obytné, jiné jsou strážní věže a v některých jsou zásoby. Dnes jsou některé věže přeměněny na turistické restaurace - zde můžete stolovat př́mo na střeše a obdivovat krásy okolí.

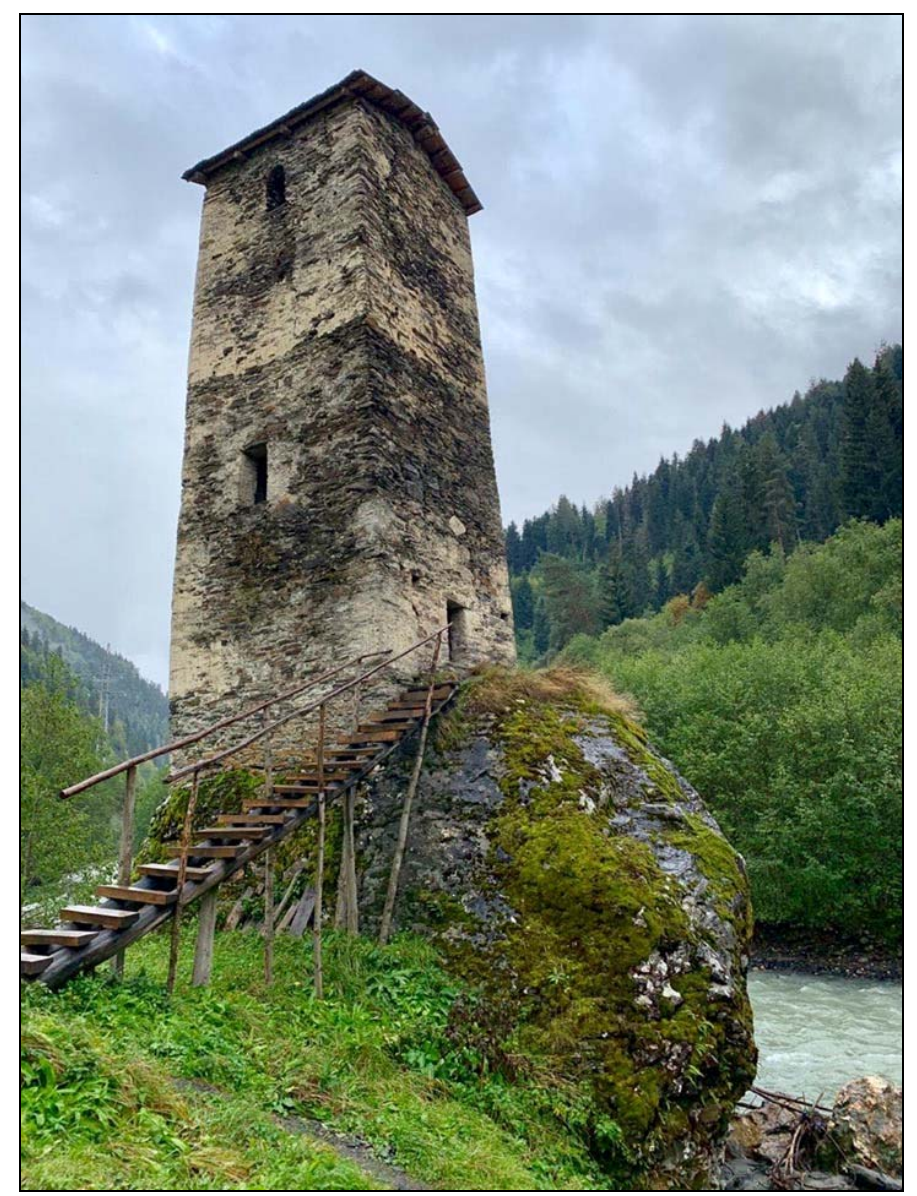

Obrázek 7. - Svanetská věž, vlastní foto

O Svanech najdete na internetu poměrně málo informaci. Tento národ je výjimečný, mají unikátní tradice a styl života. Proto jakmile jsem z Gruzie odletěla zpět do Prahy, už jsem věděla, že se tam určitě vrátím, a to především kvůli Svanetii a Svanům. 


\section{Letní škola v Indii}

Tereza Braunsbergerová, Andrea Černá, Michaela Kotrbatá, Nela Riegerová

Indie, druhá nejlidnatější země světa. Země, kterou jsme měly šanci navštívit díky letní škole, a do konce života na tuto zkušenost nezapomeneme. Tři blondýny a jedna zrzka se vydaly poznávat jiný svět. Ani jeden den ze šesti týdnů nebyl obyčejným. Před odletem jsme byly ze všech stran varovány před nejrůznějšími nástrahami této země. Z vyprávění jsme očekávaly nepř́ijemný zápach, který nás omráčí hned při výstupu z letiště. Obávaly jsme se také častých krádeží či mužského obtěžování. Naštěstí jsme se ani s jedním případem nesetkaly. Poprvé v životě jsme se cítily jako hollywoodské hvězdy. Při každém kroku jsme byly doslova obklopeny místními. Zírali na nás jako na nadpozemské bytosti. Toužili se s námi dát do řeči nebo nám alespoň podat ruku a udělat selfie. Při fotografování se často tvořily fronty, ze kterých bylo téměř nemožné uniknout.

Prvním šokem byla místní doprava. Pro nás, kteří jsme zvyklí na přechody a dopravu, co má řád, to byl pěkný oříšek. Vychytat správný okamžik, kdy vkročit do naprosto přeplněné silnice aut, rikš, motorek, krav a psů bylo zpočátku nad naše síly. Při pohledu na takové množství krav nás napadala otázka: „Kde se jich tady tolik vzalo?“ Krávy nebo spíše býci nemají svůj domov kvůli technickému pokroku a jejich nepotřebnosti v zemědělství, a tak jsou ponecháni jejich vlastnímu osudu na ulicích. Pokud se chcete někam dopravit, vybavte se silným klaksonem, protože právě hlasitost troubení udává přednost $\mathrm{v}$ jízdě a nejen to. Klaksonem Indové zdraví protijedoucí, dávají znamení při vjezdu do zatáčky či zastrašují krávy na vozovce.

Tři týdny ve městě Bhubaneswar nám dokázalo, že darovat někomu věc bez návodu k použití nemá vůbec smysl. Město bylo totiž navrženo německým architektem, který zde zavedl západní infrastrukturu, kterou ale místní využívají takříkajíc po svém. Nalezneme zde funkční semafory i přechody, které však nikdo nerespektuje. V Bhubaneswaru, jednom z nejchudších měst Indie, nás jeden z místních pozval k sobě domů. Po počátečních obavách jsme jeho pozvání přijaly a nelitovaly jsme. Při procházení postranními uličkami jsme poprvé spatřily opravdovou chudobu. Dětem hrajícím si na smetišti jsme rozdávaly bonbóny a nevěřícně jsme hleděly kolem sebe. Najednou byl svět kolem nás něco nepředstavitelného. Něco, co se zdá absolutně nereálné. 

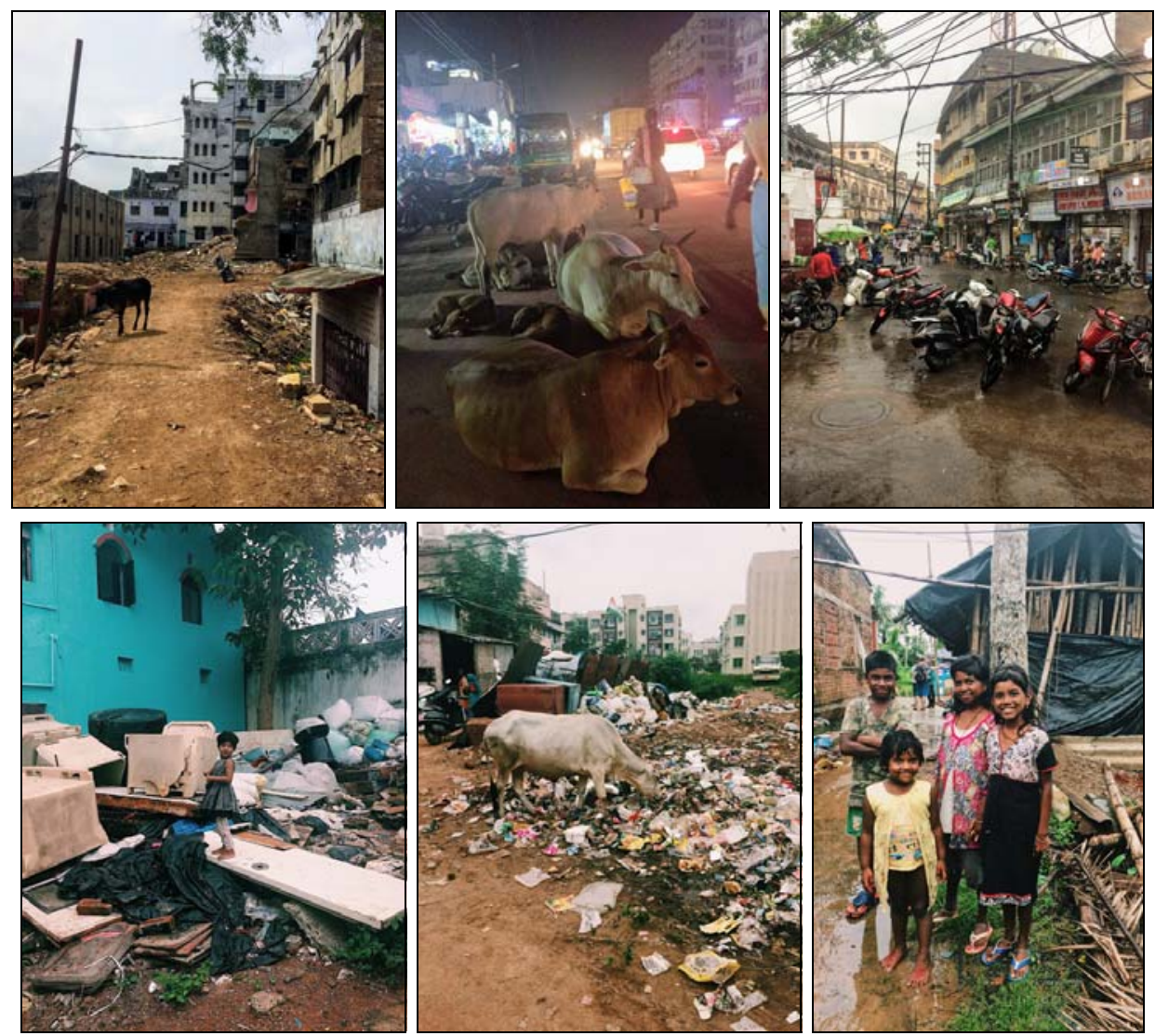

Měly jsme možnost být svědky pohřebních obřadů ve Váránasí. Hinduisté berou smrt zcela odlišně. Smrt v této kultuře nepředstavuje nic negativního, ba naopak. Indové nachází ve smrti naději lepšího života, díky dosažení samsáry, neboli znovuzrození. Každý hinduista touží být pohřben ve Váránasí do posvátné řeky Gangy. Ta zaručuje zbavení všech hříchů a dosažení mokši.
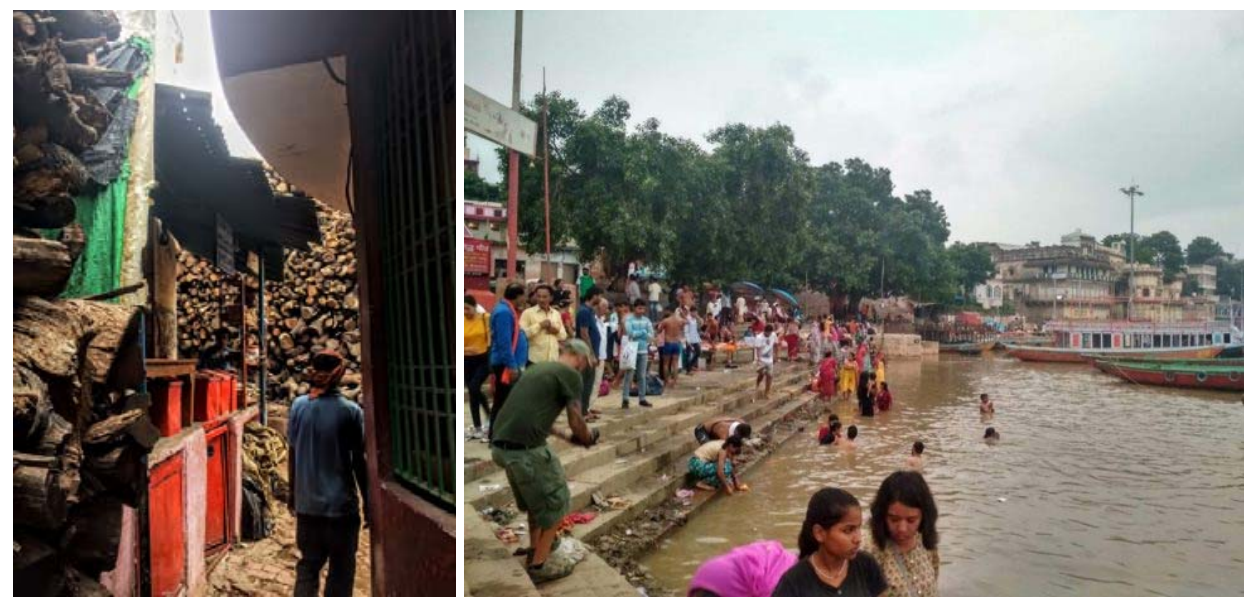

Váránasí, místo, kde je každý den spáleno přes 400 lidí. Rodiny sem převážejí zesnulé i několik dní a dokážou se kvůli obřadu zadlužit na zbytek života. To vše jen kvůli posvátné Ganze, ve které provádí poslední koupel zesnulého a následně do ní vhazují i jeho ostatky. 
Pokud ale zemře těhotná žena, svatý muž, dítě do 12 let, člověk uštknutý hadem či postižený leprou vhazují do řeky tělo bez kremace. Do řeky jsou rovněž vhazovány posvátné krávy. Váránasí je místo, kde se střetává hinduismus s islámem a dalšími náboženstvími. I přes odlišnosti v jednotlivých vírách se zde navzájem tolerují.

Po Váránasí naše cesty vedly do Jaipuru, kterému se přezdívá růžové město. Budovy v tomto městě byly přetřeny $\mathrm{v}$ minulosti na růžovo jako pocta návštěvy britského krále. Jaipur bylo ideálním místem pro nákup typických šperků, oděvů i pokrmů. Obchůdky se nacházely blízko sebe a každý z nich měl své číslo pro lepší orientaci při nákupech. Dále jsme se vydaly do Agry, města, ve kterém se nachází jeden ze sedmi divů světa. Z našeho pohledu si toto označení Taj Mahal zaslouží opravdu právem. Z Agry si odnášíme velký zážitek. Po přistání jsme z letiště jely místním autobusem blíže do centra. Hned po vystoupení se k nám seběhly davy taxikářů a předháněly se, kdo nás odveze. Taxikář, se kterým jsme jezdily nakonec po celou dobu našeho pobytu v Agře, se stal zároveň i naším průvodcem. Jedna z nás v Agře onemocněla a právě „náś“ taxikář byl ten, kdo ji dovezl do nemocnice, pomohl jí vše vyřídit, šel s ní až do ordinace a dokonce jí několikrát opakoval, jak správně brát všechny léky. Tento Ind nás odvezl z Agry do Dillí, odkud jsme se ze zalidněných a horkých měst vydaly do horských oblastí.
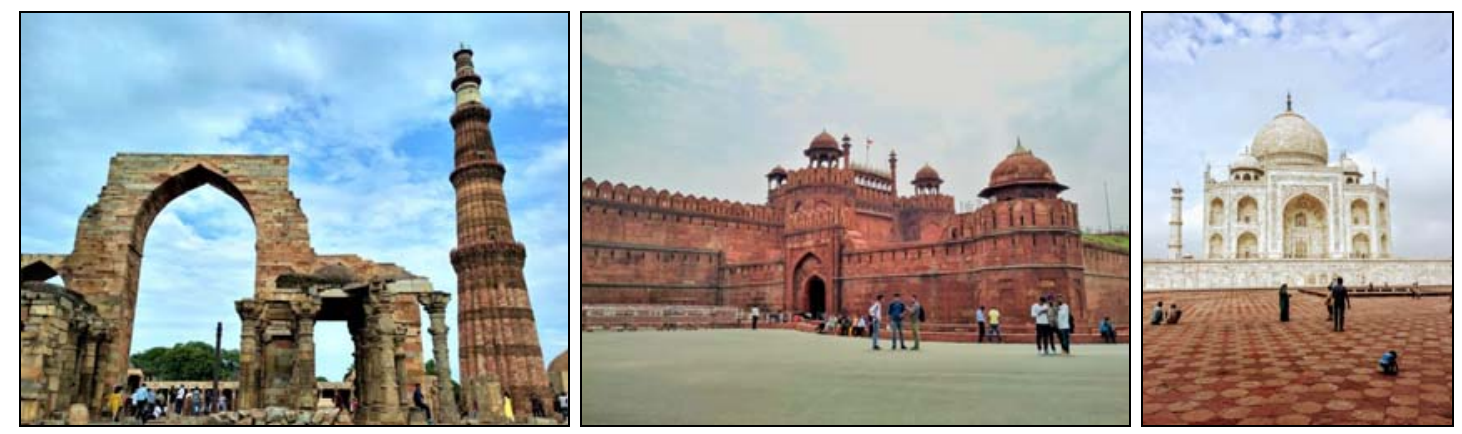

Vrtulákem se z Dillí přesouváme do severní Indie, konkrétně do oblasti McLeod Ganj, jenž je takovým předměstím Dharamsaly. Tato oblast je pro nás naprosto odlišná od ostatních míst, které jsme již v této zemi mohly vidět. Najednou jsme se ocitly v oáze klidu, obklopeni Himalájemi, modlitebními vlaječkami poletujícími si vzduchem a spoustou usmívajících se mnichů v červených hábitech procházejících se kolem. Tato oblast je totiž již od počátku 60 . let tohoto století sídlem exilové vlády Tibetu s oficiálním bydlištěm samotného Dalajlámy, kterého do této oblasti následovalo tisíce tibetských uprchlíků, kteří zde vytvořili již velmi značnou komunitu. 

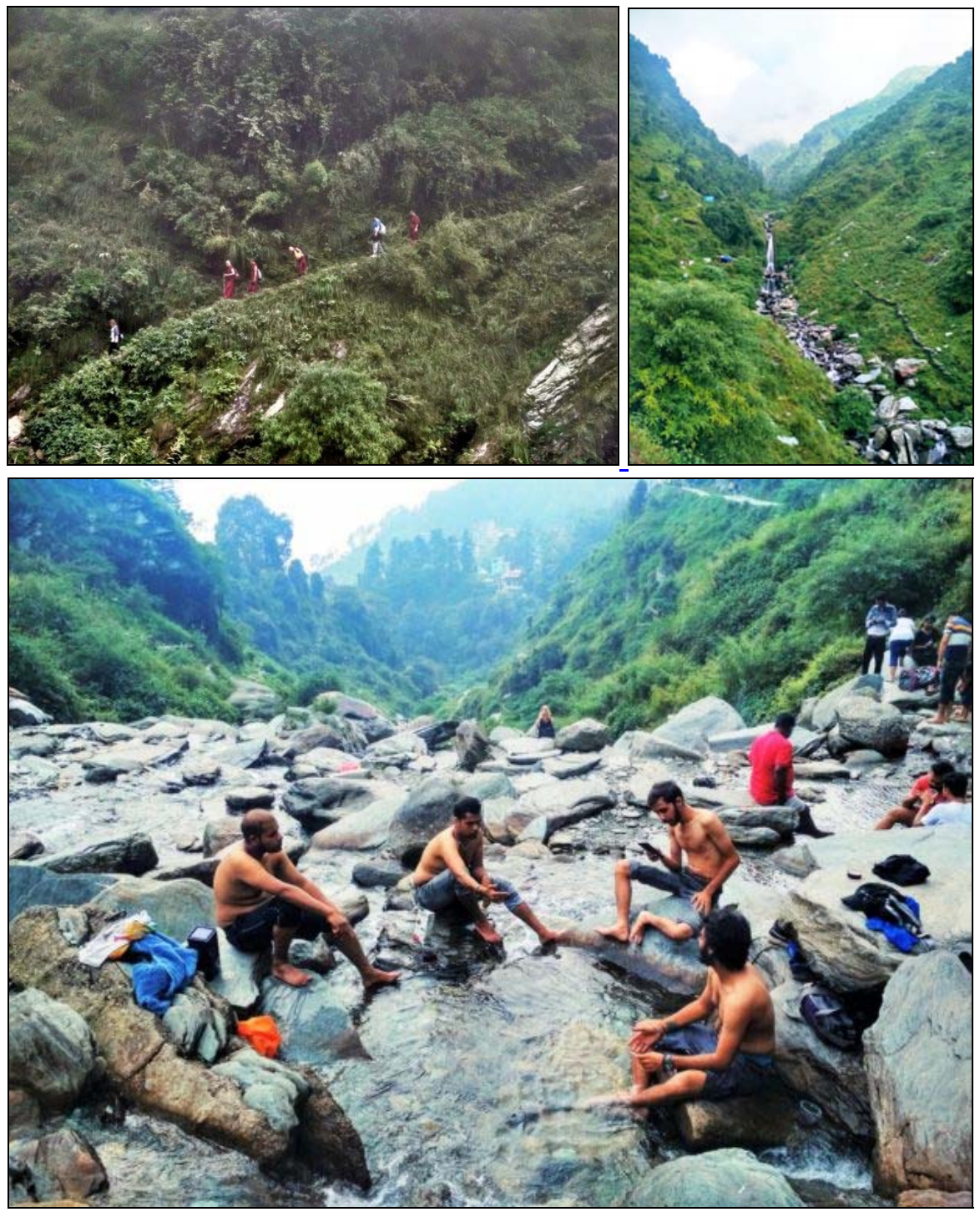

McLeod Ganj se sice nerozléhá na velkém území, ale nabídl nám toho mnoho. Užívaly jsme si několikahodinovou ranní jógu s výhledem na Himaláje, které byly zahaleny mlhou, ale stále si uchovávaly své kouzlo a hlavně tajuplnost. Po tomto našem ranním rituálu jsme se vydávaly objevovat přírodní a kulturní krásy, které oblast nabízela. Z počátku jsme navštívily vodopády a čajové plantáže, a poté jsme se zaměřily na místní kulturu. Ta se zabývala především kulturou tibetskou, avšak byl zde k nalezení i křest’anský kostel. Jedna z našich prvních cest vedla do tibetské dětské vesničky, která funguje jako vzdělávací komunita pro chudé děti, žijící v tomto exilu či tibetské uprchlíky, kterých každoročně přibývá. Těmto dětem je ve vesničce poskytováno vzdělání, výuka tibetštiny, tradic, tanců a celkové tibetské kultury. Děti se ale musí naučit i samostatnosti v podobě vaření nebo úklidu. $\mathrm{K}$ našemu překvapení jsme si návštěvu naplánovaly tak, že se zde zrovna konala školní besídka. Děti různých věkových skupin zde tancují a zpívají ve svých tradičních oděvech. 

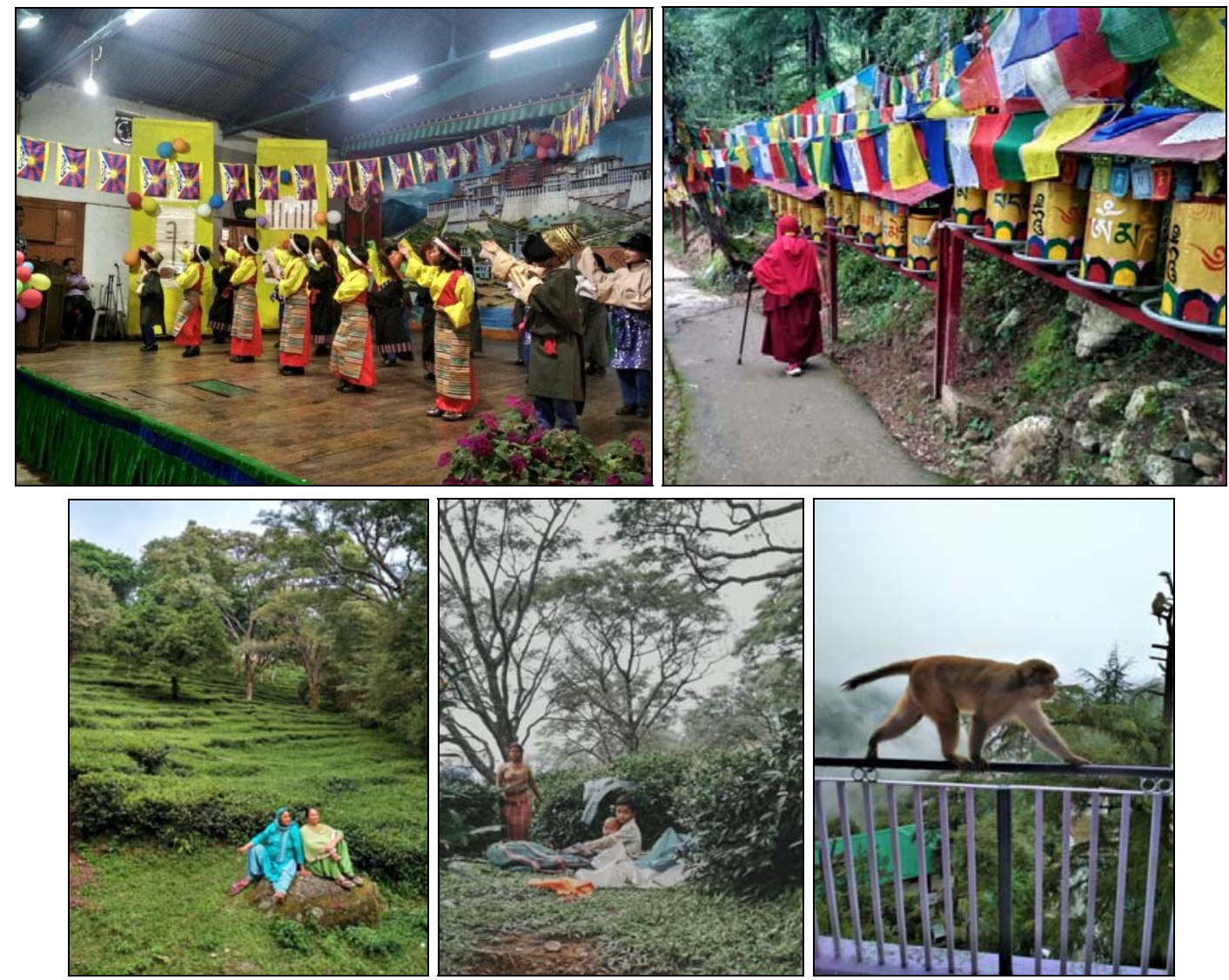

Nemohly jsme zde vynechat ani chrámový komplex Tsuglagkhang, kde se nachází mimo jiné i sídlo Dalajlámy. Zde jsme byly př́tomny u debat mezi mnichy, doprovázené neustálým smíchem a tleskání do dlaní. Prohlídly jsme si místní chrám, zachráněné artefakty z Tibetu i pozlacenou sochu Buddhy. $\mathrm{V}$ areálu se také nachází muzeum, které se věnuje období převážně od čínské anexe Tibetu až po současnou situaci. Mnozí obyvatele tuto situaci řeší nebo na ni upozorňují skrze obětování, a to na veřejných místech formou sebeupálení.

Po lehké ochutnávce Tibetu se vydáváme zpět do Dillí, tentokrát již autobusem. Cesta trvala necelých deset hodin. Nebyla nijak náročná, jelikož se jelo přes noc a dá se říct, že velmi rychle utekla. Utekla dokonce tak rychle, že jsme si nestihly zamluvit ani žádné ubytování v Dillí, jak jsme plánovaly. Ocitly jsme se tedy v půl páté ráno u hlavní silnice v Dillí, obklopeny taxikáři, kteří jen čekali, kterou adresu jim sdělíme. Naštěstí Dillí je obrovské město se spoustou hotelů. V jednom z nich se nacházeli i naši přátelé z letní školy, ke kterým jsme se rozhodly připojit.

Hned na začátek se v Dillí konal jeden z „tisícư“ hinduistických svátků doprovázený bubny, průvody a nabarvenými krávami, které za sebou táhly vozíky s hinduistickým božstvem. Naše kroky však směřovaly ke Qutub Minar, nejvyššímu minaretu Indie, který je částečně postaven ze zničených hinduistických staveb. 


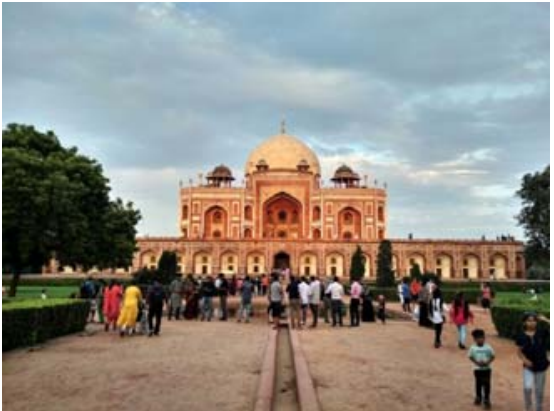

Dále jsme navštívily Humájúnovu hrobku, která byla inspirací pro stavbu samotného Taj Mahalu. Podobnost je velmi zřetelná. Tato stavba má však červenou barvu, nachází se zde i více hrobek a k naší radosti méně turistů. Neodolaly jsme ani slavné pevnosti Red Fort, která nás popravdě zklamala. Během naší cesty jsme navštívily i jiné pevnosti a bohužel Red Fort byla spíše slabším zážitkem.

Během našeho pobytu jsme se čím dál tím více otrkávaly, takže už ani smlouvání nám nedělalo takové problémy jako z počátku. Často bývalo náročné odhadnout reálnou cenu. Indové dávají turistům rádi přirážky, a to klidně i stoprocentní. Ve výsledku člověk zjistí, že se dohaduje pouze o pár korun. Avšak princip, že máme platit více jen kvůli tomu, že jsme turistky, se nám zkrátka nelíbil. Poslední den nám proto s nákupem suvenýrů pomáhali místní Indové. Ceny domluvili během chvilky bez větších dohadů. Na závěr dne nás pozvali do skvělé restaurace, kde jsme mohly ochutnat tradiční indické pokrmy i se spoustou sladkostí. Nebudeme si nic nalhávat. Už jsme se nemohly dočkat evropské kuchyně, poněvadž indické jídlo je velice ostré a kořeněné.

Tato cesta $\mathrm{v}$ nás zanechala mnoho. Indie je nádherná země, kde je člověk v úžasu každý den. Její rozmanitost nezná konců a člověka nepřestane fascinovat. V této zemi, kde se ve velké míře objevuje chudoba, jsme se po celou dobu nesetkaly s žádnými problémy, které by nám cestu znepř́ijemňovaly. Lidé i přes to vše byli velmi milí a ochotní nám $v$ každé situaci pomoci. Tato zkušenost byla v každém př́padě $\mathrm{k}$ nezaplacení. Nejen že jsme mohly poznat jednu z našich nejstarších kultur, ale také jsme si mohly uvědomit, v jak velkém blahobytu žijeme a jakými malichernostmi se často zaobíráme $\mathrm{v}$ porovnání $\mathrm{s}$ některými obyvateli této země. Získané zkušenosti jsou nepopsatelné a kdykoliv bychom šly do této výzvy znovu. Indie je země kulturně zcela jiná, odlišná a tím krásná. Indie, děkujeme za lidskou obětavost, se kterou jsme se zde setkaly, za nové přátele, poznatky a obohacení našich životů. 


\section{Obsah}

Recenzované články:

EVROPSKÝ NÁROD VS. GLOBALIZOVANÝ NACIONALISMUS

Miroslav Hroch DOI: https://dx.doi.org/10.7160/KS.2021.150101...

ETNICKÁ IDENTITA URUGUAYCŮ

Anna Josková DOI: https://dx.doi.org/10.7160/KS.2021.150102

MEZIETNICKÝ A OBČANSKÝ ASPEKT OSLAV STÁTNÍCH SVÁTKŮ V KYRGYZSTÁNU

Zhyldyz Kaarbaeva DOI: https://doi.org/10.7160/KS.2021.160103 48

FORMOVANIE KULTÚRNEJ A ETNICKEJ IDENTITY MAORIOV PROSTREDNÍCTVOM PRÍSLUŠNOSTI KU GANGU

Lucia Bistárová DOI: https://dx.doi.org/10.7160/KS.2021.150104. 61

THE XINJIANG UYGHUR AUTONOMOUS REGION AS AN EXAMPLE OF SEPARATISM IN CHINA

Dru C. Gladney DOI: https://dx.doi.org/10.7160/KS.2021.150105 85

Studentská sekce:

GRUZIE: OD POBŘEŽÍ ČERNÉHO MOŘE PO VRCHOLKY KAVKAZU 106 